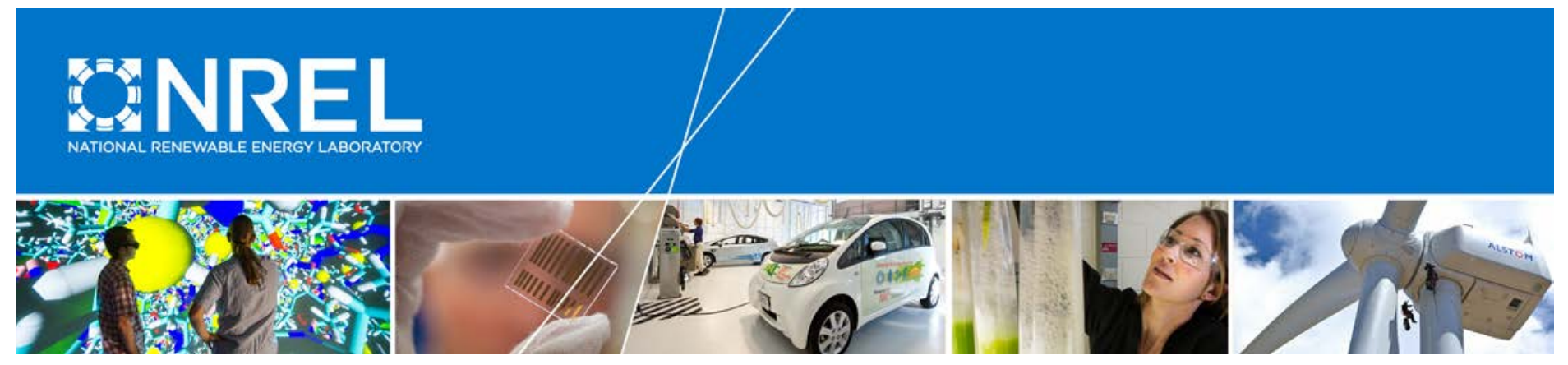

\title{
U.S. Department of Energy Regional Resource Centers Report: State of the Wind Industry in the Regions
}

Ruth Baranowski, Frank Oteri, lan Baring-Gould, and Suzanne Tegen National Renewable Energy Laboratory

NREL is a national laboratory of the U.S. Department of Energy Office of Energy Efficiency \& Renewable Energy Operated by the Alliance for Sustainable Energy, LLC

This report is available at no cost from the National Renewable Energy Laboratory (NREL) at www.nrel.gov/publications.

Technical Report

NREL/TP-5000-62942

March 2016 


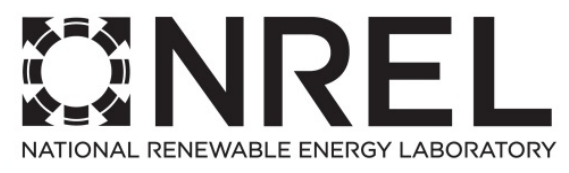

\title{
U.S. Department of Energy Regional Resource Centers Report: State of the Wind Industry in the Regions
}

\author{
Ruth Baranowski, Frank Oteri, \\ lan Baring-Gould, and Suzanne Tegen \\ National Renewable Energy Laboratory
}

Prepared under Task No. WE14.BB01

NREL is a national laboratory of the U.S. Department of Energy Office of Energy Efficiency \& Renewable Energy Operated by the Alliance for Sustainable Energy, LLC

This report is available at no cost from the National Renewable Energy Laboratory (NREL) at www.nrel.gov/publications.

National Renewable Energy Laboratory 15013 Denver West Parkway Golden, CO 80401 303-275-3000 • www.nrel.gov
Technical Report

NREL/TP-5000-62942

March 2016

Contract No. DE-AC36-08GO28308 


\section{NOTICE}

This report was prepared as an account of work sponsored by an agency of the United States government. Neither the United States government nor any agency thereof, nor any of their employees, makes any warranty, express or implied, or assumes any legal liability or responsibility for the accuracy, completeness, or usefulness of any information, apparatus, product, or process disclosed, or represents that its use would not infringe privately owned rights. Reference herein to any specific commercial product, process, or service by trade name, trademark, manufacturer, or otherwise does not necessarily constitute or imply its endorsement, recommendation, or favoring by the United States government or any agency thereof. The views and opinions of authors expressed herein do not necessarily state or reflect those of the United States government or any agency thereof.

This report is available at no cost from the National Renewable Energy Laboratory (NREL) at www.nrel.gov/publications.

Available electronically at SciTech Connect http:/www.osti.gov/scitech

Available for a processing fee to U.S. Department of Energy and its contractors, in paper, from:

U.S. Department of Energy

Office of Scientific and Technical Information

P.O. Box 62

Oak Ridge, TN 37831-0062

OSTI http://www.osti.gov

Phone: 865.576.8401

Fax: 865.576.5728

Email: reports@osti.gov

Available for sale to the public, in paper, from:

U.S. Department of Commerce

National Technical Information Service

5301 Shawnee Road

Alexandria, VA 22312

NTIS http://www.ntis.gov

Phone: 800.553 .6847 or 703.605 .6000

Fax: 703.605.6900

Email: orders@ntis.gov 


\section{Acknowledgments}

The authors wish to thank the U.S. Department of Energy Wind and Water Power Technologies Office for funding the Regional Resource Centers, this report, and broader stakeholder engagement and education efforts, including the WINDExchange initiative. Thanks also to Patrick Gilman, Maggie Yancey, and Amber Passmore for their leadership and support.

Thanks to the Regional Resource Centers for their work and contributions to this document:

- Four Corners Wind Resource Center: Sarah Cottrell Propst, Meghan Dutton, Rebecca Nelson, Amanda Ormond, Karin Wadsack, Sarah Wright

- Islanded Grid Resource Center: Suzanne MacDonald, Stephanie Nowers, Chris Rose, Brooks Winner

- Midwest Wind Energy Center: Lisa Daniels, Karen Majewicz, Tom Wind

- Northeast Wind Resource Center: Maria Blais Costello, Deborah Donovan, Warren Leon, Val Stori, Anthony Vargo, Paul Williamson

- Northwest Wind Resource and Action Center: Mia Devine, Jennifer Grove, Julie Peacock, Rachel Shimshak, David Wolf

- Southeast Wind Energy Resource Center: Jen Banks, Mary Hallisey Hunt, Katharine Kollins, Jon Miles.

Thanks to individuals from the National Renewable Energy Laboratory who reviewed the report (Dave Corbus and Brian Smith), provided input (Robi Robichaud), and work behind the scenes to support the Regional Resource Centers project and its many aspects (Corrie Christol and Julie Jones).

The authors also wish to thank the following individuals and organizations for their contributions to this report: Bruce Burcat, Mid-Atlantic Renewable Energy Coalition; Mike Kostrzewa, Colorado State University; Kylah McNabb, Oklahoma Department of Commerce; Ruth Douglas Miller, Kansas State University; Dan McGuire, McGuire Consulting; Nancy Rader, CalWEA; Remy Pangle, James Madison University; Susan Stewart, Pennsylvania State University; Rich Stromberg, Alaska Energy Authority; Brent Summerville, Appalachian State University; Heather Thomson, Mid-Atlantic Renewable Energy Coalition; and Michael Twedt, South Dakota State University. 


$\begin{array}{ll}\text { List of Abbreviations and Acronyms } \\ \text { 4CWRC } & \text { Four Corners Wind Resource Center } \\ \text { BOEM } & \text { Bureau of Ocean Energy Management } \\ \text { CNMI } & \text { Commonwealth of the Northern Mariana Islands } \\ \text { CREP } & \text { Community Renewable Energy Project } \\ \text { DOE } & \text { U.S. Department of Energy } \\ \text { MW } & \text { megawatt } \\ \text { MWEC } & \text { Midwest Wind Energy Center } \\ \text { NREL } & \text { National Renewable Energy Laboratory } \\ \text { NWRC } & \text { Northeast Wind Resource Center } \\ \text { PURPA } & \text { Public Utility Regulatory Policies Act } \\ \text { RPS } & \text { renewable portfolio standard } \\ \text { RRC } & \text { Regional Resource Center } \\ \text { SWERC } & \text { Southeast Wind Energy Resource Center }\end{array}$




\section{Executive Summary}

Significant expansion of wind energy deployment will be required to achieve the President's goal of doubling renewable energy production in the United States by 2020. Wind energy currently provides more than $4 \%$ of the nation's electricity but has the potential to provide much more. In 2014, the U.S. Department of Energy (DOE) established six wind Regional Resource Centers (RRCs) to provide information about wind energy, focusing on regional qualities.

The wind industry and DOE are addressing technical challenges to increasing wind energy's contribution to the national grid (such as reducing turbine costs and increasing energy production and reliability), and they recognize that public acceptance issues can be challenges for wind energy deployment. Wind project development decisions are best made using unbiased information about the benefits and impacts of wind energy. Well-informed decision-makers and communities are better prepared to navigate the sometimes contentious development process, maximizing the benefits experienced while reducing potentially negative impacts when deploying wind in their regions. Expanding the nation's wind energy portfolio requires highimpact, regionally specific strategies to inform the policy and permitting processes and improve public discourse, thereby reducing conflict around deployment decisions and ultimately increasing the annual rate of wind deployment.

This document summarizes the status and drivers for U.S. wind energy development on regional and state levels. It is intended to be a companion to DOE's 2014 Distributed Wind Market Report (U.S. DOE 2015a), 2014 Wind Technologies Market Report (U.S. DOE 2015b), and 2014 Offshore Wind Market and Economic Analysis (Navigant 2014) that provide assessments of the national wind markets for each of these technologies. Figure ES.1 shows the installed capacity of wind energy in the United States as of December 2015.

The RRCs have identified a wide array of market challenges that continue to hinder wider-scale deployments of wind technologies. Highlighted by region in the following sections, these issues include:

- Insufficient transmission capacity and the need for transmission improvements

- Energy market modifications (such as more liquid bilateral markets for integration resources, 15-minute scheduling, and development of regional energy imbalance markets)

- Lack of local wind siting or zoning ordinances; ordinances that do not reflect best practices or do not allow the flexibility in wind development to address small, distributed, community, or utility-scale wind projects

- Integration challenges and costs

- Lack of clear federal policy

- Need for public education and engagement of wind siting issues, exacerbated by misinformation and negative public opinion regarding wind energy 
- Poor understanding of wind energy's economic impacts, including local tax benefits, jobs and economic development, and turbine manufacturing

- State and regional competition

- Challenges with development on federal and native lands

- Need to advance the state-of-the-art in power sector resource planning processes, ensuring that accurate wind information is utilized in utility integrated resource and state-based clean energy planning

- Need for science-based resource planning in siting guidelines, especially for development in sage grouse and other environmentally sensitive areas

- Restricted access to capital; limited financing, funding, and technical assistance for small/community/distributed wind development

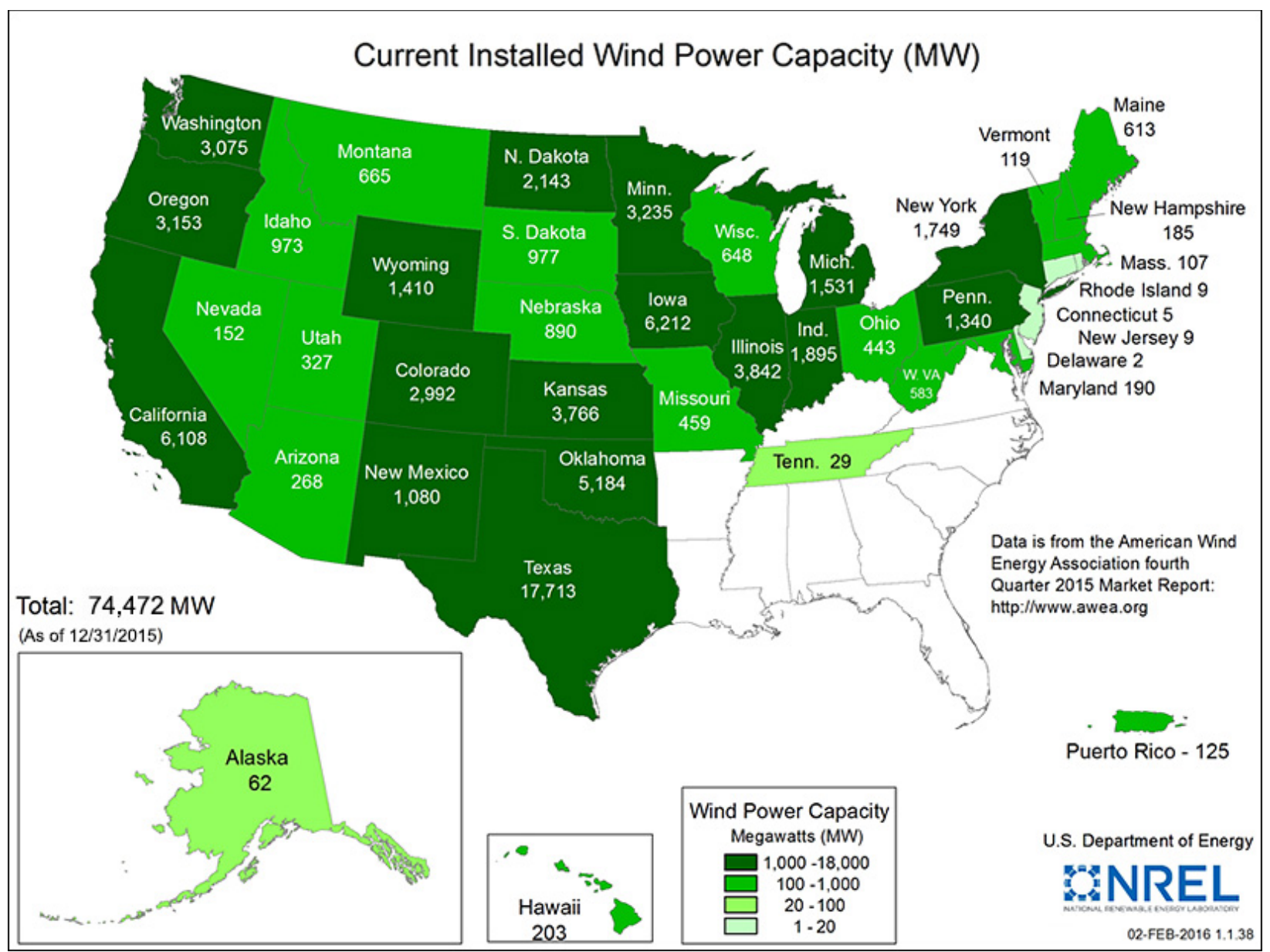

Figure ES-1. Installed wind capacity in the United States as of December 2015

- The high costs of offshore wind energy, lack of independent information and outreach geared toward innovative regional procurement targets, attracting financing, alternative financing mechanisms, and regional supply chain development 
- Complexity of the offshore wind regulatory process; addressing technical issues related to installation, interconnection, and operation; researching and mitigating environmental impacts; interacting with other human uses; and public acceptance of offshore wind

- The fact that there are no full-scale offshore wind turbines currently deployed in the United States, leading to an inability to build credibility around the market opportunity.

Focused primarily on isolated, islanded power systems in Alaska, coastal New England, and the Territories of the United States, the Islanded Grid Resource Center identified additional distinct challenges unique to their situation. The primary development challenge in their region: the upfront cost of deploying a sophisticated wind-diesel system in an isolated, remote, or islanded area with relatively low technical and human capacity. Since most of these islanded power grids are located a distance away from the road system, transportation and mobilization costs are much higher than they are for communities in other regions on the road system. Besides transportation and mobilization, another challenging cost driver is scale.

There are several wind energy development challenges for large islanded grids in the Railbelt transmission system ${ }^{1}$ in Alaska. They include the region's heavy dependence on natural gas-fired power; the risk-adverse nature of the six utilities serving the region, which prevents them from accepting wind energy; a relatively weak, inflexible grid that makes it more difficult to integrate wind power; lack of clear regulatory policy that defines the rules of engagement between those utilities and independent power producers that wish to develop wind; lack of a universal transmission tariff; lack of any regional generation and transmission planning; and lack of any regional transmission organization or independent system operator.

In general the goal of the RRCs is to make it easier for stakeholders and decision-makers to decide whether responsible and appropriate wind project development is right for their communities by producing relevant, actionable, and fact-based information and to deliver that information in useful forms to those who need it when they need it.

In their first year, the DOE's RRCs have had a tremendous impact on key stakeholders, engaging them in wind power issues in their communities and regions. The RRCs reported more than 22,000 touches with key stakeholders and have positively "engaged" more than 12,600 people, moving them toward wind power acceptance as a viable option to address the nation's long-term energy needs. Engagements were typically made through events such as meetings with identified stakeholders, interactive webinars, workshops, tours, and presentations at topical regional conferences. Additional efforts were undertaken through outreach products such as handouts, meeting materials, and newsletters, while direct engagement with regional media organizations was also supported. In total, more than 1.2 million people were identified as being reached by RRC outreach efforts. More targeted efforts ensured that key stakeholders received information that allowed them to include wind technology in plans or policies that had either not included wind or that included outdated wind information.

In addition to outreach activities to provide science-based information to key stakeholders, several RRC projects are underway that may help support expanded wind development. These include:

\footnotetext{
${ }^{1}$ A small, isolated transmission system in Alaska that covers the state's population centers along the main railroad line, including the Seward, the Kenai, Anchorage, Wasilla, and north to Fairbanks.
} 
- The Northeast Wind Resource Center developed web-based information resources and a set of evaluation criteria that can be applied to information resources so that stakeholders can discern their suitability for decision-making or journalistic coverage.

- The Northwest Wind Resource and Action Center developed a Distributed Wind Siting Toolkit that provides guidance to local decision makers about developing smart siting and zoning regulations.

- The Island Institute, as part of the Islanded Grid Resource Center, produced a community engagement handbook for offshore wind development.

The overall wind industry experienced record growth in 2015, rivaling the highest deployment levels of previous years. Congress recently approved 5-year extensions of the Production Tax Credit and Investment Tax Credit, which will undoubtedly spur further wind project developments. However, uncertainty lingers around the lack of stable policy for distributed wind technologies, as well as consistent approaches around the implementation of the federal Clean Power Plan, the wider role of energy in addressing climate change impacts, state renewable portfolio standards, net metering, and other state-based incentives. These uncertain policies are among other challenges that the RRCs continue to address. 


\section{Table of Contents}

Acknowledgments iii

List of Abbreviations and Acronyms iv

Executive Summary $\boldsymbol{v}$

1 Introduction__ 1

2 Four Corners Wind Resource Center__ 3

2.1 Renewable Portfolio Standards _ 3

2.2 Workforce Development___ 4

2.3 Manufacturing __ 5

2.4 Key Stakeholder Groups and Deployment Challenges __ 6

2.5 Collaborating Organizations __ 6

2.6 State Updates — 7

2.6.1 Arizona__ 7

2.6.2 Colorado__ 7

2.6.3 New Mexico ___ 8

2.6.4 Nevada__ 9

2.6.5 Utah _ 9

$3 \quad$ Islanded Grid Resource Center ___ 11

3.1 Renewable Portfolio Standards __ 12

3.2 Workforce Development___ 12

3.3 Manufacturing _ 13

3.4 Key Stakeholder Groups and Deployment Challenges __ 13

3.5 Collaborating Organizations __ 15

3.6 State and Territory Updates __ 15

3.6.1 Alaska__ 15

3.6.2 American Samoa __ 16

3.6.3 Hawaii — 17

3.6.4 Guam _ 17

3.6.5 Commonwealth of the Northern Mariana Islands __ 17

3.6.6 Maine and Other Northeast Island Communities ___ 18

3.6.7 U.S. Virgin Islands___ 18

4 Midwest Wind Energy Center____ 19

4.1 Renewable Portfolio Standards _ 20 
4.2 Workforce Development___ 21

4.3 Manufacturing _ 22

4.4 Key Stakeholder Groups and Deployment Challenges __ 24

4.5 Collaborating Organizations _ 25

4.6 State Updates — 26

4.6.1 Illinois__ 26

4.6.2 Indiana_26 26

4.6.3 lowa 26

4.6.4 Michigan — 27

4.6.5 Minnesota _ 27

4.6.6 Missouri _ 28

4.6.7 North Dakota _ 28

4.6.8 Ohio _ 28

4.6.9 South Dakota _ _ 29

4.6.10 Wisconsin — 29

$5 \quad$ Northeast Wind Resource Center___ 30

5.1 Renewable Portfolio Standards __ 31

5.2 Workforce Development__ 32

5.3 Manufacturing _ 33

5.4 Key Stakeholder Groups and Deployment Challenges __ 33

5.5 Collaborating Organizations _ 34

5.6 State Updates — 35

5.6.1 Connecticut _ _ 35

5.6.2 Maine__ 35

5.6.3 Massachusetts__ 35

5.6.4 New Hampshire _ 36

5.6.5 New Jersey___ 36

5.6.6 New York 37

5.6.7 Pennsylvania _ 37

5.6.8 Rhode Island _ 38

5.6.9 Vermont___ 38

6 Northwest Wind Resource and Action Center___ 39

6.1 Renewable Portfolio Standards __ 39

6.2 Workforce Development___ 41

6.3 Manufacturing __ 41

6.4 Key Stakeholder Groups and Deployment Challenges __ 42

6.5 Collaborating Organizations _ 43 
6.6 State Updates — 43

6.6.1 Idaho_ 43

6.6.2 Montana__ 45

6.6.3 Oregon_46 45

6.6.4 Washington _ 47

6.6.5 Wyoming _ 48

7 Southeast Wind Energy Resource Center__ 49

7.1 Renewable Portfolio Standards _ 50

7.2 Workforce Development__ 50

7.3 Manufacturing _ 51

7.4 Key Stakeholder Groups and Deployment Challenges __ 51

7.5 Collaborating Organizations _ 53

7.6 State Updates $\quad 55$

7.6.1 Alabama__ 55

7.6.2 Arkansas__ 55

7.6.3 Florida 255

7.6.4 Georgia__ 56

7.6.5 Kentucky__ 56

7.6.6 Louisiana _ 56

7.6.7 Mississippi _ 56

7.6.8 North Carolina _ 56

7.6.9 South Carolina _ 57

7.6.10 Tennessee _ 58

7.6.11 Virginia__ 58

8 Updates for States Outside of RRC Regions___ 59

8.1 California _ 59

8.2 Delaware _ 61

8.3 Kansas — 61

8.4 Maryland _ 63

$8.5 \quad$ Nebraska _ 64

8.6 Oklahoma__ 66

8.7 Texas__ 67

8.8 West Virginia _ 69

9 References___ 71 


\section{Table of Figures}

Figure ES-1. Installed wind capacity in the United States as of December 2015 .................................... vi

Figure 1. Map of Regional Resource Centers .................................................................................... 1

Figure 2. Map of school wind turbine projects, educational programs, and locations with both wind turbines and educational programs within the Four Corners Wind Resource Center's area ................ 5

Figure 3. Wind resource at 80 meters overlaid with federal lands ..................................................... 10

Figure 4. Map of school wind turbine projects, educational programs, and locations with both wind turbines and educational programs within the Islanded Grid Resource Center's area ...................... 13

Figure 5. Island Institute team members met with Maine island residents to discuss energy development options for islanded communities. Photo courtesy of Islanded Grid Resource Center ....................... 14

Figure 6. MWEC footprint and average wind speeds at 80 meters ................................................... 19

Figure 7. Map of school wind turbine projects, educational programs, and locations with both wind turbines and educational programs within the Midwest Wind Energy Center's area.....

Figure 8. Map of school wind turbine projects, educational programs, and locations with both wind turbines and educational programs within the Northeast Wind Resource Center's area

Figure 9. Map of school wind turbine projects, educational programs, and locations with both wind turbines and educational programs within the Northwest Wind Resource and Action Center's area 41

Figure 10. Map of school wind turbine projects, educational programs, and locations with both wind turbines and educational programs within the Southeast Wind Energy Resource Center's area.......50

Figure 11. Map of school wind turbine projects, educational programs, and locations with both wind turbines and educational programs in California.

Figure 12. Map of sole educational program location in Delaware ....................................................... 61

Figure 13. Map of school wind turbine projects, educational programs, and locations with both wind turbines and educational programs in Kansas

Figure 14. Map of school wind turbine projects, educational programs, and locations with both wind turbines and educational programs in Maryland....

Figure 15. Map of school wind turbine projects, educational programs, and locations with both wind turbines and educational programs in Nebraska....

Figure 16. Map of school wind educational programs in Oklahoma

Figure 17. Map of school wind turbine projects, educational programs, and locations with both wind

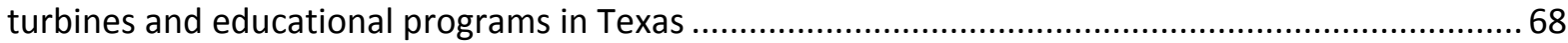

Figure 18. Map of sole school wind educational program in West Virginia ............................................ 70 


\section{Table of Tables}

Table 1. Key Statistics for the Four Corners Wind Resource Center Region............................................ 4

Table 2. RPS Overview for Four Corners Wind Resource Center States ................................................... 4

Table 3. Wind-Related Manufacturing Overview for Four Corners Wind Resource Center States .............. 5

Table 4. Key Statistics for the Islanded Grid Resource Center Region...................................................... 11

Table 5. RPS Overview for Islanded Grid Resource Center States and Territories .................................. 12

Table 6. Key Statistics for the Midwest Wind Energy Center Region .................................................... 20

Table 7. RPS Overview for Midwest Wind Energy Center States........................................................... 21

Table 8. Wind-Related Manufacturing Overview for Midwest Wind Energy Center States ..................... 22

Table 9. Key Statistics for the Northeast Wind Resource Center Region .................................................31

Table 10. RPS Overview for Northeast Wind Resource Center States...................................................... 32

Table 11. Wind-Related Manufacturing Overview for Northeast Wind Resource Center States ...............33

Table 12. Key Statistics for the Northwest Wind Resource and Action Center Region ..............................39

Table 13. RPS Overview for Northwest Wind Resource and Action Center States ................................. 40

Table 14. Wind-Related Manufacturing Overview for Northwest Wind Resource and Action Center

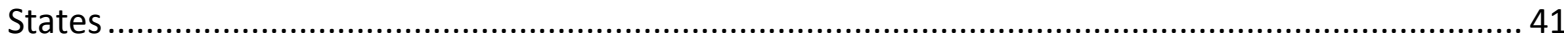

Table 15. Key Statistics for the Southeast Wind Energy Resource Center Region ..................................49

Table 16. RPS Overview for Southeast Wind Resource Center States...................................................5 50

Table 17. Wind-Related Manufacturing Overview for Southeast Wind Energy Resource Center States ..51

Table 18. California Wind-Related Manufacturing Overview ..................................................................6 60

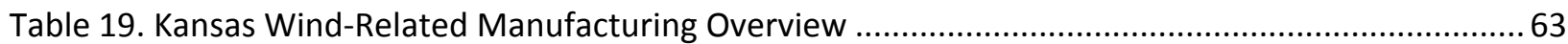

Table 20. Maryland Wind-Related Manufacturing Overview ....................................................................64

Table 21. Oklahoma Wind-Related Manufacturing Overview.............................................................67

Table 22. Texas Wind-Related Manufacturing Overview .......................................................................69 


\section{Introduction}

Significant expansion of wind energy deployment will be required to achieve the Obama Administration's goal of doubling renewable energy production in the United States by 2020. Additionally, the 5-year extension of the federal Production Tax Credit (PTC) and potential early impacts of the state-based responses to the Clean Power Plan also point to robust wind development through the rest of the decade. Wind energy currently provides more than $4 \%$ of the nation's electricity but has the potential to provide much more (U.S. DOE 2015d). Increasing the country's electricity percentage from wind power means cleaner energy, leading to cleaner air and water for the nation, lower energy costs over the long term, and reduced water usage in the power sector.

The wind industry and the U.S. Department of Energy (DOE) Wind and Water Power Technologies Office are addressing technical challenges to increasing wind energy's contribution to the national grid (such as reducing turbine costs and increasing energy production and reliability), and they recognize that public acceptance issues (i.e., wind farm opposition) are barriers to wind energy deployment. Wind energy is a rapidly evolving technology that can play an important role in the U.S. energy generation mix, and credible information about it and the diversity of its possible applications should be communicated to a variety of stakeholders. In 2014, DOE established six Regional Resource Centers (RRCs) to fill this role, providing information to familiarize the public with wind energy, raising awareness about potential benefits and issues, and disseminating data on siting considerations such as turbine sound and wildlife habitat protection.

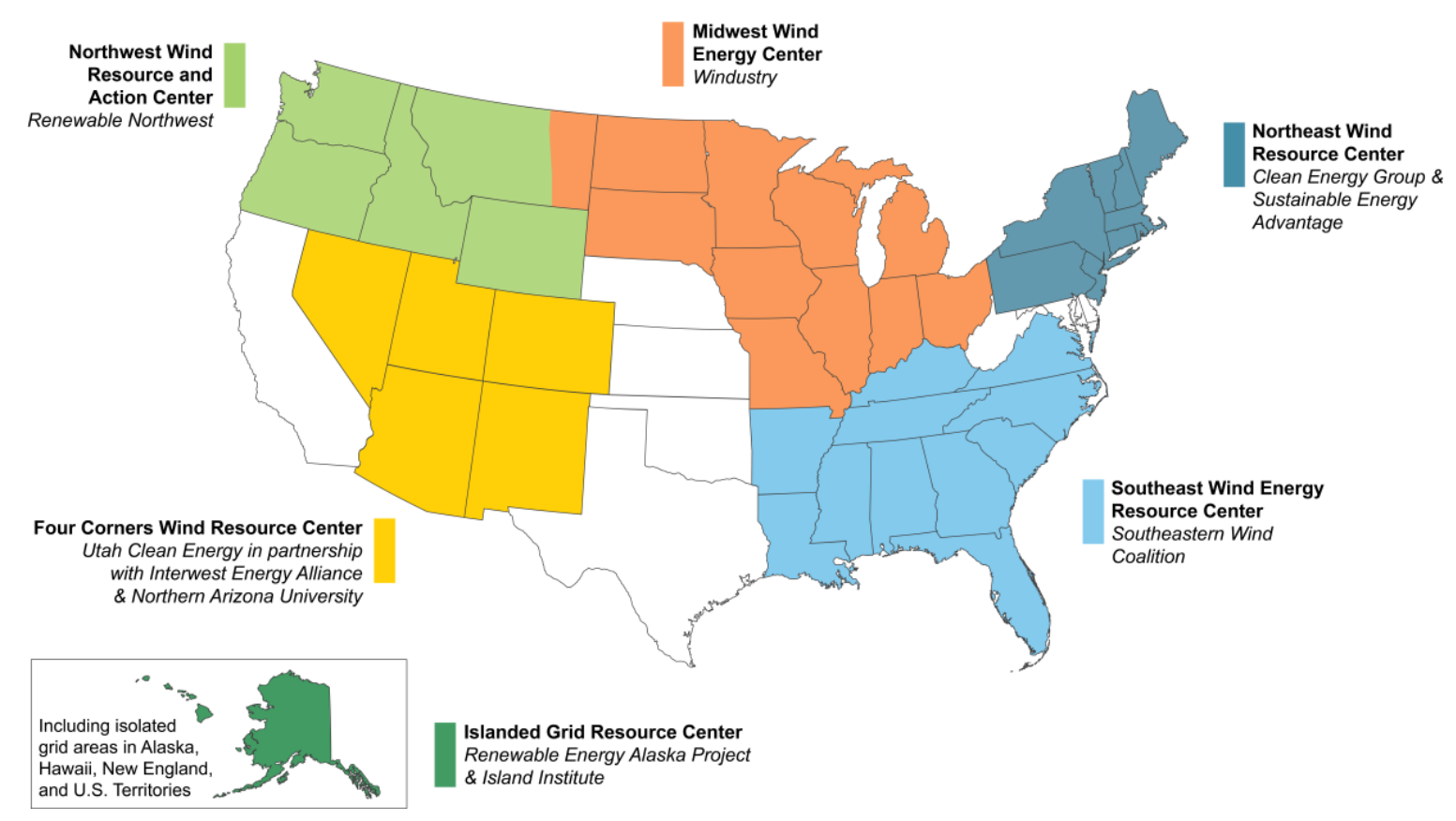

Figure 1. Map of Regional Resource Centers 
The goal of the DOE RRC project is to make it easier for stakeholders and decision-makers to decide whether responsible and appropriate wind project development is right for their communities by:

- Producing relevant, actionable, and fact-based information

- Delivering that information in useful forms to those who need it when they need it.

The RRCs are as follows (in alphabetical order here and in the report sections):

- Four Corners Wind Resource Center, serving Arizona, Colorado, New Mexico, Utah, Nevada, and part of Wyoming

- Islanded Grid Resource Center, serving Alaska, Maine, Massachusetts, Rhode Island, Hawaii, Guam, American Samoa, Commonwealth of Northern Marianas, and U.S. Virgin Islands

- Midwest Wind Energy Center, serving eastern Montana and Illinois, Indiana, Iowa, Michigan, Minnesota, Missouri, North Dakota, Ohio, South Dakota, and Wisconsin

- Northeast Wind Resource Center, serving New England (Connecticut, Maine, Massachusetts, New Hampshire, Rhode Island, and Vermont) and New York for land-based wind, and that same region plus New Jersey for offshore wind

- Northwest Wind Resource and Action Center, serving Washington, Oregon, Idaho, western Montana, and part of Wyoming

- Southeast Wind Energy Resource Center, serving North Carolina, Florida, Louisiana, South Carolina, Georgia, Alabama, Mississippi, Virginia, Kentucky, Tennessee, and Arkansas.

Each RRC applies a unique regional context to identify key stakeholders in the area. Stakeholders may include, for example, county commissioners, state legislators, landowners, tribal authorities, and organizations such as utilities, schools, and non-profit agencies. During their first year of operations, the RRCs reached more than 22,000 key stakeholders and documented that 12,600 of these stakeholders took actions, demonstrating a wider acceptance of wind technology deployment.

This "state of the regions" report provides an overview of each RRC region, describing the regional and state markets for wind development, impact of the current policy environment, and updates on the progress to inject credible information into regional discussions and activities to mitigate the use of biased or misleading information, allowing fair consideration of projects in areas where wind projects could be built.

The role of this document is to summarize the status and drivers for U.S. wind energy development on regional and state levels. This document is intended to be a companion to the Energy Department's 2014 Distributed Wind Market Report (U.S. DOE 2015a), 2014 Wind Technologies Market Report (U.S. DOE 2015b), and 2014 Offshore Wind Market and Economic Analysis (Navigant 2014) that provide assessments of the national wind markets for each of these technologies. 


\section{Four Corners Wind Resource Center}

The Four Corners Wind Resource Center worked with National Renewable Energy Laboratory (NREL) researchers to provide the following assessment of the state of the wind industry in this region.

The Four Corners Wind Resource Center (4CWRC) ${ }^{2}$ is managed by Utah Clean Energy in partnership with Interwest Energy Alliance and Northern Arizona University. The RRC targets wind energy stakeholders in Arizona, Colorado, Nevada, New Mexico, Utah, and Wyoming. Collaborating in this region allows the $4 \mathrm{CWRC}$ to leverage the experience of states with more historic wind deployment experience, like Colorado, Wyoming, and New Mexico, to inform stakeholders and expand markets in Utah, Nevada, and Arizona, including tribal lands. Additionally, the commonalities among the states enable a centralized approach to addressing wind barriers that further leverages resources and efforts within the region. For example, as the region experiences increasing droughts and water shortages, both of which are exacerbated by changes in climate, these arid Southwest states share an interest in water conservation and waterwise energy resources.

Similarly, air quality and haze issues relating to the region's fossil fuel-intensive energy mix is an increasingly critical issue for the states in the region. In light of emerging federal regulations on greenhouse gas emissions from power plants, reducing the carbon intensity of the Western generation mix is increasingly pertinent. As such, the RRC's collaborative efforts focus on promoting the water-saving, air quality, and emissions mitigation benefits of wind energy along with the ripe opportunities this resource provides to meet the West's growing energy needs. Furthermore, coordination and engagement on relevant Western regional transmission, integration, and interconnection issues, including the implementation of an energy imbalance market, ${ }^{3}$ support regional and national efforts to address key barriers to expanding wind power in the Western market.

The following section provides an overview of the wind industry in the 4CWRC region.

\subsection{Renewable Portfolio Standards}

Two of the states in the 4CWRC region have a renewable portfolio standard (RPS) targeting 2020 (Colorado and New Mexico), two have an RPS targeting 2025 (Arizona and Nevada), and Utah has a renewable portfolio goal instead of a standard (Table 1). Wyoming does not currently have an RPS.

Several pieces of legislation to reduce or otherwise roll back the Colorado and New Mexico RPSs were introduced during the 2015 legislative sessions but did not pass. In New Mexico, the state's House of Representatives voted in favor of reducing the $20 \%$ by 2020 renewable energy requirement (Montoya Bryan 2015). The effort stalled as the Senate's Conservation Committee voted to keep the bill from advancing to a full Senate vote (KOB4 2015).

\footnotetext{
${ }^{2}$ http://www.fourcornerswind.org/

3 An energy imbalance market is a means of supplying and dispatching electricity to balance fluctuations in generation and load. It aggregates the variability of generation and load over multiple balancing authority areas.
} 
Colorado's Senate Bill 44 intended to halve the state's $30 \%$ by 2020 renewable requirement for large utilities while reducing the standard for rural electricity associations from $20 \%$ to $15 \%$ starting in 2020. The state's House of Representatives voted down the effort (Bunch 2015). The constitutionality of the state's RPS was also upheld in the Tenth Circuit Court of Appeals, ending litigation that began in 2011 (Proctor 2015).

Table 1. Key Statistics for the Four Corners Wind Resource Center Region

\begin{tabular}{lllllll}
\hline & AZ & CO & NM & NV & UT & WY \\
\hline $\begin{array}{l}\text { Installed Wind, 2015 (MW) } \\
\text { Percentage of Energy }\end{array}$ & 268 & 2,992 & 1,080 & 152 & 327 & 1,410 \\
$\begin{array}{l}\text { Supplied by Wind Projects } \\
(2014)^{5}\end{array}$ & $0.4 \%$ & $13.6 \%$ & $7.0 \%$ & $0.8 \%$ & $1.5 \%$ & $8.9 \%$ \\
$\begin{array}{l}\text { Projected Potential Capacity } \\
\text { (MW), 80 m, 30\% CF }\end{array}$ & 10,904 & 387,220 & 492,083 & 7,247 & 13,103 & 552,072 \\
\hline $\begin{array}{l}\text { Projected Potential Capacity } \\
\text { (MW), 100 m, 30\% CF }\end{array}$ & 25,791 & 429,456 & 568,112 & 12,034 & 26,237 & 593,769 \\
\hline $\begin{array}{l}\text { Contribution from Distributed } \\
\text { Wind Projects, 2014 (MW) }\end{array}$ & 3.33 & 28.8 & 36.6 & 12.3 & 1 & 5.9 \\
\hline
\end{tabular}

Table 2. RPS Overview for Four Corners Wind Resource Center States

\begin{tabular}{ll}
\hline & RPS \\
\hline Arizona & $15 \%$ by 2025 \\
& $30 \%$ by 2020 (investor-owned utilities) \\
& $20 \%$ by 2020 (co-ops serving 100,000 or more meters) \\
Colorado & $10 \%$ by 2020 (co-ops serving fewer than 100,000 meters and \\
Nevada & municipal utilities serving 40,000 or more customers) \\
New Mexico & $25 \%$ by 2025 \\
Utah & $10 \% \times 2020$ (investor-owned utilities) \\
Wyoming & Goal of $20 \%$ by 2025
\end{tabular}

\subsection{Workforce Development}

The 4CWRC region has a strong and well developed wind energy educational infrastructure with colleges or universities active in all six states in the region; see each state section for specifics. The WINDExchange website also offers information and interactive maps regarding workforce development, the DOE's Collegiate Wind Competition, the DOE's Wind for Schools project,

\footnotetext{
${ }^{4} 2015$ Year End Wind Power Capacity Map. Available at http://apps2.eere.energy.gov/wind/windexchange/wind installed capacity.asp

${ }^{5}$ U.S. Energy Information Administration Electricity Data Browser. Available at http://www.eia.gov/electricity/data/browser/\#/topic/0?agg $=1,0,2 \&$ fuel=008\&geo $=0000000001$ jo \&sec $=03 g \&$ freq $=$ A\&start=2001\&end=2014\&ctype=linechart\&ltype=pin\&rtype=s\&maptype=0\&rse=0\&pin=

${ }^{6}$ Distributed wind project installed capacity is defined as 2003-2014 cumulative capacity (DOE 2015a).
} 
school wind project locations, and locations of education and training programs in the 4CWRC region and other states. ${ }^{7}$

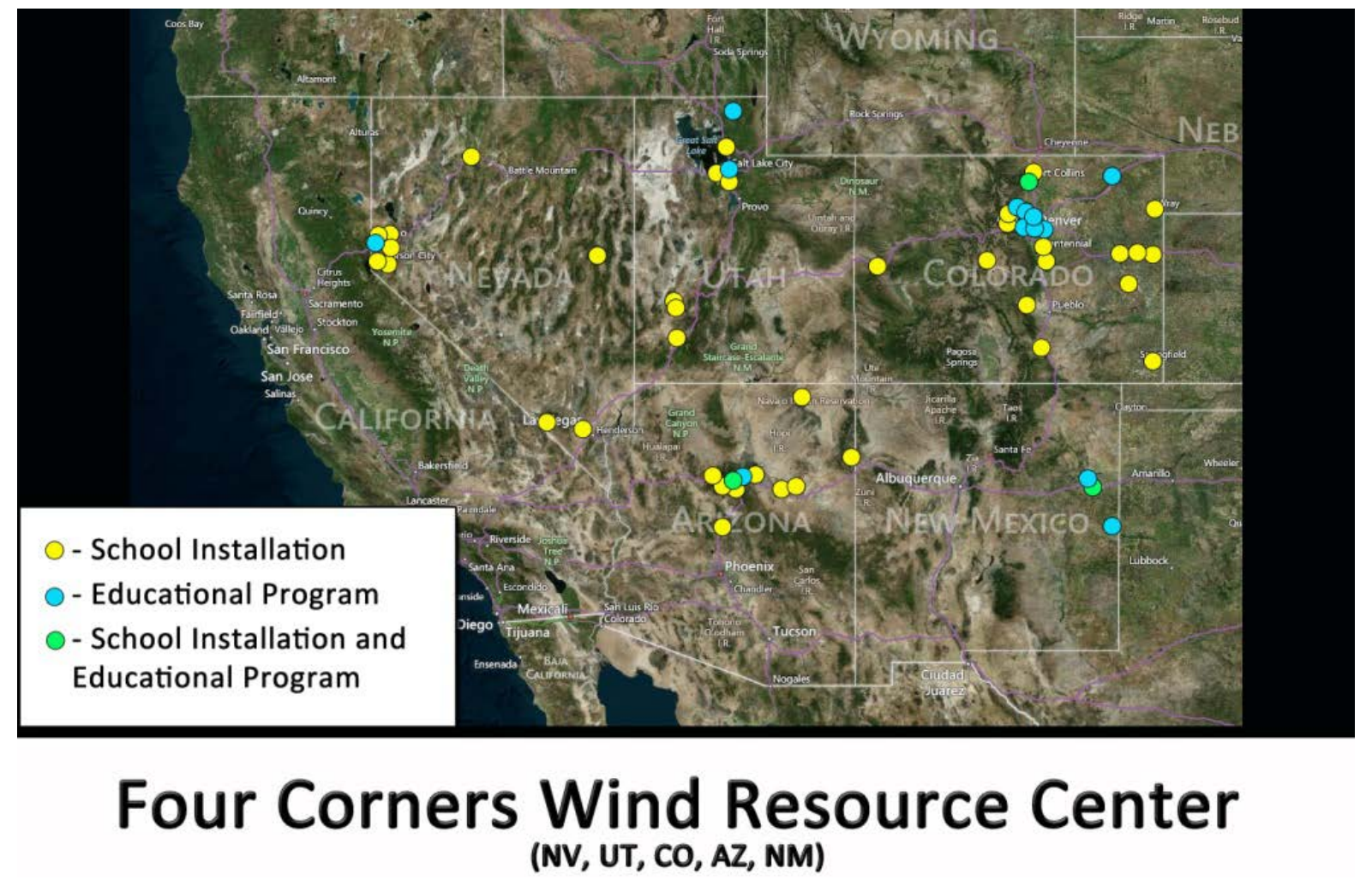

Figure 2. Map of school wind turbine projects, educational programs, and locations with both wind turbines and educational programs within the Four Corners Wind Resource Center's area

\subsection{Manufacturing}

NREL researchers compiled the following wind energy manufacturing data for this region as part of DOE's annual wind market report effort (DOE 2015c). Nevada, New Mexico, Utah, and Wyoming do not have any manufacturing facilities supporting the wind industry. In Table 3, Tier I represents major components such as blades and towers, and Tier II components are subcomponents, such as inverters and electrical equipment, to make the Tier I equipment.

Table 3. Wind-Related Manufacturing Overview for Four Corners Wind Resource Center States

\begin{tabular}{lllll}
\hline Name & City & State & Component & Tier \\
\hline Power-One & Phoenix & AZ & Power converters & II \\
Cobham Slip Rings & Prescott & AZ & Slip rings & II \\
Primus Windpower & Lakewood & CO & Distributed wind & I \\
Vestas & Windsor & CO & Blades & I \\
Vestas & Brighton & CO & Blades & II \\
Woodward Governor & Fort Collins & CO & Inverters & II \\
SGB USA & Wheat & CO & Electrical & \\
& Ridge & & & \\
\hline
\end{tabular}

${ }^{7}$ http://apps2.eere.energy.gov/wind/windexchange/schools/ 


\begin{tabular}{lllll}
\hline Name & City & State & Component & Tier \\
\hline PMC Technology & Golden & CO & Hydraulics & II \\
O’Neal Steel & Pueblo & CO & Tower internals & II \\
Aluwind & Castle & CO & Tower internals & II \\
& Rock & & & \\
Vestas & Pueblo & CO & Towers & I \\
Vestas & Brighton & CO & Turbine (nacelle assembly) & I \\
\hline
\end{tabular}

\subsection{Key Stakeholder Groups and Deployment Challenges}

The 4CWRC targets three stakeholder groups:

- Utility regulators, commissioners, utility representatives, and staff

- State, local, and tribal decision makers and staff

- Interested members of the public.

The information provided to these stakeholder groups addresses the following wind energy deployment market barriers that are prevalent in this region:

- Insufficient transmission capacity that has historically hindered growth in the region

- Lack of local wind siting ordinances or ordinances that do not reflect best practices

- Wind technology costs and outputs

- Integration challenges and costs

- Lack of clear policy direction supporting wind

- Misinformation and negative public opinion regarding wind energy

- Wildlife issues

- Challenges with development on federal land.

\subsection{Collaborating Organizations}

Organizations that have collaborated with the 4CWRC include:

- Advanced Energy Economy

- American Wind Energy Association

- Arizona Governor's Office of Energy Policy

- Beaver County, Utah

- Coconino County, Arizona

- Colorado Energy Office
- Colorado State University Center for the New Energy Economy

- Distributed Wind Energy Association

- Hopi Tribe Renewable Energy Office

- Hualapai Tribe Planning Office

- Lincoln County, Colorado

- New Mexico Renewable Energy Transmission Authority 
- State of New Mexico Energy, Minerals and Natural Resources Department

- State of Utah Office of Energy Development
- Summit County Council

- Western Area Power Administration.

\subsection{State Updates}

Although the 4CWRC contributes to engagement activities in Wyoming, in this report the state's activities are listed in the Northwest Wind Resource and Action Center's section.

\subsubsection{Arizona}

By the end of 2015, Arizona had 268 megawatts (MW) of installed wind capacity

(WINDExchange 2016). The wind industry in Arizona supplied \$710,000 in annual land lease payments to farmers, ranchers, and other landowners (AWEA 2015a).

Wind energy development in Arizona slowed down with the fulfillment of state utility RPS goals; the instability of the federal Production Tax Credit; BP's exit from renewable energy development; and the preference of the Hualapai Tribe, Navajo Nation, and Hopi Tribe for solar development over wind. Development ceased on a number of projects that were well underway with feasibility or pre-construction studies. These include BP's wind project (up to $500 \mathrm{MW}$ ), Gray Mountain (500 MW) and Big Boquillas (180 MW) on the Navajo Nation, and Hualapai $(170 \mathrm{MW})$ and Hopi (100 MW) proposed projects. In addition, developers of the Sunshine Wind Project permitted for $40 \mathrm{MW}$ for Foresight Renewables elected not to renew the county permit. Resource assessment is taking place in a number of counties, but there is no indication that projects will be built in the near term.

The 4CWRC is working with the Hopi Tribe on resource assessment activities and tribal council education on wind development steps and is supporting the Hualapai Tribe in pursuing additional wind resource assessment.

Arizona is also participating in the DOE Wind for Schools project; Northern Arizona University has led the effort and the installation of 18 school systems in the state. Northern Arizona University also participated in the 2014 Collegiate Wind Competition and is an entrant for the 2016 Competition.

\subsubsection{Colorado}

The wind industry is a thriving market in Colorado, with wind power providing nearly $14 \%$ of the electricity generated in the state by the end of 2014. By the end of 2015, Colorado had 2,992 MW of installed wind capacity (WINDExchange 2016). The wind industry in Colorado provided a total capital investment of $\$ 4.8$ billion across 24 projects and more than $\$ 7.8$ million in annual land lease payments to farmers, ranchers, and other landowners (AWEA 2015c). Communities benefit from a broader tax base, which helps to pay for roads, schools, and other critical public projects.

Colorado's RPS has helped to spur wind development in the state. The original RPS was established when Colorado voters approved Amendment 37 in 2004, and the legislature has 
made several adjustments over the years. Investor-owned utilities must meet a $30 \%$ by 2020 renewable standard. Legislation passed during the 2013 session increased the standard for electric co-ops serving 100,000 or more electric meters to $20 \%$ by 2020 and left the standard at $10 \%$ by 2020 for smaller co-ops and municipal utilities.

Recent low prices for wind power have spurred procurement over and above state RPS requirements. The Colorado Public Utilities Commission approved a 2011 Public Service Company of Colorado's request to add $450 \mathrm{MW}$ of new wind resources acquired at unprecedented low bid prices, finding that the wind energy would save ratepayers $\$ 231$ million from the displacement of fuel and variable operating costs required by facilities powered by fossil fuels (Xcel Energy 2015). Diversifying Colorado's energy supply with wind provides long-term price stability, protecting consumers when natural gas prices suddenly increase.

Like many states, barriers to increased wind development in Colorado include instability of the federal Production Tax Credit and transmission constraints. Public Service Company of Colorado is exploring the possibility of joining a regional transmission energy imbalance market, which could provide additional opportunities for Colorado wind. Continued low costs of wind, compliance with the Environmental Protection Agency's Clean Power Plan, and Public Service Company of Colorado's ongoing improvements in integration and forecasting technology present opportunities for more Colorado wind power.

Colorado has been heavily engaged in wind energy education, with university programs at Colorado State University, University of Colorado at Boulder, and the Colorado School of Mines. These three educational organizations have teamed with NREL to develop the Center for Research and Education in Wind, ${ }^{8}$ a research center under the Colorado Renewable Energy Collaboratory. The Colorado School of Mines also participated in the 2014 Collegiate Wind Competition. Colorado also participates in the DOE's Wind for Schools project; Colorado State University leads the effort with 12 school systems currently installed in the state. The Ecotech Institute in Aurora, Colorado, hosts an extensive wind technician training program.

\subsubsection{New Mexico}

At the end of 2015, New Mexico was home to 1,080 MW of installed wind capacity (WINDExchange 2016) with 330 MW under construction (AWEA 2015h). State utilities are on track to meet a $20 \%$ by 2020 RPS for investor-owned utilities and $10 \%$ by 2020 for rural electric co-ops. In addition to the RPS, the state's renewable energy production tax credit (available for wind, solar, and biomass) has contributed to wind project development in the state. The New Mexico Energy, Minerals \& Natural Resources Department recently commissioned an economic analysis of the state renewable energy production tax credit, which was published in February 2015. The study indicated that between 2003 and 2012, the state expended \$61.6 million on the production tax credit (of which $\$ 54.2$ million was for wind projects). For these same projects and time period, the study estimates the total labor income impacts to New Mexico's economy were $\$ 434$ million and more than 9,000 jobs, with more than $80 \%$ of the impact coming from wind facilities. The study estimates an additional value of more than $\$ 400$ million of avoided emissions in the state (New Mexico Energy, Minerals and Natural Resources Department 2015).

\footnotetext{
${ }^{8}$ http://crew.colorado.edu/
} 
New Mexico's relatively slow economic recovery from the global recession combined with a small, rural population presents challenges for finding in-state markets for new wind development. In addition, utilities serving New Mexico customers have frequently chosen solar PV in relatively small megawatt procurements for RPS compliance. New Mexico's state utilities and the Public Regulation Commission have not demonstrated a willingness to consider beyondRPS renewable energy purchases.

The most significant opportunities for New Mexico wind are likely in western markets beyond its borders. While there are transmission constraints for exports, several major projects are underway, including SunZia, Southline, and Western Spirit.

The Southwest Technology Development Institute based at New Mexico State University has a long history of outreach and development work focusing on distributed wind technologies.

\subsubsection{Nevada}

Nevada's first (and only) utility-scale wind project, Spring Valley, came online in 2012 near Ely. Spring Valley is a 152-MW project with total capital investment of approximately $\$ 280$ million (AWEA 2015g). While wind developers remain interested in Nevada, wind energy developers face competition from the state's strong solar and geothermal resources. However, NV Energy's recent announcement that it plans to join the regional energy imbalance market could help to create additional opportunities for Nevada wind power throughout the region.

The state still faces many hurdles regarding the wildlife impacts or perceived potential impacts associated with wind energy. Concerns include golden eagles (Brean 2015), Mexican free-tailed bats, and desert tortoises. These hurdles have resulted in project delays and increased measures to reduce impacts from Spring Valley. An additional challenge related to the expansion of wind energy in Nevada pertains to siting issues on or near federal lands (Emmerich 2015) (which comprise $81.1 \%$ of Nevada's total acreage) (Congressional Research Service 2014). Figure 3 shows the U.S. wind resource at 80 meters overlaid with federal land.

\subsubsection{Utah}

Utah has four wind projects online with a total of $327 \mathrm{MW}$ of installed capacity and $144 \mathrm{MW}$ under construction. The industry supplies nearly $\$ 1$ million in annual land lease payments to farmers, ranchers, and other landowners (AWEA 2015o). Two of the four wind projects are located in Beaver County, where these projects increased the tax base from $\$ 680$ to more than $\$ 3$ million, paying for a new hospital, a new elementary school, and improved road infrastructure.

Challenges to wind development in Utah include the state's use of a voluntary renewable energy goal of $20 \%$ by 2025 instead of a mandatory standard, a lack of available transmission capacity, issues siting on or near federal lands that comprise $66.5 \%$ of Utah's total acreage (Congressional Research Service 2014), lack of wind siting ordinances, developer efforts focused on solar prior to the scheduled reduction of the federal investment tax credit for solar, and integration challenges including costs. The 4CWRC is working to address many of these challenges.

PacifiCorp's recent announcements that it plans to join the regional energy imbalance market and explore the possibility of joining the California ISO could help to create additional opportunities for Utah wind power throughout the region. 


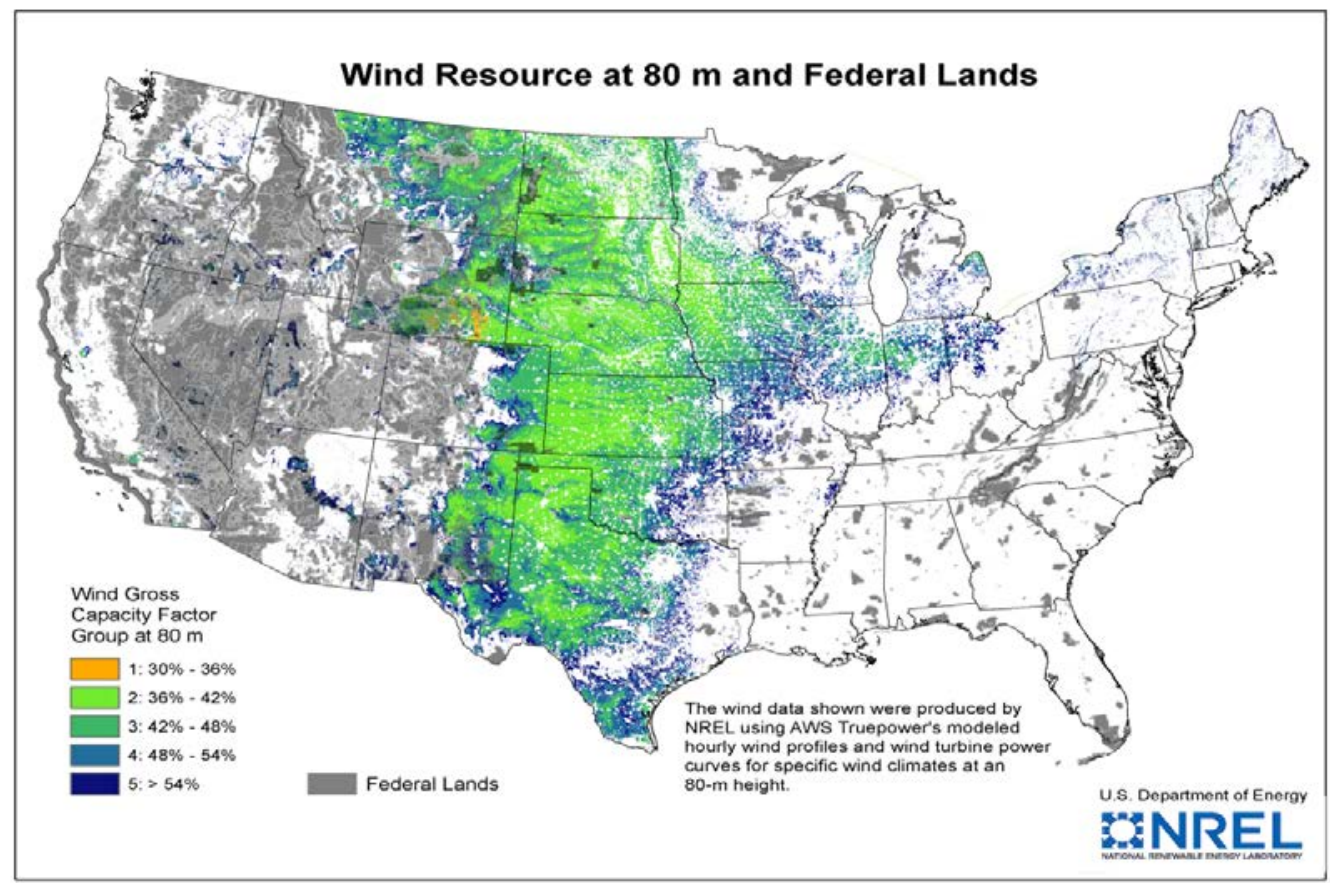

Figure 3. Wind resource at $\mathbf{8 0}$ meters overlaid with federal lands 


\section{Islanded Grid Resource Center}

The Islanded Grid Resource Center worked with NREL researchers to provide the following assessment of the state of the wind industry in this region.

Interested parties of the Islanded Grid Resource Center ${ }^{9}$ are located in Alaska, Maine, Massachusetts, Rhode Island, ${ }^{10}$ Hawaii, Guam, American Samoa, Commonwealth of the Northern Mariana Islands (CNMI), and U.S. Virgin Islands. The three main focus areas of the $\mathrm{RRC}$ are wind-diesel systems, megawatt-scale systems on islanded grids, and support for island communities in close proximity to proposed commercial-scale offshore wind and other ocean energy projects. Any interested party may join the group.

Although not linked geographically, islanded grid communities share common challenges and opportunities for wind development. Most have small populations with limited human capacity and sub-optimal infrastructure. Transportation and distribution costs tend to be higher than in other parts of the country, exacerbating financing challenges. Many of these communities have severe climates and/or are being impacted by climate change and rising sea levels. Most rely on expensive diesel fuel (subject to volatile price swings) to generate electricity and therefore share technical difficulties associated with wind integration. Reliance on diesel fuel comes with a host of environmental concerns, including meeting emissions standards, the need for bulk fuel storage, and the potential for diesel spills. However, many of the islanded grid communities have excellent wind resources, with some in close proximity to proposed offshore wind projects.

Because islanded communities are remote and geographically distant, many of these jurisdictions have not traditionally communicated with each other about progress related to wind energy implementation. Currently, islands and islanded regions have few places to turn for help. These regions rarely can look to wind development on large-scale grid systems as models, and, with sparse funding and resources, they have limited ability to do testing and development work on their own.

The following section provides an overview of the wind industry in the Islanded Grid Resource Center region.

Table 4. Key Statistics for the Islanded Grid Resource Center Region

\begin{tabular}{|c|c|c|c|c|}
\hline & Alaska & Guam & Hawaii & $\begin{array}{l}\mathrm{NE} \\
\text { Islands }\end{array}$ \\
\hline Installed Wind, 2015 (MW) & 66 & .005 & 203 & 4.5 \\
\hline $\begin{array}{l}\text { Percentage of Energy } \\
\text { Supplied by Wind Projects }\end{array}$ & $2 \%$ & $<1 \%$ & $5 \%$ & \\
\hline $\begin{array}{l}\text { Projected Potential } \\
\text { Capacity (MW), } 80 \text { m, } \\
30 \% \text { CF }\end{array}$ & 2,902 & & 3,265 & \\
\hline
\end{tabular}

\footnotetext{
${ }^{9}$ http://islandedgrid.org/

${ }^{10}$ Maine, Massachusetts, and Rhode Island are also part of the Northeast Wind Resource Center region.
} 


\begin{tabular}{lcccc}
\hline & Alaska & Guam & Hawaii & $\begin{array}{l}\text { NE } \\
\text { Islands }\end{array}$ \\
\hline $\begin{array}{l}\text { Projected Potential } \\
\text { Capacity (MW), } 100 \mathrm{~m},\end{array}$ & $3,765^{11}$ & & \\
$\begin{array}{l}30 \% \mathrm{CF} \\
\begin{array}{l}\text { Contribution from } \\
\text { Distributed Wind Projects, }\end{array}\end{array}$ & & 3,564 & \\
$2014(\mathrm{MW})^{12}$ & 12.9 & & \\
\hline
\end{tabular}

\subsection{Renewable Portfolio Standards}

Alaska does not have an RPS but has a renewable energy goal to be $50 \%$ powered by renewables by 2025. Hawaii enacted an RPS in 2001 and includes wind as an eligible technology in its standard. Applicable sectors are investor-owned utilities and rural electric cooperatives. Each of the U.S. Territories covered by this RRC has an RPS with the exception of American Samoa, which does not yet have one, and the U.S. Virgin Islands, which has renewable targets.

Table 5. RPS Overview for Islanded Grid Resource Center States and Territories

\begin{tabular}{ll}
\hline & RPS \\
\hline Alaska & Target: $50 \%$ of electrical generation by 2050 \\
American Samoa & None \\
Guam & $5 \%$ of net electricity sales from renewables by 2015 and $25 \%$ \\
Hawaii & of sales by 2035 \\
CNMI & $30 \%$ of net electricity sales by $2020 / 100 \%$ of sales by 2045 \\
Maine & $20 \%$ of net electricity sales by 2016. \\
& $40 \%$ of net electricity sales by 2017 \\
U.S. Virgin Islands & Targets: $20 \%$ by $2015 ; 25 \%$ by $2020 ; 30 \%$ by $2025 ;$ increasing \\
& until $51 \%$ of generating capacity is derived from renewable or \\
& alternative energy
\end{tabular}

\subsection{Workforce Development}

The Power Systems Integration Lab (formerly the Alaska Wind-Diesel Wind Application Center) is located at the University of Alaska-Fairbanks and supports educational programs through the Alaska Center for Energy and Power. The University of Alaska Fairbanks has also participated in the Collegiate Wind Competition and, in collaboration with the Renewable Energy Alaska Project, supported a state Wind for Schools effort. The Alaska Institute for Technology has also supported technical curricula associated with the operation and maintained of wind energy as part of its remote power system technician training curricula, supporting wind deployment in remote and islanded communities. See the map below for the locations of other school projects. The WINDExchange website also offers information and interactive maps regarding workforce development, the DOE's Collegiate Wind Competition, the DOE's Wind

\footnotetext{
${ }^{11}$ Estimates provided by Alaska Energy Authority Wind Program Manager Rich Stromberg, based on developable land likely being limited to private land

12 Distributed wind project installed capacity is defined as 2003-2014 cumulative capacity (DOE 2015a).
} 
for Schools project, school wind project locations, and locations of education and training programs in the Islanded Grid region and other states. ${ }^{13}$

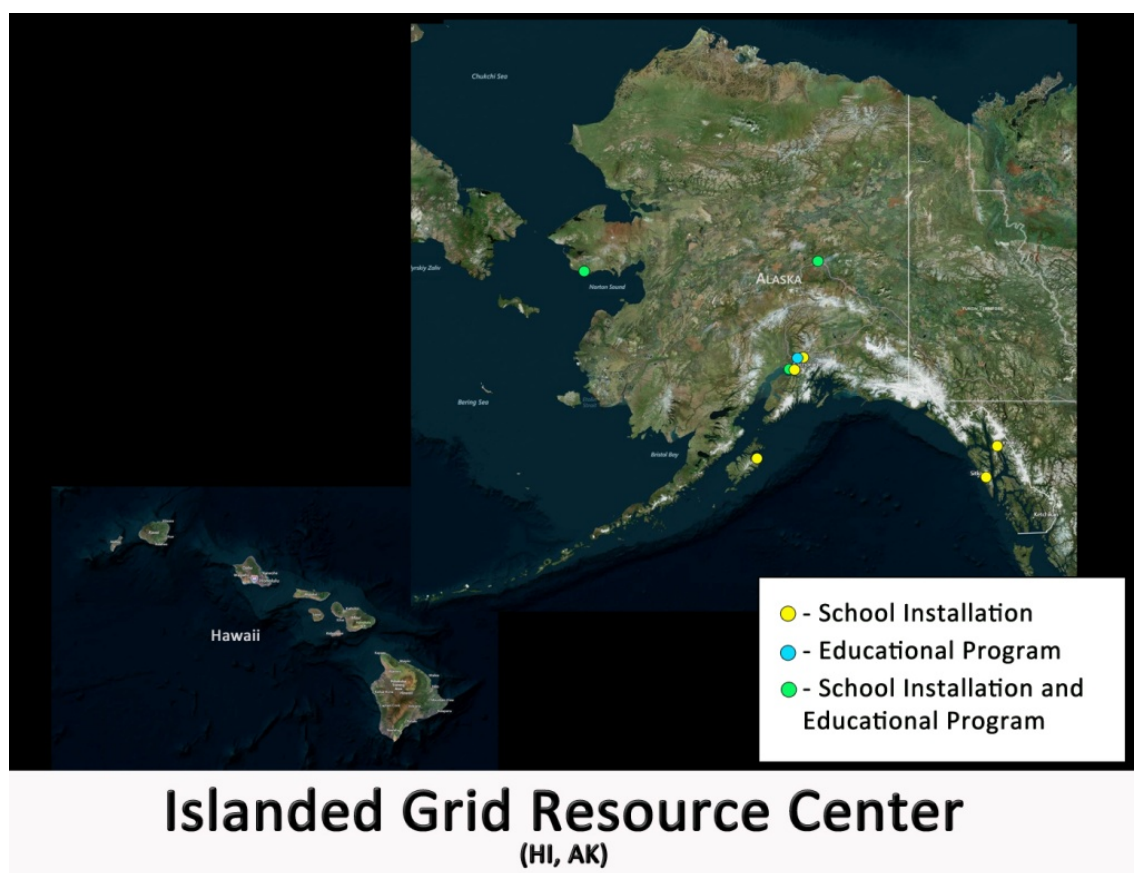

Figure 4. Map of school wind turbine projects, educational programs, and locations with both wind turbines and educational programs within the Islanded Grid Resource Center's area

\subsection{Manufacturing}

There is no wind-related manufacturing in the region.

\subsection{Key Stakeholder Groups and Deployment Challenges}

The Islanded Grid Resource Center targets these stakeholder groups:

- Utilities and wind operators

- Researchers and technical experts

- Trade associations and non-profits

- Military

- Policymakers, elected and non-elected

- Manufacturers and supply chain businesses

- General public.

The information provided to these stakeholder groups addresses the following wind energy deployment market barriers that are prevalent in this region:

${ }^{13}$ http://apps2.eere.energy.gov/wind/windexchange/schools/ 
- The primary development challenge facing wind-diesel development is the upfront cost of deploying a sophisticated system in a remote area with relatively low technical and human capacity. Since most of these grids are off the road system, transportation and mobilization costs are much higher than they are for communities in other regions on the road system. Besides transportation and mobilization, another challenging cost driver is scale.

- There are several wind energy development challenges for large islanded grids in the Railbelt transmission system ${ }^{14}$ in Alaska. They include the region's heavy dependence on natural gasfired power; the risk-adverse nature of the six utilities serving the region, which prevents them from accepting wind energy; a relatively weak, inflexible grid that makes it more difficult to integrate wind power; lack of clear regulatory policy that defines the rules of engagement between those utilities and independent power producers that wish to develop wind; lack of a universal transmission tariff; lack of any regional generation and transmission planning; and lack of any regional transmission organization or independent system operator.

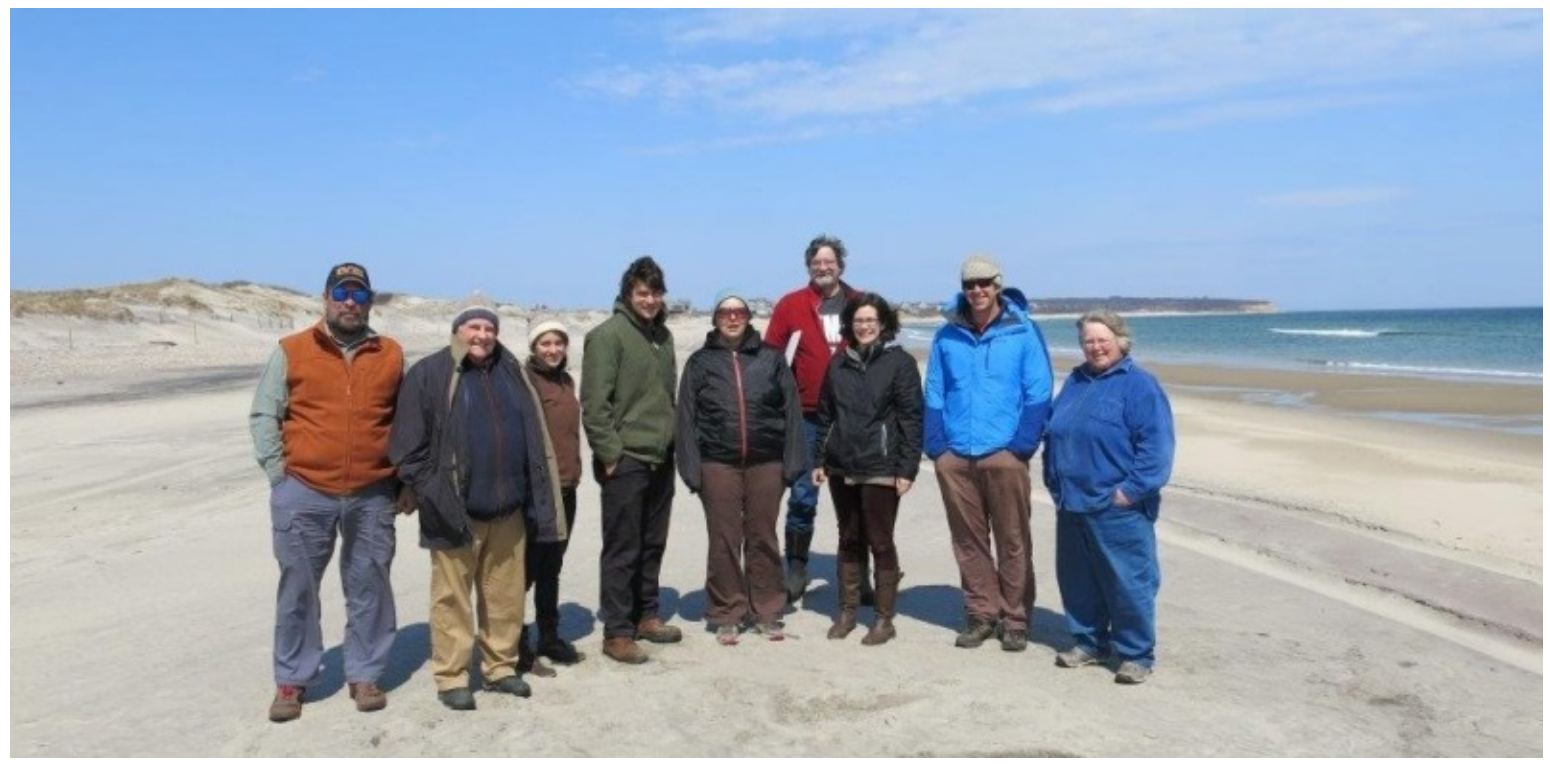

Figure 5. Island Institute team members met with Maine island residents to discuss energy development options for islanded communities. Photo courtesy of Islanded Grid Resource Center

\footnotetext{
${ }^{14}$ A small, isolated transmission system in Alaska that covers the main population centers of the state along the main railroad line including the Seward, the Kenai, Anchorage, Wasilla, and north to Fairbanks
} 


\subsection{Collaborating Organizations}

Organizations that have collaborated with the Islanded Grid Resource Center include:

- Alaska Center for Energy and Power

- Alaska Congressional Delegation

- Alaska Energy Authority

- Alaska Federation of Natives

- Alaska Power and Telephone Company

- Alaska Village Electric Cooperative

- American Samoa Power Authority

- American Wind Energy Association

- Bergey Windpower Company

- Chugach Electric Association

- College of the Atlantic

- Commonwealth Utilities Corporation (CNMI)

- Cook Inlet Region Inc.

- Cuttyhunk Electric

- Distributed Wind Energy Association

- Endurance Wind Power

- Fox Islands Electric Cooperative

- Guam Power Authority

- Hawaii Natural Energy Institute

- Kodiak Electric Association
- Maine Congressional Delegation

- Maine PUC

- Marsh Creek LLC

- Martinicus Isle Plantation

- Monhegan Plantation Power District

- Naushon Trust

- Ocean Renewable Power Company

- Sgurr Energy

- Solar Electric Light Fund

- Star Island Corporation

- State of Alaska

- Swan's Island Electric Cooperative

- Town of Nantucket

- Town of New Shoreham

- University of Alaska Anchorage Institute of Social \& Economic Research

- University of Maine

- U.S. Virgin Islands Energy Office

- U.S. Department of Agriculture Rural Development

- Utility Variable-Generation Integration Group.

\subsection{State and Territory Updates}

\subsubsection{Alaska}

Alaska has two distinct markets for wind development: larger communities that are connected by the Railbelt and rural communities that are completely isolated from the state's grid. At the end of 2015, Alaska had $62 \mathrm{MW}$ of installed wind capacity, including $41 \mathrm{MW}$ of capacity added since 2012 on the Railbelt grid that serves Anchorage, the main population center. One notable 
success is the 9-MW system located on Kodiak Island. ${ }^{15}$ Coupled with hydro and a battery and flywheel system, this system made the island $99.7 \%$ powered by renewables.

Barriers to wind development in Alaska continue to be cost and the fact that high-contribution wind systems are technically complicated. The Islanded Grid Resource Center shares information on technical barriers, including control systems, secondary load control, and the use of energy storage. Other barriers include limited technical training, support, and human capacitybuilding for remote communities; limited financing; misalignment of the state's power cost equalization fuel subsidy and incentives to decrease diesel usage; complicated foundation technology (due to areas of permafrost); high mobilization, construction, and logistics costs; and lack of understanding of the long-term benefits and applicability of wind technology to reduce usage of imported fuel options.

In the past year, the state experienced a severe fiscal shock as the price of oil dropped precipitously and drastically reduced the state's revenues. As a result, the Alaska Renewable Energy Fund, the state's primary renewable energy driver, has experienced and could continue to experience major funding cuts by the state legislature into the near future. Several entities are working to make private, alternative financing available and to increase the percentage of state funds that are available for resource assessments and feasibility studies. Energy stakeholders are also working to reform the power cost equalization program to provide incentives for communities to use less diesel through renewables and efficiency. In the Railbelt, there has been significant progress toward establishing an independent system operator that would set a universal transmission tariff and help level the playing field for new wind developments. Progress has also been made in creating a private transmission company to finance needed transmission upgrades to further facilitate economic dispatch of the grid by the independent system operator.

Alaska participates in the Wind for Schools project. The University of Alaska Fairbanks worked to help install seven school systems in the state, participated in the 2014 Collegiate Wind Competition, and is an entrant for the 2016 Competition.

\subsubsection{American Samoa}

American Samoa, an unincorporated territory of the United States, is a group of five islands about halfway between Hawaii and New Zealand in the South Pacific Ocean. The territory's only utility, the American Samoa Power Authority, provides electric, water, wastewater, and solid waste utility services for its 12,300 customers. American Samoa is almost completely dependent on fossil fuels for meeting its energy generation needs. In 2014, the peak load averaged about 22 MW with annual diesel generation totaling 154 million kilowatt-hours. To date, American Samoa Power Authority has installed $2 \mathrm{MW}$ of photovoltaic solar panels near the Pago Pago International Airport, which generates about $2 \%$ of the utility's power. American Samoa currently has no wind projects installed. In 2013, the governor established the American Samoa Renewable Energy Committee, which developed a strategic energy plan and energy action plan. The plan includes a goal for Manu'a Islands, American Samoa's easternmost group, to be 100\% powered by renewables by 2016 .

\footnotetext{
${ }^{15}$ Learn more at http://islandedgrid.org/100-renewably-powered-alaskas-kodiak-island-goes-all-in-with-wind-andhydro/
} 


\subsubsection{Hawaii}

Hawaii's governor signed a law requiring $100 \%$ of Hawaii's electricity to be generated by renewable sources by 2045, increasing the state's former renewable energy goal of $40 \%$ clean energy by 2040 (Hawaii Clean Energy Initiative 2015). Hawaii had 203 MW of installed wind capacity as of the end of 2015 (WINDExchange 2016), providing 5\% of the state's electricity. The state has substantial renewable resources throughout the island chain and has a robust wind regime with wind farms' capacity factors exceeding those commonly found elsewhere. Utilityscale wind potential is found onshore and offshore, with the state's six commercial wind farms on Oahu, Maui, and the "big island" of Hawaii. There are two proposals for offshore wind development off Hawaii's coasts. The 408-MW Alpha Wind Energy floating offshore wind farm, which would transmit electricity to Oahu through an undersea cable, has submitted a license proposal with the Bureau of Ocean Energy Management (BOEM).

Hurdles to wind development in Hawaii include endangered avian and plant species that can complicate the siting and development of wind projects in Hawaii's unique environments. Visual impacts can also be of concern, given the height of wind turbines and limited sites suitable for wind development in Hawaii.

\subsubsection{Guam}

Guam, the largest island in Micronesia, is located in the Pacific Ocean about three-fourths of the way from Hawaii to the Philippines. Surrounded by coral reef, Guam sits on the edge of the Mariana Trench and its Challenger Deep, the deepest known place on earth. Guam has no renewable resources and meets nearly all of its energy needs, including electricity, with petroleum products shipped in by tanker. The island's population is estimated to be about 161,000 , plus 12,000 to 14,000 military personnel and their dependents.

Guam has substantial wind potential but also unique siting issues. It is seismically active and is in the Pacific's Typhoon Alley, so wind turbines must be engineered to resist earthquakes and typhoon-force winds. Other barriers to wind deployment on Guam include limited land, potential windy sites on privately owned land, concerns over aesthetics of wind turbines, a large amount of military land that may create issues with zoning variances, no local tax incentive, bat concerns, and other potential environmental impacts. Both the Navy and Guam Power Authority have conducted wind resource mapping and assessments, and the Guam Power Authority installed a 275-kW turbine in 2015 as a pilot project (Dumat-ol Daleno 2016). Guam currently has a renewable energy portfolio goal that calls for $5 \%$ of net electricity sales to come from renewable energy resources by 2015 , increasing to $25 \%$ by 2035 .

\subsubsection{Commonwealth of the Northern Mariana Islands}

The CNMI is a chain of 14 islands in the Pacific Ocean, located between Hawaii and the Philippines. Only three islands on the southern end of the island chain are currently inhabited: Saipan, Tinian, and Rota. About 9 in 10 residents live on Saipan, the largest island. The population has been shrinking and totaled about 54,000 in the 2010 U.S. Census. The islands meet nearly all of their energy demand through imported petroleum products, including 22 million to 24 million gallons of diesel fuel annually to run the islands' five electricity-generating plants. The CNMI's electric system is owned and operated by the Commonwealth Utilities Corporation, a public corporation of the CNMI government. The CNMI has three small electric 
grids, one on each of the inhabited islands. Generating capability is about $70 \mathrm{MW}$ on Saipan, 20 MW on Tinian, and 4.5 MW on Rota.

Saipan, Tinian, and Rota are believed to have prevailing wind resources suitable for commercial turbines. However, potential sites are limited because the islands are mountainous, land is scarce, and turbines may interfere with airstrip and military facilities. There are also concerns about turbine impacts on several threatened bird species. Turbines must also be designed to withstand typhoons.

\subsubsection{Maine and Other Northeast Island Communities}

Several New England island communities have investigated community-scale wind as a costeffective option for reducing high, primarily diesel-based energy costs, but none of the islands has installed wind power generation since the 4.5-MW Fox Islands Wind Project was constructed in 2009. The Deepwater Wind project off Block Island, Rhode Island, is also in development but does not represent island projects because of its interconnection to the main grid. The Islanded Grid Resource Center has worked with the Block Island community and other island communities that face the potential development of large-scale offshore wind projects.

\subsubsection{U.S. Virgin Islands}

The U.S. Virgin Islands is a U.S. territory located in the Caribbean, about 600 miles from Miami, Florida. The U.S. Virgin Islands has two separate electricity grids, each with its own generation, managed by the Water and Power Authority, an independent government agency. Generating units include combustion, steam turbines, and backup diesel, all fueled by imported petroleum. The 199-MW St. Thomas system supplies nearby St. John and Water Island by underwater cable. The 122-MW St. Croix system, separated from St. Thomas by 40 miles of ocean, has its own grid. The USVI government's goal of reducing fossil fuel use $60 \%$ by 2025 has led to working with U.S. federal agencies and industry to find other energy sources. More than half of reductions are planned to come from energy efficiency, particularly in generation, transmission, street lighting, and desalination, with the balance coming from wind, solar, and biomass technologies, including waste-to-energy and landfill gas.

The U.S. Virgin Islands has potential commercial wind energy resources, but finding the large sites needed for utility-scale projects on the islands has been a challenge. The most promising locations for utility-scale wind projects are on high ridges and exposed capes. Wind data collected in 2012 and 2013 at potential sites around Longford on St. Croix and the Bovoni Peninsula on St. Thomas found wind speeds suitable for large turbines that could play a meaningful part in helping the U.S. Virgin Islands meet its $60 \%$ by 2025 goal. The Virgin Islands Water and Power Authority, in conjunction with the Virgin Islands Energy Office, completed wind studies to determine the economic feasibility of wind power development in the territory. As of July 2015, the Water and Power Authority is negotiating with several qualified facilities proposing wind projects that were approved by the Public Services Commission pursuant to the Cogeneration and Small Power Production Act. The size of the proposed wind farm is 7 to $10.5 \mathrm{MW}$. 


\section{Midwest Wind Energy Center}

The Midwest Wind Energy Center (MWEC) worked with NREL researchers to provide the following assessment of the state of the wind industry in this region.

The MWEC ${ }^{16}$ serves the following states: Illinois, Indiana, Iowa, Michigan, Minnesota, Missouri, eastern Montana, North Dakota, Ohio, South Dakota, and Wisconsin. The MWEC's main organizer is Windustry. Other key players are the Iowa Wind Energy Association and Tom Wind of Wind Utility Consulting. The following section provides an overview of the wind industry in the region.

The MWEC states have different levels of wind resources (Figure 6). The states in the western portion of the region (Montana, the Dakotas, Iowa, and western Minnesota) have strong, worldclass winds and vast rural areas. The states in the eastern portion of the region (Ohio, Missouri, Indiana, and Michigan) have moderate and low wind resources. Additionally, some states (Illinois, Ohio) have dense populations in some of their windiest areas and are limited in the extent of their land-based development (assuming 80-m hub heights).

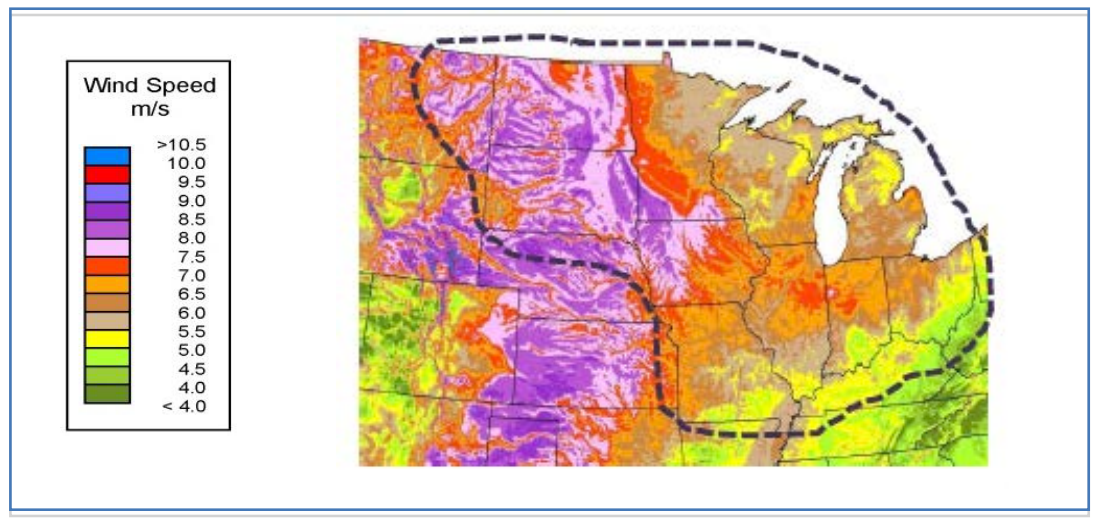

Figure 6. MWEC footprint and average wind speeds at 80 meters

Eight of the states in the MWEC region are in the top 20 nationally in installed wind capacity, and four MWEC states have 15\% or higher in-state wind generation. The MWEC region is a strong national leader in distributed wind, defined as wind turbines of any size serving local loads, on either side of the meter, the retail customer side for on-site load or the wholesale side for large loads nearby.

Overall, the states in this region have vastly different energy demands, with many existing energy plants in transition. This region has historically relied heavily on central station coal and nuclear plants for most of its electricity generation. These plants are aging, and other energy sources such as wind and solar are abundant locally.

The energy demand of the most populous state, Illinois, is spurring development of dedicated transmission for renewable energy. Two large transmission projects dedicated to addressing wind generation in the MWEC region are currently in the planning process. One project is the Rock

${ }^{16}$ http://www.midwestwindenergycenter.org/ 
Island Clean Line, a 500-mile overhead direct current transmission line that will deliver 3,500 MW from northwest Iowa and the surrounding region to communities in Illinois and other states to the east. Another planned project is the Grain Belt Express Clean Line, a 750-mile direct current transmission line that will connect the rich wind resources of Kansas to Missouri, Illinois, Indiana, and markets farther east.

Table 6. Key Statistics for the Midwest Wind Energy Center Region

\begin{tabular}{|c|c|c|c|c|c|c|c|c|c|c|c|}
\hline & IL & IN & IA & MI & MN & MO & $\mathrm{MT}^{17}$ & ND & $\mathrm{OH}$ & SD & WI \\
\hline $\begin{array}{l}\text { Installed Wind, } \\
2015(\mathrm{MW})^{18}\end{array}$ & 3,842 & 1,895 & 6,212 & 1,531 & 3,235 & 459 & 665 & 2,143 & 443 & 977 & 648 \\
\hline $\begin{array}{l}\text { Percentage of } \\
\text { Energy } \\
\text { Supplied by } \\
\text { Wind Projects, } \\
2014\end{array}$ & $5 \%$ & $3 \%$ & $29 \%$ & $2 \%$ & $16 \%$ & $1 \%$ & $6.5 \%$ & $16 \%$ & $.8 \%$ & $21 \%$ & $2 \%$ \\
\hline $\begin{array}{l}\text { Projected } \\
\text { Potential } \\
\text { Capacity (MW), } \\
80 \text { m, } 30 \% \text { CF }\end{array}$ & 249,882 & 148,228 & 570,714 & 59,042 & 489,271 & 274,355 & 944,004 & 770,196 & 54,920 & 882,412 & 103,757 \\
\hline $\begin{array}{l}\text { Projected } \\
\text { Potential } \\
\text { Capacity (MW), } \\
100 \text { m, 30\% CF }\end{array}$ & 329,618 & 183,832 & 601,957 & 179,056 & 603,427 & 399,635 & $1,012,355$ & 771,791 & 123,328 & 890,626 & 215,447 \\
\hline $\begin{array}{l}\text { Contribution } \\
\text { from Distributed } \\
\text { Wind Projects, } \\
2014 \text { (MW) }\end{array}$ & 21.7 & 8.5 & 121.2 & 4 & 125.4 & 7.6 & 4.9 & 8.1 & 37.3 & 3.2 & 26.4 \\
\hline $\begin{array}{l}\text { Proposed } \\
\text { Offshore Wind } \\
\text { Projects (MW) }\end{array}$ & 0 & 0 & 0 & 0 & 0 & 0 & 0 & 0 & $27^{20}$ & 0 & 0 \\
\hline
\end{tabular}

\subsection{Renewable Portfolio Standards}

In the MWEC region, eight states have an RPS (Illinois, Iowa, Michigan, Minnesota, Missouri, Montana, Ohio, and Wisconsin) and three states have a renewable energy goal (Indiana, North Dakota, and South Dakota).

\footnotetext{
${ }^{17}$ Montana is divided between two RRCs: Northwest Wind Resource and Action Center (western Montana) and Midwest Wind Energy Center (eastern Montana). For this report, each RRC provided data for the entire state. ${ }^{18} 2015$ Year End Wind Power Capacity Map. Available at http://apps2.eere.energy.gov/wind/windexchange/wind installed_capacity.asp

${ }^{19}$ Distributed wind project installed capacity is defined as 2003-2014 cumulative capacity (DOE 2015a).

${ }^{20}$ On Lake Erie
} 
Table 7. RPS Overview for Midwest Wind Energy Center States

\begin{tabular}{ll}
\hline & RPS \\
\hline Illinois & $25 \% \times 2026$ \\
Indiana & Clean Energy Portfolio Goal of $15 \% \times 2025$ \\
\hline lowa & IOUs must contract for a total of $105 \mathrm{MW}$ of renewables \\
Michigan & $10 \% \times 2015$ \\
Minnesota & $26.5 \% \times 2025$ (investor-owned utilities) \\
& $31.5 \% \times 2020$ (Xcel) \\
& $25 \% \times 2025$ (other utilities) \\
Missouri & $15 \% \times 2021$ \\
Montana & $15 \% \times 2015$ \\
North Dakota & Goal of $10 \% \times 2015$ \\
Ohio & $12.5 \% \times 2026$, but frozen at 2014 level of 2.5\% until 2017 \\
South Dakota & Goal of $10 \% \times 2015$ \\
Wisconsin & $10 \% \times 2015$ \\
\hline
\end{tabular}

\subsection{Workforce Development}

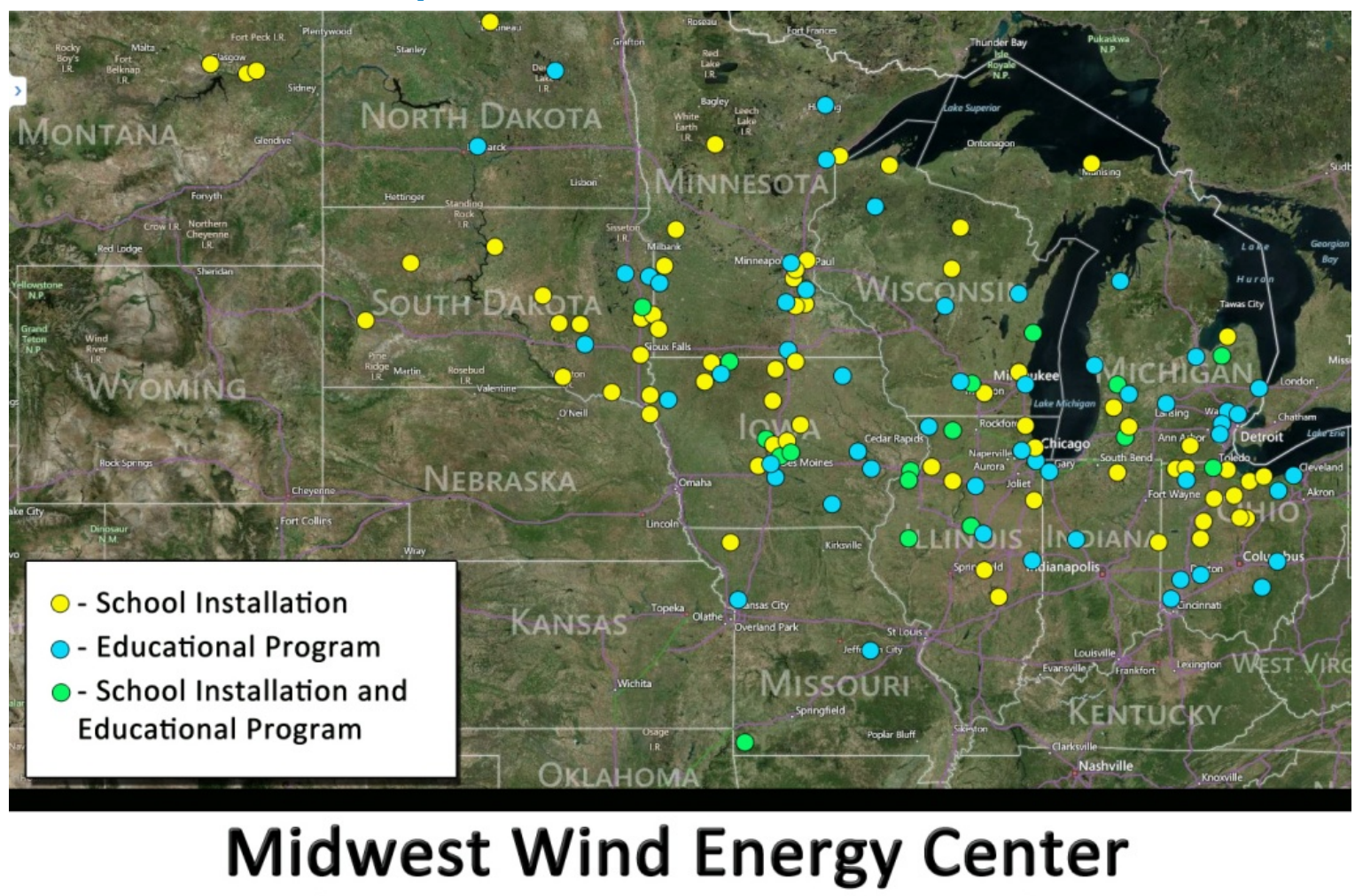

(Eastern MT, ND, SD, MN, IA, MO, WI, IL, IN, MI, OH)

Figure 7. Map of school wind turbine projects, educational programs, and locations with both wind turbines and educational programs within the Midwest Wind Energy Center's area

Educating the future generations of wind energy technicians, engineers, and stakeholders plays a key role in developing the domestic wind workforce. Iowa Lakes Community College was one of the first in the country to offer a wind technician training program and has been providing wind energy education since 2003. Now several community colleges and universities in the 
Midwest offer wind energy training and education. Figure 7 shows the school installations and educational programs for wind energy in the MWEC area. Educational activities are described in more detail in the state sections below. The WINDExchange website also offers information and interactive maps regarding workforce development, the DOE's Collegiate Wind Competition, the DOE's Wind for Schools project, school wind project locations, and locations of education and training programs in the MWEC region and other states. ${ }^{21}$

\subsection{Manufacturing}

NREL researchers compiled the following wind energy manufacturing data for this region as part of DOE's annual wind market report effort (DOE 2015c). Tier I represents major components such as blades and towers, and Tier II components are sub-components, such as inverters and electrical equipment, to make the Tier I equipment.

Table 8. Wind-Related Manufacturing Overview for Midwest Wind Energy Center States

\begin{tabular}{|c|c|c|c|c|}
\hline Name & City & State & Component & Tier \\
\hline Winergy Drive Systems & Elgin & IL & Gear drive & I \\
\hline Siemens/Winergy & Elgin & IL & Gear drive & I \\
\hline Brad Foote Gear Works & Cicero & $\mathrm{IL}$ & Power transmission gears & II \\
\hline HYDAC & $\begin{array}{l}\text { Glendale } \\
\text { Heights }\end{array}$ & IL & Hydraulics, brake systems & II \\
\hline Finkl and Sons & Chicago & IL & Components & II \\
\hline Centa Corp. & Aurora & $\mathrm{IL}$ & Couplings & II \\
\hline Deublin Company & Waukegan & IL & $\begin{array}{l}\text { Slip rings, hydraulic } \\
\text { components }\end{array}$ & II \\
\hline R\&W America & Bensenville & $\mathrm{IL}$ & Couplings & II \\
\hline $\begin{array}{l}\text { Stanley Machining \& } \\
\text { Tool Corp. }\end{array}$ & Carpentersville & IL & $\begin{array}{l}\text { Gear cases, torque arms, } \\
\text { planetary carriers }\end{array}$ & II \\
\hline $\begin{array}{l}\text { Randack Fasteners } \\
\text { America }\end{array}$ & Lake Zurich & IL & Bolts & II \\
\hline SMF & Minonk & IL & $\begin{array}{l}\text { Embed rings, template } \\
\text { rings }\end{array}$ & II \\
\hline $\begin{array}{l}\text { Chicago Industrial } \\
\text { Fasteners }\end{array}$ & West Chicago & IL & Blade studs & II \\
\hline Trinity Structural Towers & Clinton & $\mathrm{IL}$ & Towers & 1 \\
\hline $\begin{array}{l}\text { Carlisle Industrial Brakes } \\
\text { and Friction }\end{array}$ & Bloomington & IN & Brakes & II \\
\hline Oerlikon Fairfield & Lafayette & IN & Gears & II \\
\hline Brevini & Yorktown & IN & Gearbox & II \\
\hline ATI Casting & LaPorte & IN & Component castings & II \\
\hline $\begin{array}{l}\text { Bedford Machine and } \\
\text { Tool }\end{array}$ & Bedford & IN & Rotor hubs and plates & II \\
\hline Siemens & Fort Madison & IA & Blades & 1 \\
\hline Goian North America & Ankeny & IA & Elevation systems & II \\
\hline D.A.D. Manufacturing & Hiawatha & IA & $\begin{array}{l}\text { Walkways, doors, } \\
\text { components }\end{array}$ & II \\
\hline D.A.D. Manufacturing & Lisbon & IA & $\begin{array}{l}\text { Walkways, doors, } \\
\text { components }\end{array}$ & II \\
\hline Trinity Structural Towers & Newton & IA & Towers & I \\
\hline Acciona & West Branch & IA & Turbines & I \\
\hline Energetx & Holland & MI & Blades & 1 \\
\hline
\end{tabular}

${ }^{21}$ http://apps2.eere.energy.gov/wind/windexchange/schools/ 


\begin{tabular}{|c|c|c|c|c|}
\hline Name & City & State & Component & Tier \\
\hline Genzink Steel & Holland & $\mathrm{Ml}$ & Generator frames & II \\
\hline Ventera Wund & Duluth & MI & Distributed wind & I \\
\hline $\begin{array}{l}\text { Wind Turbine Industries } \\
\text { Corp. }\end{array}$ & Prior Lake & MI & Distributed wind & I \\
\hline Citation Corporation & Novi & MI & $\begin{array}{l}\text { Gearbox covers and } \\
\text { housings }\end{array}$ & II \\
\hline $\begin{array}{l}\text { Three M Tool and } \\
\text { Machine }\end{array}$ & Commerce & MI & $\begin{array}{l}\text { Gearbox housings and } \\
\text { forward housings }\end{array}$ & II \\
\hline Akebono Corp & $\begin{array}{l}\text { Farmington } \\
\text { Hills }\end{array}$ & MI & Brakes & II \\
\hline $\begin{array}{l}\text { K\&M Machine } \\
\text { Fabricating }\end{array}$ & Cassopolis & MI & Hub and gearbox housings & II \\
\hline $\begin{array}{l}\text { Great Lakes Gear } \\
\text { Technology }\end{array}$ & Canton & MI & Gears & II \\
\hline ATI Castings & Alpena & MI & Castings & II \\
\hline Dowding Industries & Eaton Rapids & MI & $\begin{array}{l}\text { Transmission housings, } \\
\text { components }\end{array}$ & II \\
\hline Ideal Fabricators & Livonia & MI & Components & II \\
\hline Dokka & Auburn Hills & MI & Fasteners & II \\
\hline Ventower & Monroe & MI & Towers & I \\
\hline $\begin{array}{l}\text { Columbia Gear } \\
\text { Corporation }\end{array}$ & Avon & $\mathrm{MN}$ & Gears & II \\
\hline Zero-Max & Plymouth & $\mathrm{MN}$ & Couplings & II \\
\hline Millwood Metal Works & Freeport & $\mathrm{MN}$ & $\begin{array}{l}\text { Embed rings, template } \\
\text { rings, forms }\end{array}$ & II \\
\hline Remelle Engineering & Big Lake & $\mathrm{MN}$ & Machine castings & II \\
\hline $\begin{array}{l}\text { Continental Disc } \\
\text { Corporation }\end{array}$ & Liberty & MO & Brakes & II \\
\hline Gasket Engineering & Kansas City & MO & Blade components & II \\
\hline FAG Bearings & Joplin & MO & Bearings & II \\
\hline Vest-Fiber & Moberly & MO & Components & II \\
\hline LM Wind Power & Grand Forks & ND & Blades & I \\
\hline Trinity Structural Towers & West Fargo & ND & Towers & I \\
\hline Federal Gear & Willoughby & $\mathrm{OH}$ & Gears & II \\
\hline Advanced Manufacturing & Cleveland & $\mathrm{OH}$ & Gearboxes & II \\
\hline Horsburgh and Scott & Cleveland & $\mathrm{OH}$ & Gears & II \\
\hline Swiger Coil Systems & Cleveland & $\mathrm{OH}$ & Generators & II \\
\hline Parker Hannifin Corp. & $\begin{array}{l}\text { Mayfield } \\
\text { Heights }\end{array}$ & $\mathrm{OH}$ & $\begin{array}{l}\text { Hydraulic components, } \\
\text { brakes }\end{array}$ & II \\
\hline HPM America & Mount Gilead & $\mathrm{OH}$ & $\begin{array}{l}\text { Hubs, bases, generator } \\
\text { frames }\end{array}$ & II \\
\hline Minster Wind & Minster & $\mathrm{OH}$ & $\begin{array}{l}\text { Machine castings, } \\
\text { components }\end{array}$ & II \\
\hline Hamby Young & Aurora & $\mathrm{OH}$ & Substations & II \\
\hline Rotek Inc. & Aurora & $\mathrm{OH}$ & Slew bearings & II \\
\hline Kaydon Bearing & Avon & $\mathrm{OH}$ & Bearings & II \\
\hline Kalt Manufacturing & $\begin{array}{l}\text { North } \\
\text { Ridgeville }\end{array}$ & $\mathrm{OH}$ & Large components & II \\
\hline Magna Machine & Forest Park & $\mathrm{OH}$ & Rotor hubs, support bases & II \\
\hline Cast Fab & Cincinnati & $\mathrm{OH}$ & $\begin{array}{l}\text { Ductile iron component } \\
\text { castings }\end{array}$ & II \\
\hline Canton Drop Forge & Canton & $\mathrm{OH}$ & Gear blanks & II \\
\hline Byrne Manufacturing & Mansfield & $\mathrm{OH}$ & Speed increasers & II \\
\hline Dyson Corp. & Painseville & $\mathrm{OH}$ & Fasteners & II \\
\hline
\end{tabular}




\begin{tabular}{|c|c|c|c|c|}
\hline Name & City & State & Component & Tier \\
\hline Eaton Corp. & Cleveland & $\mathrm{OH}$ & Electrical & II \\
\hline $\begin{array}{l}\text { CMC/BMC Utility } \\
\text { Products }\end{array}$ & Hamilton & $\mathrm{OH}$ & $\begin{array}{l}\text { Power transmission } \\
\text { components }\end{array}$ & II \\
\hline EGC Enterprises & Chardon & $\mathrm{OH}$ & Fasteners & II \\
\hline Tuf-Tug Products & Moraine & $\mathrm{OH}$ & Fall protection gear & II \\
\hline The Benjamin Company & Put-In-Bay & $\mathrm{OH}$ & $\begin{array}{l}\text { Power transmission } \\
\text { components }\end{array}$ & II \\
\hline Milacron Inc & Mount Orab & $\mathrm{OH}$ & Component & II \\
\hline $\begin{array}{l}\text { The American Tank and } \\
\text { Fabricating Company }\end{array}$ & Cleveland & $\mathrm{OH}$ & $\begin{array}{l}\text { Power transmission } \\
\text { components }\end{array}$ & II \\
\hline Elyria Foundry & Elyria & $\mathrm{OH}$ & Component castings & II \\
\hline Edco Inc. & Toledo & $\mathrm{OH}$ & $\begin{array}{l}\text { Power transmission } \\
\text { machining }\end{array}$ & II \\
\hline Molded Fiber Glass & Aberdeen & SD & Blades & I \\
\hline Marmen & Brandon & SD & Towers & I \\
\hline Merit Gear & Antigo & WI & Gears & II \\
\hline $\begin{array}{l}\text { Milwaukee Gear } \\
\text { Company }\end{array}$ & Milwaukee & WI & Gears & II \\
\hline $\begin{array}{l}\text { MAG Giddings and } \\
\text { Lewis }\end{array}$ & Fond du Lac & WI & $\begin{array}{l}\text { Turbine housing, gearbox, } \\
\text { bearings }\end{array}$ & II \\
\hline Ingeteam & Milwaukee & WI & Generators & II \\
\hline Lindquist Machine & Green Bay & WI & $\begin{array}{l}\text { Gearbox, pitch linkage, } \\
\text { main shafts, gearbox } \\
\text { rebuilds }\end{array}$ & II \\
\hline Avanti Wind Systems & New Berlin & WI & Fall protection & II \\
\hline Plexus & Neenah & WI & Electronic components & II \\
\hline Bassett Mechanical & Kaukauna & WI & $\begin{array}{l}\text { Embed rings, template } \\
\text { rings, forms }\end{array}$ & II \\
\hline Broadwind & Manitowoc & WI & Towers & 1 \\
\hline
\end{tabular}

\subsection{Key Stakeholder Groups and Deployment Challenges}

The MWEC targets these stakeholder groups:

- Engaged citizens, including those impacted by existing or planned wind power projects, members of local energy committees, and community organizations either supportive of or concerned about wind energy impacts

- Other stakeholders: educators, students, media, and members of the general public interested in learning more about wind energy

- Policy makers, including regulators, legislators, and administrators

- Policy implementers, including state, regional, and local regulatory/planning authorities, health department, municipal officials (e.g., planning board, economic development, etc.), siting and permitting officials and staff

- Utility representatives: municipal and investor-owned utilities

- Wind development community: developers, manufacturers, scientists.

The information provided to these stakeholder groups addresses the following wind energy deployment market barriers that are prevalent in this region: 
- Transmission issues

- Permitting

- Zoning and legislative issues

- Public acceptance and siting issues

- Poor understanding of wind energy's economic impacts

- Limited understanding of and support for manufacturing

- State and regional competition

- Need for education and engagement of rural populations

- Limited financing and funding for small/community/distributed wind

- Issues with developing on Native lands

- Environmental issues and limitations.

\subsection{Collaborating Organizations}

Organizations that have collaborated with the MWEC include:

- American Wind Energy Association

- Distributed Wind Energy Association

- eFormative Options

- Energy and Environmental Research Center

- Great Lakes Wind Collaborative / Great Lakes Commission

- Green Energy Ohio

- Illinois Institute for Rural Affairs at Western Illinois University

- Illinois State University

- IndianaDG

- Intertribal Council on Utility Policy

- Iowa Economic Development Authority

- Iowa Energy Center

- Iowa Environmental Council

- Iowa Lakes Community College

- Iowa State University
- Iowa Wind Energy Association

- Juhl Energy

- Lawrence Berkeley National Laboratory

- Midwest Renewable Energy Association

- Missouri Energy Initiative

- Montana Department of Commerce

- Navigant

- North Dakota Alliance for Renewable Energy

- Ohio Environmental Council

- RENEW Wisconsin

- Sand Creek Winds

- Small Wind Certification Council

- South Dakota Renewable Energy Association

- South Dakota Wind Energy Association

- Wind on the Wires. 


\subsection{State Updates}

Due to the location of the East-West grid intertie, wind energy engagement in eastern Montana is covered by the MWEC while the Northwest Wind Resource and Action Center addresses engagement in the western part of the state. Since more of the state is covered under the western market, discussion of the Montana market is included in Section 6 of this document.

\subsubsection{Illinois}

Illinois has 3,842 MW of wind installed at the end of 2015 (WINDExchange 2016) with some new projects planned. A notable development is the Kankakee Wind Farm, a 175-MW project developed to supply Microsoft with electricity.

Illinois has several geographic advantages for wind. It has a strong wind resource located near urban centers and can take advantage of exporting energy to eastern markets through PJM Interconnection. However, wind also faces competition from a powerful nuclear sector.

The state has an ambitious RPS of $25 \%$ renewables by 2025 . Nevertheless, there are financial complexities in the utility market in Illinois that have caused the state to be at high risk to not meet this standard. An unintended consequence of the deregulation of electric utilities in Illinois rendered the current RPS "toothless." Therefore, fixing the RPS continues to be a top priority for the wind industry. Although the Illinois General Assembly has not taken up any major energy legislation this year, an energy bill is possible in the near future because Exelon has a large nuclear plant in Illinois and has asked for state financial support.

Illinois is also participating in the Wind for Schools project, through the engagement of Western Illinois University, with seven school systems installed in the state.

\subsubsection{Indiana}

Indiana has 1,895 MW of wind installed at the end of 2015 (WINDExchange 2016), which reflects $200 \mathrm{MW}$ brought online in 2014 by the Headwaters Wind Farm in Randolph County. A major new development for 2015 is the Amazon Wind Farm (Fowler Ridge), a 150-MW project developed to supply Amazon Web Services data centers.

A positive policy development for small wind occurred in Indiana this past legislative session. NIPSCO, an investor-owned utility, agreed to extend its successful voluntary feed-in tariff program, which will facilitate more small wind in northern Indiana.

Indiana is one of three states in the MWEC region with a modest renewable energy goal (10\% by 2015) that is voluntary.

\subsection{3 lowa}

Iowa has 6,212 MW of wind installed at the end of 2015 (WINDExchange 2016). Iowa ranks second in the nation for installed capacity (American Wind Energy Association 2015n). One of the primary reasons for this high ranking is that Iowa is the headquarters of Mid-American Energy Utility, an investor-owned utility primarily owned by Warren Buffet, a vocal supporter of wind energy. While state policy in Iowa has played a role in supporting wind development, Mid- 
American's investment literally changed the farming landscape as well as the state's energy landscape.

In addition to the strong industry players, Iowa has an exceptionally strong wind resource and is in a good location along the electrical grid to export electricity to eastern markets. It also enjoys high public acceptance and support from government leaders.

Iowa is already producing more electricity than the state needs. The recent and future huge growth in wind capacity means that Iowa will eventually need increased transmission lines to continue exporting its power. Experts predict that nearby states will rely on Iowa to help them meet new federal carbon emissions regulations; they will purchase Iowa's clean energy exports to use as credits to reach their own Clean Power Plan targets.

Iowa is home to several wind education programs, including those at Iowa State University and the University of Iowa. Iowa Lakes Community College was one of the first colleges in the country to offer a wind technician training program.

\subsubsection{Michigan}

Michigan has 1,531 MW of wind installed (WINDExchange 2016). If offshore policy and technology advance, Michigan has good potential for offshore wind development. An important development in 2015 was the completion of a new high-voltage transmission line to serve the wind turbines in Michigan's thumb region. ITC Transmission built this line to enable growth in the renewable energy market.

However, wind developers face obstacles in Michigan. One barrier is the uncertainty of dealing with unreceptive local governments because most zoning is decided at the township level. A second barrier is that the state's RPS was challenged; although the challenge was not successful, it resulted in uncertainty in the market.

A recent statewide change is the new agency created by Governor Snyder via executive order: Michigan Agency for Energy. This agency will be housed under the Department of Licensing and Regulatory Affairs and will absorb the current Michigan Energy Office. A key task of the Michigan Agency for Energy will be to focus on coordinating efforts to replace the state's coal power plants with cleaner energy sources.

\subsubsection{Minnesota}

Minnesota has 3,235 MW of wind installed at the end of 2015 (WINDExchange 2016). It also has just more than $125 \mathrm{MW}$ of distributed wind installed, which is the highest in the MWEC region. Minnesota began the 21st century as a leader in Midwestern wind, but even with several new projects planned, Minnesota's wind development has slowed in recent years.

Minnesota has a strong wind resource in the southwestern part of the state and enjoys relatively high public acceptance. Although the state historically has had receptive leadership and policies conducive to wind development, all new energy policy updates were stalled during the most recent legislative session. 
The ongoing CapX2020 transmission line project may increase renewable energy in the near future. Two CapX2020 high-voltage transmission lines, the Brookings County-Hampton and Fargo-St. Cloud-Monticello lines, were energized in early 2015.

\subsubsection{Missouri}

Missouri has $459 \mathrm{MW}$ of wind installed at the end of 2015 (WINDExchange 2016). No new wind projects are planned, and the installed capacity has remained the same for several years. Missouri has a strong but underutilized wind resource in the northwestern part of the state.

Missouri gets most of its energy by importing coal. Eighty-two percent of Missouri's electricity comes from coal, nearly all of it shipped from Wyoming. However, Missouri has the potential to increase its energy independence and could even create its own renewable energy export industry. The 2015 Wind Vision Report suggests that Missouri could vastly increase its installed wind capacity in the coming decades and could produce as much wind energy as Minnesota and the Dakotas.

New solar initiatives moving forward in Missouri may lead the way to more in-state renewable energy development.

\subsubsection{North Dakota}

North Dakota has 2,143 MW of wind capacity installed at the end of 2015 (WINDExchange 2016). North Dakota has been involved in several multi-state transmission projects in recent years, including one that was completed in 2014 (American Wind Energy Association 2015m). New projects have been aided by 2015 legislation that extended wind tax credits. North Dakota has a very strong wind resource, but the state's leaders have been primarily focused on the economic benefits of traditional sources of energy. The state's renewable energy goal (10\% by 2015 ) is voluntary. Wildlife impacts pertaining to sage grouse, bats, and a variety of avian species remain a concern in the state.

\subsubsection{Ohio}

Ohio has $443 \mathrm{MW}$ of wind installed at the end of 2015 (WINDExchange 2016), which is the lowest in the MWEC region. However, it also has more than $37 \mathrm{MW}$ of distributed wind installed in 2014, which is the third highest in the region. Wind energy development continues to move forward in the state with the 250-MW Northwest Ohio wind project. DOE continues to provide support for the six-turbine, 18-MW Icebreaker pilot project on Lake Erie. The installation will likely be the nation's first freshwater offshore wind farm. The Lake Erie Energy Development Corporation began taking core samples in September 2015 and has performed extensive resource assessment and engineering analysis work for the project (Funk 2015).

Ohio has a strong manufacturing sector, which can produce many renewable energy jobs, and it could host offshore wind projects if current technology improves. However, the state's leadership has discouraged new wind developments through public policy. In 2014, Ohio became the first state in the nation to freeze its RPS and energy efficiency standards. It also drastically increased setback requirements for large wind turbines. While these changes are in effect, they make it nearly impossible for developers to build any new wind farms in Ohio. 
Case Western Reserve University in Cleveland has developed a strong offshore wind education collaborative with the Lake Erie Energy Development Corporation offshore wind project.

\subsubsection{South Dakota}

Although South Dakota has only 977 MW of wind installed at the end of 2015 (WINDExchange 2016), the state has a very strong wind resource that has been developed without extensive state policy legislation: it is the only state in the region without a net metering policy, and its renewable energy goal (10\% by 2015$)$ is voluntary. South Dakota has an uncompetitive tax rate on wind compared to surrounding states, but tax rates were adjusted in a new bill passed in 2015 . This bill reduced state taxes on wind to the levels of neighbors North Dakota and Minnesota to be more competitive.

A significant project is underway in South Dakota involving a partnership of Native American tribes. Eight Sioux tribes plan to jointly develop their wind resources. The resulting enterprise has the potential to build one of the largest utility-grade wind installations in the country, generating more than a gigawatt of power, and will provide economic self-sufficiency and political self-determination for the tribes, which occupy the poorest counties in the United States.

South Dakota participates in the DOE's Wind for Schools project, with South Dakota State University helping to install six school systems in the state.

\subsubsection{Wisconsin}

Wisconsin has $648 \mathrm{MW}$ of wind installed at the end of 2015 (WINDExchange 2016) with no new projects under construction. Coal is the state's main source of energy, and there are plans to increase it.

Although the state has strong laws on wind siting and is well positioned for transmission to load centers, it suffers from weak public acceptance. Individual counties have even defied state regulations on siting. In 2014, Brown County declared wind turbines a health hazard. The state has dedicated public funding for a study of health issues related to wind turbines and plans to include documentation from sources that have not been peer reviewed. Concerns regarding bats and other wildlife also continue to impact development in the state. Wisconsin had a healthy small and distributed wind sector through 2012, but both markets have slowed down considerably in recent years (U.S. Department of Energy 2015a).

University of Wisconsin-Madison is participating in the DOE 2016 Collegiate Wind Competition. 


\section{Northeast Wind Resource Center}

The Northeast Wind Resource Center (NWRC) worked with NREL researchers to provide the following assessment of the state of the wind industry in this region.

The NWRC ${ }^{22}$ encompasses the following states: Connecticut, Maine, Massachusetts, New Hampshire, New Jersey, New York, Pennsylvania, Rhode Island, and Vermont. ${ }^{23}$ The NWRC spans offshore and land-based wind energy development at the commercial and community scale through interstate cooperation, information sharing, education, stakeholder engagement, knowledge transfer, and community dialogue. Clean Energy Group leads the offshore wind work; Sustainable Energy Advantage, LLC leads the land-based wind work; and the Maine Ocean and Wind Industry Initiative serves as a key liaison between the project and the wind industry. The NWRC is built on the foundation of previous stakeholder engagement and educational activities, including the New England Wind Energy Education Project, the New England Wind Forum, and current projects such as the Offshore Wind Accelerator Project. ${ }^{24}$

The challenges and opportunities for wind energy development in the region vary from state to state. In addition, land-based wind and offshore wind face different challenges. Land-based wind's biggest challenges across the region are public acceptance and project siting, while offshore wind's major challenges include cost, infrastructure, regulatory barriers, and public acceptance.

Because of the Northeast's demographics, population density, and land-use and ownership patterns, community-scale and larger installations face unique challenges to development. An increasing number of communities across the region are adopting strict zoning regulations or outright bans on land-based commercial wind installations. When doubt and uncertainty enter the debate, decision-makers usually revert to the status quo (no wind project). Many factors are contributing to land-based wind project delays or terminations, including systematically deployed opposition efforts that often derail projects in preliminary stages. Projects that progress beyond initial proposals are all subject to significant hurdles due to permitting appeals and lawsuits. Other factors contributing to declines in wind development include transmission constraints, lack of power purchase agreements, and federal tax policy. The factors make siting projects, even appropriately located ones, progressively more challenging. Developers, some with long-term power purchase agreements, are stepping away from some proposed projects. Development in Maine and Pennsylvania is the exception to this northeast land-based wind development story. Maine has a good amount of wind development potential in the northern, lower population areas of the state where wind development remains strong with more than 1,500 MW in development. Pennsylvania has less near-term development underway but also has many areas of good wind resource and lower population density.

The high cost of offshore wind energy is a major barrier to its development. Offshore wind projects face high costs due to construction, installation, and operation at sea, as well as the modifications to turbines and foundations for life at sea. Infrastructure barriers include

\footnotetext{
${ }^{22}$ http://www.northeastwindcenter.org/

${ }^{23}$ Island communities in coastal Maine, Massachusetts, and Rhode Island are also part of the Islanded Grid Resource Center region.

${ }^{24}$ http://www.cesa.org/projects/accelerating-offshore-wind-owap/
} 
transmission challenges, lack of deep-water ports, lack of specialized installation vessels, a workforce with limited experience, and a nascent supply chain. Complex permitting, lengthy site selection and leasing processes, and uncoordinated planning (jurisdiction by jurisdiction) pose regulatory challenges. Public acceptance issues and lengthy litigation battles mainly have been an issue in Massachusetts, the proposed site of the Cape Wind Project. The Block Island Wind Farm in Rhode Island initiated offshore construction in the summer of 2015 and will be America's first offshore wind farm. This five-turbine, 30-MW project being developed by Deepwater Wind is expected to go online in 2016.

The following section provides an overview of the wind industry in the region.

Table 9. Key Statistics for the Northeast Wind Resource Center Region

\begin{tabular}{|c|c|c|c|c|c|c|c|c|c|}
\hline & CT & ME & MA & NH & NJ & NY & PA & $\mathbf{R I}$ & VT \\
\hline \multicolumn{10}{|l|}{ Land-Based Wind Projects } \\
\hline $\begin{array}{l}\text { Installed Wind, } 2015 \\
(\mathrm{MW})\end{array}$ & 5 & 613 & 107 & 185 & 9 & 1,749 & 1,340 & 9 & 119 \\
\hline $\begin{array}{l}\text { Proposed Offshore Wind } \\
\text { Projects (MW) }\end{array}$ & & $12^{25}$ & $\begin{array}{l}1,000 \text { w/ RI } \\
\text { (Deepwater } \\
\text { One) }\end{array}$ & & 25 & & & $\begin{array}{c}1,000 \text { w/ MA } \\
\text { (Deepwater } \\
\text { One })^{26}\end{array}$ & \\
\hline $\begin{array}{l}\text { Offshore Wind Projects } \\
\text { Under Construction/ } \\
\text { Permitted (MW) }\end{array}$ & & & & & & & & 30 & \\
\hline $\begin{array}{l}\text { Percentage of Energy } \\
\text { Supplied by Wind Projects, } \\
2014\end{array}$ & $0 \%$ & $7 \%$ & $.6 \%$ & $2 \%$ & $0 \%$ & $3 \%$ & $2 \%$ & $0 \%$ & $3 \%$ \\
\hline $\begin{array}{l}\text { Projected Potential } \\
\text { Capacity (MW), } 80 \text { m, } \\
30 \% \text { CF }\end{array}$ & 27 & 11,251 & 1,028 & 2,135 & 132 & 25,781 & 3,307 & 47 & 2,949 \\
\hline $\begin{array}{l}\text { Projected Potential } \\
\text { Capacity (MW), } 100 \text { m, } \\
30 \% \text { CF }\end{array}$ & 186 & 30,847 & 1,913 & 3,919 & 349 & 57,639 & 7,222 & 84 & 5,637 \\
\hline $\begin{array}{l}\text { Contribution from } \\
\text { Distributed Wind Projects } \\
(\mathrm{MW})^{27}\end{array}$ & .5 & 7.7 & 65.5 & 1.7 & 10.9 & 10.4 & 5.9 & 9.3 & 12 \\
\hline
\end{tabular}

\subsection{Renewable Portfolio Standards}

In the NWRC's region, eight states have an RPS, while Vermont has a Sustainably Priced Energy Enterprise Development Program created to promote renewable energy development. The program is not a renewable portfolio goal or standard. However, the Vermont Legislature recently passed a renewable energy bill that would create a renewable energy standard, requiring utilities to buy and sell renewable electricity beginning in 2017. It is expected that the Governor will sign the legislation into law. In other states, legislative proposals to modify the RPS programs are pending, although it is unclear whether they will be acted on or passed.

\footnotetext{
${ }^{25}$ University of Maine

${ }^{26}$ Block Island

${ }^{27}$ Distributed wind project installed capacity is defined as 2003-2014 cumulative capacity (U.S. Department of Energy 2015a).
} 
Table 10. RPS Overview for Northeast Wind Resource Center States

\begin{tabular}{ll}
\hline & RPS \\
\hline Connecticut & $27 \% \times 2020$ \\
Maine & $30 \% \times 2000$ \\
& New RE: $10 \% \times 2017$ \\
Massachusetts & $22.1 \% \times 2020$ \\
New Hampshire & $24 \%$ annually thereafter) \\
& $20.38 \% 2025$ \\
New Jersey & $+4.1 \%$ Rolar $\times 2021$ \\
New York & $29 \% \times 2015$ \\
Pennsylvania & $18 \% \times 2021$ (include non-renewable alternative resources) \\
Rhode Island & $16 \% \times 2020$ \\
Vermont & $55 \%$ by 2017 and $75 \%$ by 2032 \\
\hline
\end{tabular}

\title{
5.2 Workforce Development
}

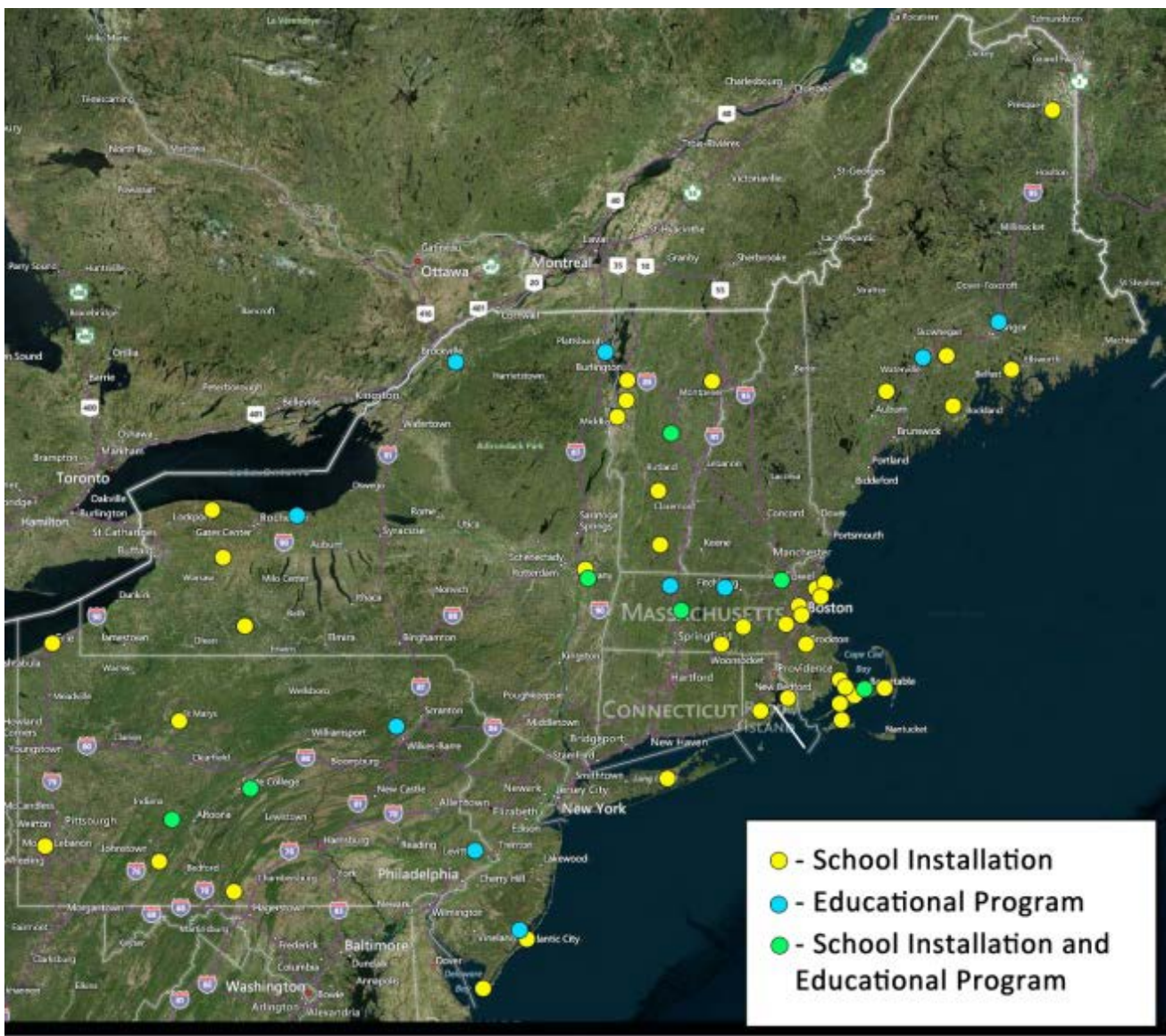

\section{Northeast Wind Resource Center}

\author{
(ME, VT, NH, MA, CT, RI, PA, NY, NJ)
}

Figure 8. Map of school wind turbine projects, educational programs, and locations with both wind turbines and educational programs within the Northeast Wind Resource Center's area 
Several institutions provide wind energy education in the region, including Pennsylvania State University, University of Massachusetts Amherst and Lowell, University of Delaware, University of Maine, Massachusetts Institute of Technology, Cornell University, and Cape Cod Community College. Educational activities are described in more detail in the state sections below. The WINDExchange website also offers information and interactive maps regarding workforce development, the DOE's Collegiate Wind Competition, the DOE's Wind for Schools project, school wind project locations, and locations of education and training programs in the NWRC region and other states. ${ }^{28}$

\subsection{Manufacturing}

NREL researchers compiled the following wind energy manufacturing data for this region as part of DOE's annual wind market report effort (DOE 2015c). Tier I represents major components such as blades and towers, and Tier II components are sub-components, such as inverters and electrical equipment, to make the Tier I equipment.

Table 11. Wind-Related Manufacturing Overview for Northeast Wind Resource Center States

\begin{tabular}{lllll}
\hline Name & City & State & Component & Tier \\
\hline Second Wind & Somerville & MA & $\begin{array}{l}\text { Anemometers, controllers, } \\
\text { sensors }\end{array}$ & II \\
BJA Magnetics & Rutland & MA & Magnetics & II \\
Pika Energy & Westbrook & ME & Distributed wind & I \\
Hendrix Wire and Cable & Milford & NH & Cable systems & II \\
Weaver Wind Energy & Freeville & NY & Distributed wind & I \\
UGE International & New York & NY & Distributed wind & I \\
loxus & Oneonta & NY & Ultracapacitors & II \\
Vacon Inc. & Chambersburg & PA & A/C drives & II \\
Ellwood Group & Irvine & PA & Main shaft bearings & II \\
Eickhoff Corporation & Pittsburgh & PA & Gearbox & I \\
Hodge Foundry & Greenville & PA & Component castings & II \\
Windurance & Seneca & PA & Pitch control systems & II \\
Northern Power & Barre & VT & Distributed wind & I \\
Systems & & & & \\
\hline
\end{tabular}

\subsection{Key Stakeholder Groups and Deployment Challenges}

The NWRC targets these stakeholder groups:

- For offshore wind, the NWRC is focused on state clean energy funds and the public utility commission as its primary stakeholders.

- For land-based wind, the NWRC is focused on state and local policy-makers, media, and members of the public.

- Through its industry partner the Maine Ocean Wind Industry Initiative, some offshore wind outreach is provided to industry stakeholders and the general Maine public.

Information provided to these stakeholder groups addresses wind energy deployment market barriers that are prevalent in this region.

${ }^{28}$ http://apps2.eere.energy.gov/wind/windexchange/schools/ 
- The high costs of offshore wind energy are addressed on a regional basis. Information and outreach is geared toward innovative regional procurement targets, regional financing, alternative financing through green banks and bonds, and regional supply chain development. The Islanded Grid Resource Center reported that island communities in coastal New England choosing to pursue offshore wind projects face challenges including attracting financial investment; lowering the cost of energy produced; navigating the regulatory process; addressing technical issues related to installation, interconnection, and operation; researching and mitigating environmental impacts; interacting with other human uses; and public acceptance. The fact that there are no full-scale offshore wind turbines currently deployed in the United States further complicates many of these challenges, as there are no domestic projects that can serve as examples to inform these topics.

- Information on financing and cost reductions in Europe is shared with stakeholders.

- Information and outreach to the land-based wind stakeholder groups include publications, guidelines, and other materials that can aid sound decision-making when considering new policies or wind project proposals.

- The NWRC is compiling information resources on its website as well as convening a working group that is developing a set of evaluation criteria that can be applied to individual information resources so that stakeholders can discern their suitability for decision-making or journalistic coverage.

- The topics covered in the resource library include wind physiological and environmental impacts, along with technical, economic, financial, and operational issues.

\subsection{Collaborating Organizations}

Organizations that have collaborated with the Northeast Wind Resource Center include:

- Appalachian Mountain Club

- Cape \& Islands Self Reliance

- Consensus Building Institute

- Conservation Law Foundation

- Distributed Wind Energy Association

- Fishermen's Energy

- Great Lakes Wind Collaborative

- Lawrence Berkeley National Laboratory

- Maine Renewable Energy Association

- Massachusetts Clean Energy Center

- Meister Consultants Group

- Metcalf Institute-University of Rhode Island
- Mid-Atlantic Reg. Resource Center

- Natural Resources Council of Maine

- New York State Energy Research and Development Authority

- Renewable Energy Long Island

- Rhode Island Office of Energy Resources

- Small Wind Certification Council

- Southeast Coastal Wind Coalition

- Southern Alliance for Clean Energy

- UMass Wind Energy Center

- Union of Concerned Scientists

- University of Maine 
- Utility Variable-Generation Integration Group
- U.S. Offshore Wind Collaborative

- Vermont Public Service Department.

\subsection{State Updates}

\subsubsection{Connecticut}

At the end of 2015, Connecticut had 5 MW of installed wind capacity (WINDExchange 2016). The state is moving toward initiatives on regional procurement of clean energy resources in collaboration with other states. Connecticut, Massachusetts, and Rhode Island have drafted a request for proposals that utility-scale wind resources would be eligible to respond to. The three states hope to complete the joint procurement process by the end of 2016. In 2014, the approval of wind siting guidelines ended an effective moratorium on wind development.

After a long legal battle, construction began on Connecticut's first commercial wind turbines in the summer of 2015. BNE Energy is developing the Colebrook South Project, which consists of three turbines (Boughton 2015).

\subsubsection{Maine}

With $613 \mathrm{MW}$ of installed wind capacity at the end of 2015 (WINDExchange 2016), Maine is the regional leader in wind power deployment for New England. Wind power provides $8 \%$ of the state's total electricity supply and development of large-scale, onshore projects continues to expand with $276 \mathrm{MW}$ of additional capacity under construction. However, the development of community-scale and offshore wind projects has slowed in recent years due to an unstable political climate and public acceptance issues surrounding sound and aesthetic impacts.

The University of Maine received a $\$ 3$ million DOE grant in May 2014 for its proposed 12-MW floating offshore wind farm. Earlier in 2014, the Maine Public Utilities Commission approved a term sheet for the Aqua Ventus project, calling on the offshore pilot project to sell electricity to Central Maine Power for 23 cents per kilowatt-hour. The University of Maine received additional funding from DOE in 2015 to continue developing its offshore wind project.

\subsubsection{Massachusetts}

At the end of 2015, Massachusetts had $107 \mathrm{MW}$ of installed wind capacity (American Wind Energy Association 2015e). The single project constructed in 2014 was the Lynn Water \& Sewer Commission's 660-kW turbine (American Wind Energy Association 2015m). The project was partially funded through the Massachusetts Clean Energy Center, which continues to support installations in the state through its Commonwealth Wind Program. ${ }^{29}$ Several projects were initiated in 2015 with expected commissioning in 2016, including the 8-MW Future Generation Wind project in Plymouth, Massachusetts (Mass Energy Consumers Alliance 2016).

The Massachusetts Clean Energy Center also approved up to $\$ 1.8$ million in relief assistance for the Town of Falmouth to financially assist the municipality as it attempts to navigate the impacts associated with reduced operations of the town's wind project. Community concerns surrounding

\footnotetext{
${ }^{29}$ http://www.masscec.com/programs/commonwealth-wind-program
} 
sound impacts led to curtailment and unanticipated costs (Massachusetts Clean Energy Center 2014).

The proposed Cape Wind project in Massachusetts was dealt a major blow when the two utilities with power purchase agreements pulled their agreements after Cape Wind failed to obtain financing by the deadline. Without these power purchase agreements, the project cannot be built. Cape Wind brought the utilities' action to court. Most recently, a federal appellate court overturned a lower court's earlier ruling defending Cape Wind's power purchase agreement, representing another potentially lethal setback for the project.

Two federal lease sales in a second Massachusetts Wind Energy Area occurred in January 2015; the leases went to RES Americas and Offshore MW. Both leases were sold much cheaper than other lease areas, possibly due to the deeper water at the site. RES Americas paid \$281,285 for the lease, which covers 760 square kilometers and has the potential to generate more than 1 gigawatt of capacity. DONG Energy, a Danish developer and utility - and the largest offshore wind developer in the world - acquired RES Americas' lease. This is encouraging news for the U.S. offshore wind sector, although DONG is awaiting BOEM approval of the lease transfer.

Massachusetts is part of the three-state initiative for clean energy procurement described in the section on Connecticut.

Massachusetts has a number of wind energy education programs. The University of Massachusetts at Amherst has had an active wind energy program for more than 40 years. The University of Massachusetts at Lowell has also participated in the 2014 Collegiate Wind Competition and is an entrant for the 2016 Competition. University of Massachusetts at Amherst is also an entrant for the 2016 Competition.

\subsubsection{New Hampshire}

New Hampshire had 185 MW installed wind capacity at the end of 2015 (WINDExchange 2016). Projects in the state have faced high levels of opposition, leading to some efforts being abandoned prior to construction. In 2014, Iberdrola announced that it would abandon its Wild Meadows Wind Farm plans, citing the company's recent experience with the Groton Wind Farm and the state's current political and regulatory environments (Morris 2014). Installed in 2012, the Groton Wind Farm has faced continued opposition and hearings due to alleged changes that were made to the project without consent or review by the state's permitting authority (Seufert 2014).

The New Hampshire Legislature passed a bill creating an offshore wind study committee that presented its recommendations to the legislature and Governor. Included in the recommendations to the legislature was a multi-state approach to developing offshore wind and the designation of a BOEM multi-state task force to further explore the offshore wind potential in New Hampshire.

The New Hampshire Site Evaluation Committee developed and released draft siting guidelines, but meanwhile towns continue to pass restrictive wind siting bylaws and moratoria.

\subsubsection{New Jersey}

Onshore and offshore developments have moved slowly in New Jersey, which had 9 MW of land-based installed wind energy at the end of 2014 (American Wind Energy Association $2015 \mathrm{~m}$ ), with that number remaining the same at the end of 2015 (WINDExchange 2016). 
Fishermen's Energy, a proposed five-turbine offshore project that is one of DOE's Offshore Wind Advanced Technology Demonstration Projects, has not received approval from the New Jersey Board of Public Utilities to move forward. In a recent appellate court decision, the court backed the board's rejection of the demonstration project, affirming that Fishermen's Energy had not established the project's financial viability. Fishermen's Energy has been seeking approval to move forward with the project since 2008 .

\subsubsection{New York}

With 1,749 MW of installed wind, New York leads the Northeast in overall wind energy capacity. This amount of development equates to a $\$ 3.4$ billion capital investment for the state. It also provides approximately $\$ 5.2$ million in annual land lease payments (American Wind Energy Association 2015i).

The small and distributed wind markets continue to be active in New York. While the main driver of this has historically been an incentive program provided through the New York State Energy Research and Development Authority, third-party leasing is a new model that is expected to further advance this type of installation. United Wind, a leader in this area, reported that it had five New York projects financed through third-party leasing in 2014. Though this was a slowerthan-expected beginning for the company, 2015 has seen an increase in total projects utilizing this model. As of May 2015, 27 projects had been commissioned using this financing mechanism (U.S. Department of Energy 2015a).

Currently the state is re-designing its overall energy strategy. New York has adopted an aggressive goal of obtaining electricity from renewable sources, with RPS targets aimed at three groups: large-scale generators that sell power to the wholesale grid or in some cases generate power for onsite use; small-scale generators such as a wind turbine at a residence; and other market activities, such as individuals and businesses that choose to pay a premium on their electricity bill to support renewable energy (New York State Energy Research and Development Authority 2015).

New York is also reviewing the planning process for its transmission system, which currently is constrained and is affecting wind development and operation. BOEM hosted public open houses in June 2015 to share visual simulations of potential offshore wind development.

\subsubsection{Pennsylvania}

At the end of 2015, Pennsylvania had 1,340 MW of installed wind capacity. A vast majority of this clean generation comes from 24 wind projects that have been installed across the state. This amount of development equates to a $\$ 2.7$ billion capital investment and provides approximately $\$ 4$ million in annual land lease payments (American Wind Energy Association 2015k). There have been no utility-scale wind farms installed in the state since 2012. Wildlife issues, including wind energy's impact on bats in the state, have hampered development, as have concerns related to sound, health, and property values. Another significant issue for the state is that many of the windiest, undeveloped locations are on state game lands, which thus far are not available for wind project development (S. Stewart, personal interview, December 2015). 
The proposed 2015-2016 budget for the state's Department of Environmental Protection contains bonds that will provide $\$ 20$ million to "increase the state's fleet of wind energy plants" (Pennsylvania Department of Environmental Protection 2015).

In 2004, Pennsylvania established its Alternative Energy Portfolio Standards Act, which requires $18 \%$ of the state's energy to be generated by clean, efficient sources by 2021 (Pennsylvania Public Utility Commission 2016).

Pennsylvania is also participating in the Wind for Schools project through the engagement of Pennsylvania State University and the installation of five school systems. Pennsylvania State University was the winner of the 2014 Collegiate Wind Competition and is an entrant for the 2016 Competition.

\subsubsection{Rhode Island}

Rhode Island finished 2015 with 9 MW of wind energy installed (American Wind Energy Association 2015m). Development on the Block Island 30-MW offshore wind farm continues; construction began in the summer of 2015. Contracts have been secured for turbines, foundations, blades, and more. The project is scheduled to go online in the summer of 2016. The \$225 million project will provide electricity to Block Island and Rhode Island customers. Although project construction has begun, opponents continue to pursue litigation, filing a complaint in August 2015 in the U.S. District Court in an attempt to overturn the project's August 2010 power purchase agreement (Kuffner 2015).

Rhode Island is part of the three-state initiative for clean energy procurement described in the section on Connecticut.

\subsubsection{Vermont}

Vermont's total wind energy capacity was 119 MW at the end of 2014 (American Wind Energy Association 2015o), and that number remains the same at the end of 2015. Issues concerning aesthetics, wildlife (Ring 2015), and property value impacts (Preedom 2015) still prevail in the state, slowing development and leading to community resistance to hosting wind turbines.

The Vermont legislature passed a very aggressive RPS starting at $55 \%$ by 2017 and then increasing by $4 \%$ every 3 years until reaching $75 \%$ by 2032 (DSIRE 2015). Specifics are provided for distributed generation, retail electricity providers, and municipal utilities. While the targets for the program are high, the previously mentioned development challenges will likely limit the opportunities for utility-scale wind to participate. 


\section{Northwest Wind Resource and Action Center}

The Northwest Wind Resource and Action Center worked with NREL researchers to provide the following assessment of the state of the wind industry in this region.

The Northwest Wind Resource and Action Center ${ }^{30}$ encompasses the following states: Idaho, western Montana, Oregon, Washington, and Wyoming. Renewable Northwest Project is the principal investigator. Northwest Sustainable Energy for Economic Development (Northwest SEED) facilitates committee activities related to distributed and community wind. The Oregon Department of Energy leads the offshore wind work. The Commerce Departments of Washington and Montana, along with Boise State University, serve on the steering committee.

All states in the region face barriers related to wildlife and project siting; depressed electric market prices; low natural gas costs; little load growth; and a combination of transmission constraints, a need for balancing area coordination, and better integration services markets. In addition, those states with renewable portfolio standards (Montana, Oregon, and Washington) are seeing decreased market potential as utilities fulfill their near-term target requirements. These factors have slowed the pace for new project development, although a pipeline of approved projects exists once markets improve.

The following section provides an overview of the wind industry in the region.

Table 12. Key Statistics for the Northwest Wind Resource and Action Center Region

\begin{tabular}{|c|c|c|c|c|c|}
\hline & ID & $\mathrm{MT}^{31}$ & OR & WA & WY \\
\hline Installed Wind, $2015(\mathrm{MW})^{32}$ & 973 & 665 & 3,153 & 3,075 & 1,410 \\
\hline $\begin{array}{l}\text { Percentage of Energy Supplied by } \\
\text { Wind Projects, } 2014\end{array}$ & $16 \%$ & $6 \%$ & $12 \%$ & $6 \%$ & $8 \%$ \\
\hline $\begin{array}{l}\text { Projected Potential Capacity (MW), } \\
80 \mathrm{~m}, 30 \% \text { CF }\end{array}$ & 18,076 & 944,004 & 27,100 & 18,479 & 552,073 \\
\hline $\begin{array}{l}\text { Projected Potential Capacity (MW), } \\
100 \mathrm{~m}, 30 \% \mathrm{CF}\end{array}$ & 44,770 & $1,012,355$ & 50,566 & 32,606 & 593,769 \\
\hline $\begin{array}{l}\text { Contribution from Distributed Wind } \\
\text { Projects, } 2014(\mathrm{MW})^{33}\end{array}$ & 2.4 & 4.9 & 4.9 & 12.7 & 5.9 \\
\hline $\begin{array}{l}\text { Proposed Offshore Wind Projects } \\
\text { (MW) }\end{array}$ & & & $30^{34}$ & & \\
\hline
\end{tabular}

\subsection{Renewable Portfolio Standards}

In the Northwest Wind Resource and Action Center's region, Oregon, Washington, and Montana each have an RPS in place.

\footnotetext{
${ }^{30}$ http://nwwindcenter.org/

31 Montana is divided between two RRCs: Northwest Wind Resource and Action Center (western Montana) and Midwest Wind Energy Center (eastern Montana). For reporting purposes, each RRC provides data for the entire state.

322015 Year End Wind Power Capacity Map. Available at http://apps2.eere.energy.gov/wind/windexchange/wind_installed_capacity.asp

${ }^{33}$ Distributed wind project installed capacity is defined as 2003-2014 cumulative capacity (U.S. DOE 2015a).

${ }^{34}$ Principle Power
} 
- In 2005, Montana passed an RPS requiring large investor-owned utilities to acquire $15 \%$ of their energy from new renewable resources by 2015 . Montana utilities will meet the overall 2015 target but will need to add renewable resources in the future to maintain compliance. Montana also has a Community Renewable Energy Project (CREP) provision in the state's RPS that requires utilities to procure a certain amount of nameplate capacity of smaller (less than $25 \mathrm{MW}$ ) locally owned renewable energy projects, either wholly utility-owned or at least 50\% owned by Montana investors. NorthWestern Energy is the only utility with CREP obligation left in Montana and must procure roughly $45 \mathrm{MW}$. Satisfying the CREP requirement has resulted in regulatory and project development challenges in recent years but remains a near-term driver for renewable energy projects in the state. NorthWestern Energy is currently out of compliance with the CREP requirement and is requesting a waiver from the Public Service Commission for the 2014 compliance year.

- The Oregon Renewable Energy Act (SB 838) was signed into law on June 6, 2007. The Act establishes a Renewable Energy Standard that requires Oregon's largest utilities to acquire $25 \%$ of their electricity from renewable energy sources by 2025. Smaller Oregon utilities must meet targets of $5 \%$ or $10 \%$ by 2025 . Oregon utilities have met the 2015 targets but will need to acquire new resources to meet the final 2025 targets.

- In November 2006, Washington voters passed Initiative 937, the Clean Energy Initiative. I937 enacts a renewable energy standard that requires Washington's 17 largest utilities to get $15 \%$ of their electricity from new, homegrown, renewable energy sources by 2020 . Utilities will also be required to pursue all low-cost energy efficiency and conservation opportunities. Washington utilities met their interim 2012 targets. Many utilities will need to acquire additional resources to meet the 2020 target.

Two of the states in the region, Idaho and Wyoming, have no RPS.

Table 13. RPS Overview for Northwest Wind Resource and Action Center States

\begin{tabular}{ll}
\hline & RPS \\
\hline Idaho & None \\
\hline Montana & $15 \%$ by 2015 \\
& Large utilities: $25 \%$ by 2025 \\
& Small utilities: $10 \%$ by 2025 \\
Oregon & Smallest utilities: $5 \%$ by 2025 \\
Washington & $15 \%$ renewables by 2020 \\
Wyoming & None \\
\hline
\end{tabular}




\subsection{Workforce Development}

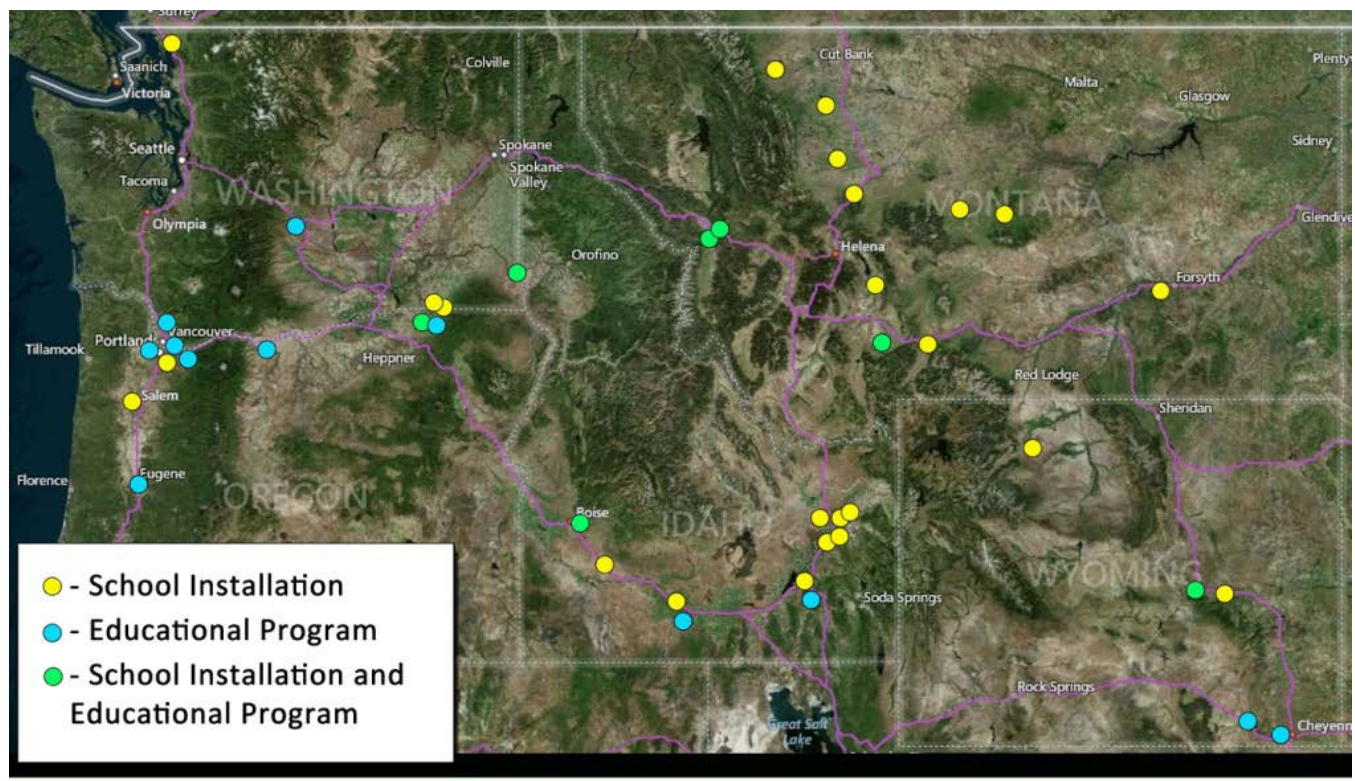

\section{Northwest Wind Resource and Action Center \\ (WA, OR, ID, WY, Western MT)}

Figure 9. Map of school wind turbine projects, educational programs, and locations with both wind turbines and educational programs within the Northwest Wind Resource and Action Center's area

Wind energy educational programs across the Northwest have been limited. Educational activities are described in more detail in the state sections below. The WINDExchange website also offers information and interactive maps regarding workforce development, the DOE's Collegiate Wind Competition, the DOE's Wind for Schools project, school wind project locations, and locations of education and training programs in the Northwest Wind Resource and Action Center's region and other states. ${ }^{35}$

\subsection{Manufacturing}

NREL researchers compiled the following wind energy manufacturing data for this region as part of DOE's annual wind market report effort (DOE 2015c). Tier I represents major components such as blades and towers, and Tier II components are sub-components, such as inverters and electrical equipment, to make the Tier I equipment.

Table 14. Wind-Related Manufacturing Overview for Northwest Wind Resource and Action Center States

\begin{tabular}{lllll}
\hline Name & City & State & Component & Tier \\
\hline XZERES Wind & Wilsonville & OR & Distributed wind & I \\
Moventas & Portland & OR & Gearbox & I \\
PowerClimber Wind & Seattle & WA & Hoist, rigging equipment & II \\
\hline
\end{tabular}

${ }^{35}$ http://apps2.eere.energy.gov/wind/windexchange/schools/ 


\subsection{Key Stakeholder Groups and Deployment Challenges}

The Northwest Wind Resource and Action Center targets these stakeholder groups:

- Bonneville Power Administration

- County commissioners

- Developers

- Educational institutions (academia)

- Experts (researchers, technical)

- Federal agencies

- Federal government (decision makers, elected officials, policy makers)

- Public interest groups (advisory, advocacy, affiliates, boards, committees, community, consumer, councils, NGOs, partner network, working group)

- Industry (manufacturers, supply chain, associated businesses)

- Industry trade groups

- Media

- Merchant energy suppliers

- Non-elected government officials

- Public (engaged citizens, interested and general public)

- Regulatory (public utility commissioners, decision makers, staff, interveners)

- State agencies

- State government (decision makers, elected officials, governor staff, policy makers)

- Tribal

- Utilities (power authorities, publics, munis, co-ops, decision makers, staff)

- Utility trade groups.

The information provided to these stakeholder groups addresses the following wind energy deployment market barriers that are prevalent in this region:

- Need to advance the state-of-the art in resource planning processes and ensure accurate wind information is utilized in utility integrated resource planning

- Need for transmission and energy market advances, including a liquid bilateral market for integration resources, 15-minute scheduling, and development of a regional energy imbalance market

- Need for science-based resource planning in siting guidelines, especially for development in sage grouse areas 
- Need for improved zoning and permitting practices in jurisdictions with high distributed/community wind potential

- Restricted access to capital for distributed/community wind development

- Lack of technical assistance available for potential community wind projects

- Lack of strong baseline of technical information about offshore wind and the need to build credibility around the resource opportunity.

\subsection{Collaborating Organizations}

Organizations that have collaborated with the Northwest Wind Resource and Action Center include:

- American Wind Energy Association

- Beneficial State Bank

- Boise State University

- Columbia Gorge Community College

- Community Renewable Energy Association

- Distributed Wind Energy Association

- DNV GL

- EDP Renewables North America

- eFormative Options

- Endurance Wind Power

- EWT Americas

- Iberdrola Renewables
- Idaho National Laboratory

- McKinstry

- Montana Department of Environmental Quality

- Montana Renewable Energy Association

- Northwest National Marine Renewable Energy Center

- Oregon State University

- Oregon Wave Energy Trust

- Pacific Northwest National Laboratory

- Puget Sound Energy

- Oregon Wave Energy Trust

- Vaisala 3Tier.

\subsection{State Updates}

\subsubsection{Idaho}

As of the end of 2014, Idaho has 33 wind projects with a total installed capacity of $973 \mathrm{MW}$, and that number remained the same at the end of 2015 (WINDExchange 2016). Idaho has a larger percentage of smaller projects compared to neighboring states as many of the wind projects were developed under the Public Utility Regulatory Policies Act (PURPA) limits. The major utility in the state, Idaho Power, has leveraged this to influence policy changes at the Public Utilities Commission that limit project size and make changes to rates for standard PURPA contracts that increase costs for developers. Opponents of wind development have also been very active, including billboard messaging on the I-84 corridor, focusing on areas with high concentrations of wind projects. The political climate has limited the effectiveness of messaging by wind 
proponents in a variety of venues. Idaho has $2.4 \mathrm{MW}$ of distributed wind capacity installed and no community wind projects.

Idaho participates in the Energy Department's Wind for Schools project through the engagement of Boise State University, with the installation of seven school systems in the state. Boise State University also participated in the 2014 Collegiate Wind Competition and is an entrant for the 2016 Competition.

\subsubsection{Montana}

As of the end of 2015, Montana had 17 wind projects with a total installed capacity of $665 \mathrm{MW}$. The state has a large wind resource, ranking third nationally in total wind energy potential, but the lack of transmission capacity to other states inhibits Montana from capturing it. This is especially problematic in eastern Montana, which has the lowest population and the highest wind resource. A growing local opportunity could be the industrial boom in the Bakken region. Ironically, this boom has created a new market of local demand for electricity, which could be supplied by wind. Governor Steve Bullock supports energy development in general, including wind, and holds a fairly conservative stance on carbon regulation, which would benefit wind but also impact Montana's coal industry. Public support is overwhelmingly in favor of wind energy development but at the same time supportive of existing coal generation.

The Montana Public Service Commission currently has a mixed track record on wind energy development. Recently the commission approved a $25 \mathrm{MW}$ negotiated Qualifying Facilities/PURPA wind contract on NorthWestern Energy's system. At the same time, the commission has reduced the standard offer contract terms for new Qualifying Facilities/PURPA wind projects from $10 \mathrm{MW}$ of maximum capacity to $3 \mathrm{MW}$. The Public Service Commission has also complicated proposals for CREPs, though perhaps not primarily because the projects were wind or renewable energy.

Transmission issues make it challenging for Montana to export its power to population centers in other states. The two biggest electric grids in the United States are the Western Connection and the Eastern Connection, and they meet in eastern Montana. However, policy and financial issues make it impractical for eastern Montana to export energy across the grid divide into Washington State. As a result, the strong wind resource potential in eastern Montana is effectively cut off from exporting energy to the West.

While opposition to new transmission lines still exists, improvements to the siting process and some legislative changes have created a more favorable climate over the past few years. In the case of the Mountain States Transmission Intertie line, creating a citizens-based study group helped the average person's voice be heard in the siting process. Unfortunately, market forces have delayed development of the line and other major projects in the region, such as Bonneville Power Administration's Montana-to-Washington project. Planned and potential coal plant retirements may also affect transmission capacity available for wind energy export to certain markets.

Montana has a 15\% by 2015 RPS. Northwestern Energy, the largest utility in the state, will meet the 2015 RPS target mostly through generation from seven wind projects with a total installed capacity of 213.4 MW, plus three small hydro projects totaling 15.5 MW. 
As in other Western states, impact on sage grouse populations is an issue in terms of siting wind projects. Montana's Sage Grouse Conservation Strategy, adopted in anticipation of Endangered Species Act listing decision by the U.S. Fish and Wildlife Service, could affect wind energy development in Montana. The strategy calls for wind energy development to be avoided in all sage grouse core areas.

Montana has 4.9 MW of distributed wind capacity installed, primarily consisting of turbines rated at $100 \mathrm{~kW}$ or less. Gordon Butte, the only community wind project, has an interconnection and power purchase agreement with NorthWestern Energy. Several other community wind projects are in the development phase; however, low power purchase agreement prices and lack of the 1603 Treasury program grant in lieu of tax credit have limited the financial viability of these projects. During the 2015 legislative session, several bills were proposed that would help open the market for distributed wind projects, including aggregate net metering, neighborhood net metering, and increasing the net metering cap; however, these bills did not move forward.

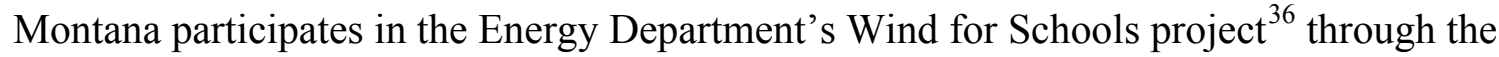
engagement of Montana State University, with 11 school systems installed in the state. The University of Montana also provides wind energy curricula.

Note that Eastern Montana is also supported by the Midwest Regional Resource Center.

\subsubsection{Oregon}

As of the end of 2015, Oregon has a total installed capacity of 3,153 MW (WINDExchange 2016). Despite this incredible progress, new project development has stalled due to a number of factors including depressed demand for power, low natural gas prices, uncertainty about the persistence of federal policy, and utilities fulfilling their near-term RPS compliance targets. Because of this delay in construction activity, some projects that have already been approved through state and county processes need to either apply for permit extensions or let their existing permits expire. Twelve projects totaling 1,519 MW have approved permits, and another 1,628 MW of wind are in the permitting process, so the pipeline is primed for activity once the market turns around.

Inaccurate wind energy information also undermines long-term planning for new renewable resources in utility integrated resource planning. This is being addressed through active participation in the planning processes at the Oregon Public Utility Commission.

Transmission and market issues in the region further suppress wind development in the state. Improvements are needed in liquid bi-lateral markets for integration resources, a transition to 15minute scheduling, and development of a regional energy imbalance market. Regional advances are being made in certain areas, such as 15-minute scheduling and bilateral markets. Work on a regional energy imbalance market is more divided with many utilities and Bonneville Power Administration exploring a Northwest energy imbalance market option, while some larger

\footnotetext{
${ }^{36}$ http://apps2.eere.energy.gov/wind/windexchange/schools wfs project.asp
} 
utilities are considering joining CAISO $^{37}$ as an alternative. One positive development is that Senator Ron Wyden has become a strong supporter of a regional energy imbalance market.

As in other Western states, impact on sage grouse populations is an issue in terms of siting wind projects. Oregon is developing a state plan for sage grouse conservation that will affect the potential for wind energy development in the southeastern quadrant of the state. Oregon is attempting to avoid the core area exclusion approach used in other states by formulating a new regulatory approach and enhancing the compensatory mitigation system.

Oregon has 4.8 MW of distributed wind capacity installed, primarily located in territory covered by the Energy Trust of Oregon's incentive program. Oregon has a single 9-MW community wind project, PaTu Wind, which sells power through a power purchase agreement with Portland General Electric and a long-term transmission contract with Bonneville Power. Like other states in the region, additional distributed wind projects are limited by high installed costs and community wind projects are challenged by low power purchase agreement prices and lack of the investment tax credit cash grant.

Oregon also has one proposed offshore wind project, the 30-MW Principle Power WindFloat Pacific project, one of DOE's Offshore Wind Advanced Technology Demonstration Projects. Interest in offshore wind on the West Coast has been limited because the depth of the water is too great for typical offshore turbine installations. This demonstration project would use floating turbine platforms to address this issue. If successful, this approach could open up new areas for offshore development.

Columbia Gorge Community College was one of the original colleges offering wind technician training programs and continues to offer degree and certificate programs in renewable energy.

\subsubsection{Washington}

As of the end of 2015, Washington has a total installed capacity of 3,075 MW (WINDExchange 2016). Similar to other states in the Northwest, new project development has slowed due to factors such as depressed demand for power, low natural gas prices, uncertainty about the persistence of federal policy, and utilities fulfilling their near-term RPS compliance targets. Despite this dynamic, six projects totaling 1,307 MW have approved permits, and another 601 MW of wind are in the permitting process, so projects are ready to move forward once the market turns around.

Inaccurate wind energy information also undermines long-term planning for new renewable resources in utility integrated resource planning. This is being addressed through active participation in the planning processes at the Washington Utilities and Transportation Commission.

Transmission and market issues in the region further suppress wind development in the state. Improvements are needed in liquid bi-lateral markets for integration resources, a transition to 15minute scheduling, and development of a regional energy imbalance market. Regional advances are being made in certain areas, such as 15-minute scheduling and bi-lateral markets. Work on a regional energy imbalance market is more divided with many Washington public utilities and

\footnotetext{
${ }^{37}$ An independent, non-profit Independent System Operator (ISO) serving California
} 
Bonneville Power Administration exploring a Northwest energy imbalance market option, while Puget Sound Energy has signaled it would like to join the CAISO energy imbalance market as an alternative.

Washington has 12.7 MW of distributed wind capacity installed, of which 10.4 MW are also community wind projects (Coastal Energy Project and Swauk Wind). Washington State offers a production-based incentive of $\$ 0.12$ per kilowatt-hour for net-metered wind systems up to 100 $\mathrm{kW}$; however, the high installed cost of these systems remains a barrier. The incentive expires in June 2020, and efforts are underway to renew and expand this program.

\subsubsection{Wyoming}

By the end of 2015, Wyoming had 1,410 MW of installed wind capacity, representing total capital investment of $\$ 2.6$ billion across 21 projects. The wind industry in the state supplies more than $\$ 4$ million in annual land lease payments to farmers, ranchers, and other landowners potential (American Wind Energy Association 2015r). Wyoming has 5.8 MW of distributed wind capacity installed and no community wind projects.

As with other states in the region, transmission constraints limit development, although three large transmission projects have been proposed to deliver power to larger markets (American Wind Energy Association 2015r). Several large wind projects have been proposed for Wyoming to utilize that transmission capacity if the new lines move forward. Other siting considerations for wind development in Wyoming include a state tax on wind energy generated in the state and wildlife concerns relating to sage grouse and eagles. Wind education programs in Wyoming include programs at the University of Wyoming and Larimer County Community College, one of the original colleges offering certificate programs for wind turbine technicians.

Note that the Four Corners Wind Resource Center also supports activities in Wyoming. 


\section{Southeast Wind Energy Resource Center}

The Southeast Wind Energy Resource Center (SWERC) worked with NREL researchers to provide the following assessment of the state of the wind industry in this region.

The SWERC ${ }^{38}$ encompasses the following states: Alabama, Arkansas, Florida, Georgia, Kentucky, Louisiana, Mississippi, North Carolina, South Carolina, Tennessee, and Virginia. The $\mathrm{RRC}$ works to advance the wind industry in the Southeast by providing fact-based information to stakeholders, engaging electric utilities, engaging on wind energy permitting processes, and preserving access to quality wind resources, both onshore and offshore. The RRC is a joint effort of The Southeastern Wind Coalition and several partners, including the North Carolina Clean Energy Technology Center at North Carolina State University, Clemson University, Coastal Carolina University, Georgia Institute of Technology, the Florida Energy Systems Consortium, James Madison University, Navigant Consulting, and a network of more than 80 affiliate organizations. These partners have long been reliable sources of unbiased information on wind energy and have a long history of stakeholder engagement in the region.

The following section provides an overview of the wind industry in the region. It should be noted that improved technology and accessing the wind resource at higher above-ground heights allow for geographic expansion of wind development into areas such as the Southeast, which historically was categorized as having a poor wind resource and little potential for wind development (DOE 2015b). New potential wind capacity maps are available for a 2014 industry standard wind turbine installed on a 110-m tower, which represents plausible current technology options, and a wind turbine on a 140-m tower, which represents near-future technology options (WINDExchange 2015).

Table 15. Key Statistics for the Southeast Wind Energy Resource Center Region

\begin{tabular}{|c|c|c|c|c|c|c|c|c|c|c|c|}
\hline & $A L$ & $A R$ & FL & GA & KY & LA & MS & NC & SC & TN & VA \\
\hline $\begin{array}{l}\text { Installed Wind, } \\
2015(\mathrm{MW})^{39}\end{array}$ & .07 & .68 & .39 & .11 & .20 & .11 & .03 & .29 & .03 & 29 & .95 \\
\hline $\begin{array}{l}\text { Projected } \\
\text { Potential } \\
\text { Capacity (MW), } \\
80 \text { m, } 30 \% \text { CF }\end{array}$ & 118 & 9,200 & .4 & 130 & 61 & 410 & 0 & 808 & 185 & 309 & 1,793 \\
\hline $\begin{array}{l}\text { Projected } \\
\text { Potential } \\
\text { Capacity (MW), } \\
100 \text { m, 30\% CF }\end{array}$ & 568 & 49,962 & .4 & 294 & 699 & 2,840 & 0 & 1,500 & 1,215 & 817 & 3,466 \\
\hline $\begin{array}{l}\text { Contribution } \\
\text { from Distributed } \\
\text { Wind Projects, } \\
2014(\mathrm{MW})^{40}\end{array}$ & .1 & .7 & .39 & .11 & .20 & .11 & 0.03 & .29 & .03 & .14 & .95 \\
\hline $\begin{array}{l}\text { Proposed } \\
\text { Offshore Wind } \\
\text { Projects (MW) }\end{array}$ & & & & & & & & & & & $2,012^{41}$ \\
\hline
\end{tabular}

\footnotetext{
${ }^{38}$ http://www.sewind.org/

392015 Year End Wind Power Capacity Map. Available at http://apps2.eere.energy.gov/wind/windexchange/wind installed_capacity.asp

${ }^{40}$ Distributed wind project installed capacity is defined as 2003-2013 cumulative capacity (U.S. DOE 2015a).

${ }^{41}$ Virginia Offshore Wind Technology Advancement Project $12 \mathrm{MW}$, Dominion Virginia Power 2,000 MW
} 


\subsection{Renewable Portfolio Standards}

Of the states located in the SWERC's area, only North Carolina has an RPS. South Carolina and Virginia have goals, and the remaining eight states have neither in place.

Table 16. RPS Overview for Southeast Wind Resource Center States

\begin{tabular}{ll}
\hline & RPS \\
\hline AL & None \\
AR & None \\
FL & None \\
GA & None \\
KY & None \\
LA & None \\
MS & None \\
NC & $12.5 \% \times 2021$ (investor-owned utilities) \\
SC & $10 \% \times 2018$ (co-ops \& munis) \\
TN & Goal of $2 \%$ by 2021 \\
VA & None \\
\hline
\end{tabular}

\subsection{Workforce Development}

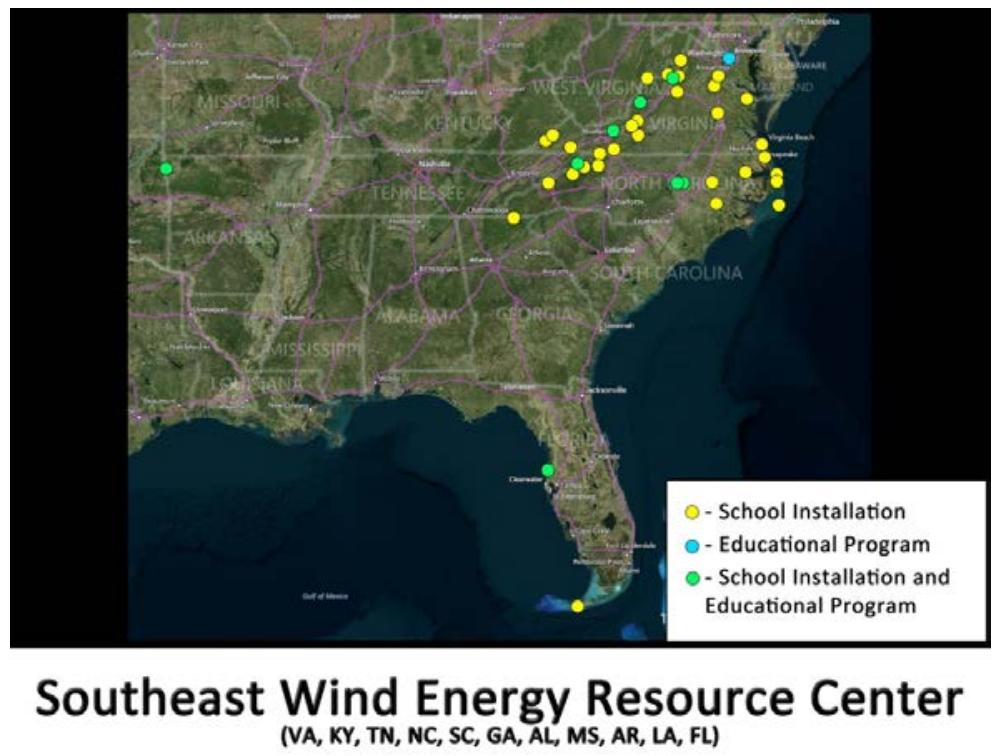

Figure 10. Map of school wind turbine projects, educational programs, and locations with both wind turbines and educational programs within the Southeast Wind Energy Resource Center's area

University-based wind energy programs in the Southeast are more limited than in other regions; however, robust programs at James Madison University, land-based wind programs at Virginia Technical University, offshore wind programs at Clemson University and Georgia Technical University, and distributed wind programs at Appalachian State University provide diversity. Educational activities are described in more detail in the state sections below. The WINDExchange website also offers information and interactive maps regarding workforce 
development, the DOE's Collegiate Wind Competition, the DOE's Wind for Schools project, school wind project locations, and locations of education and training programs in the SWERC region and other states. ${ }^{42}$

\subsection{Manufacturing}

NREL researchers compiled the following wind energy manufacturing data for this region as part of DOE's annual wind market report effort (DOE 2015c). Tier I represents major components such as blades and towers, and Tier II components are sub-components, such as inverters and electrical equipment, to make the Tier I equipment.

Table 17. Wind-Related Manufacturing Overview for Southeast Wind Energy Resource Center States

\begin{tabular}{lllll}
\hline Name & City & State & Component & Tier \\
\hline Molded Fiber Glass & Opp & AL & Enclosures & II \\
LM Wind Power & Little Rock & AR & Blades & I \\
GE Energy & Pensacola & FL & Turbine (nacelle assembly) & I \\
ZF Group & Gainesville & GA & Gearbox & I \\
Hailo LLC & Elberton & GA & Climbing devices & II \\
Blade Dynamics & New & LA & Blades & \\
& Orleans & & & Yaw, pitch control systems \\
Comer Industries & Charlotte & NC & II \\
ABB Inc. & Huntersville & NC & Electrical & II \\
IMO Group & Charleston & SC & Slew rings and drives & II \\
Ahlstrom Specialty & Bishopville & SC & Composites & II \\
Reinforcements & Union & SC & Bearings & II \\
Timken & Memphis & TN & Fasteners & II \\
Thomas and Betts & Chesterfield & VA & Slipring assembly \\
Corporation & County & & & \\
BGB Technology & & & & \\
\hline
\end{tabular}

\subsection{Key Stakeholder Groups and Deployment Challenges}

The SWERC targets these stakeholder groups:

- Utilities: Electric utilities are a critical stakeholder for all market sectors of wind energy, especially in the Southeast. The large, vertically integrated, regulated utilities are major economic drivers and have connections at the highest levels of state leadership. As a result, they have tremendous influence in energy policy and permitting, and that affects land-based, offshore, and distributed wind energy. SWERC engages utilities through its Utility Advisory Group, which provides a forum for the utilities to discuss wind energy issues in the Southeast.

- Federal and state decision makers: State policies have been the largest driver for renewable energy demand creation in the United States. So far in the Southeast, only North Carolina passed an RPS. However, the RRC sees broader interest from other states creating possible demand signals for wind energy. The RPS may not be the policy of choice in every state, but whatever the mechanisms end up being, it is likely that state policy makers will play a

\footnotetext{
${ }^{42}$ http://apps2.eere.energy.gov/wind/windexchange/schools/
} 
leading role in advancing or holding back wind deployment in the region. The value and need for unbiased, relevant, and actionable information provided to state policy makers will prove critical in helping to insure the appropriate development of the region's wind resources.

- Local decision makers: County commissioners, city managers, town managers, and other local leaders can have a tremendous influence on the ability to deploy wind energy in appropriately sited locations. They are often a "make or break" party for development projects. For example, a land-based project by Apex Wind in Alabama was effectively shut down by opposition from the county commission. This is a critical audience for delivering unbiased and fact-based information so that they are able to make informed decisions about wind energy projects and related policies in their jurisdiction.

- Industry: Wind industry developers, consultants, service, and supply chain companies are a powerful and historically underutilized ally in efforts to advance responsible wind energy deployment. As the voice of jobs and economic development, they have considerable influence with decision-makers and leaders. They are also a valuable source of technical information.

- Affiliate network: Many organizations are engaged in supporting wind energy efforts in the Southeast, from state energy offices to environmental organizations to academic groups. The SWERC will connect these diverse groups that are able to reach a wide range of stakeholders. The affiliate network is SWERC's "eyes, ears, and boots on the ground" to help identify issues that need to be considered and then to disseminate RRC information to address those issues. The affiliate network is open to any group with an interest in learning more about wind energy in the Southeast and is targeted toward those groups interested in engaging with SWERC's key stakeholders.

The information provided to these stakeholder groups addresses the following wind energy deployment market barriers that are prevalent in this region:

- Policy makers are not aware of the wind industry jobs and assets in their jurisdictions. This lack of information makes it difficult for them to support expanded wind development, especially in the face of vocal opposition to a project. SWERC activities include outreach to state and local decision makers to address this issue.

- Stakeholders in the region need credible, fact-based information to counter organized misinformation campaigns in the region.

- A lack of state RPS policies in the region (except for North Carolina) and low average electricity prices contribute to the lack of demand for wind energy and additional hurdles for wind deployment compared to some other regions.

- Navigating the potential conflicts with existing offshore activities is a challenge and requires significant engagement with many stakeholders. The SWERC is working to navigate these issues in North Carolina and South Carolina.

- The military is a very large economic driver in many states in the Southeast. Any conflicts with military operations - whether real, perceived, or just unknown — create uncertainty for development, especially in discussions between base commanders and local government officials. 
- Some level of utility support will be necessary for offshore wind to move forward in the Southeast. Because Southeast utilities are conservative by nature and they have no first-hand operating experience with offshore wind, the unknowns are often extrapolated to "worstcase" perceived risks. That includes all of the typical questions that are still unanswered for Southeast development, such as diurnal wind patterns, ramp rates, seasonality, demand coincidence, transmission needs, O\&M issues, etc.

\subsection{Collaborating Organizations}

Organizations that have collaborated with the SWERC include:

- ABB Inc.

- Alabama Rivers Alliance

- Alliance for Affordable Energy

- American Council on Renewable Energy

- American Planning Association

- American Wind Energy Association

- Apex Wind

- Arkansas Advanced Energy

- Arkansas Energy Office

- AWS Truepower

- AXYS Technologies

- Blue Green Alliance Foundation

- Cape Fear Community College

- Chesapeake Climate Action Network

- City of North Myrtle Beach

- City of Tybee Island

- Clean Line Energy

- Coastal Carolina University
- Consumer Energy Alliance

- COWI

- Distributed Wind Energy Association

- Dominion Power

- Duke Energy

- Duke University

- E4 Carolinas

- eFormative Options

- Electric Power Research Institute

- Energy Foundation

- Enterprise Florida

- Environment America

- Fishermen's Energy

- Florida Energy Systems Consortium

- Florida Sea Grant

- Georgia Department of Natural Resources, Coastal Resources Division

- Georgia Energy Center of Innovation 
- Georgia Energy Office

- Georgia Tech Strategic Energy Institute

- Green Law

- Gulf States Renewable Energy Association

- Iberdrola Renewables

- International Council for Local Energy Initiatives, Local Governments for Sustainability

- K\&L Gates

- Kentucky Energy Office

- Marsh

- Mississippi \& Alabama Sea Grant

- Mountain Association for Community Economic Development

- National Wildlife Federation

- Natural Resources Defense Council

- Navigant

- Nicholas Institute

- Normandeau Associates

- North Carolina Conservation Network

- North Carolina Energy Office

- North Carolina Ports Authority

- North Carolina Sea Grant

- North Carolina Sustainable Energy Association
- North Myrtle Beach Chamber of Commerce

- Nucor Corporation

- Ocean Isle Fishing Center

- Parker Poe

- REAP

- Research Triangle Cleantech Cluster

- Saertex

- Santee Cooper

- Savannah River National Laboratory

- SCANA Corporation

- ScottMadden

- Siemens

- Sierra Club

- Signal Energy

- South Carolina Clean Energy Business Alliance

- South Carolina Coastal Conservation League

- South Carolina Sea Grant

- South Carolina State Ports Authority

- Southeast Energy Efficiency Alliance

- Southern Company

- Tennessee Energy Office

- Tetra Tech 
- U.S. Offshore Wind Collaborative

- University of North Carolina Chapel Hill

- University of North Carolina Charlotte (EPIC Center)
- Virginia Conservation Network

- Virginia Offshore Wind Coalition

- Wake Forest University.

\subsection{State Updates}

\subsubsection{Alabama}

Although Alabama has no utility-scale wind installed, the state is home to 16 companies and 18 facilities that are involved in the full value chain of the wind energy industry (including headquarters), according to AWEA. Alabama Power has contracts in place to purchase $404 \mathrm{MW}$ of wind energy from projects located in Kansas and Oklahoma. These contracts, put in place in 2011 and 2012, can provide power for up to 100,000 homes.

\subsubsection{Arkansas}

Arkansas does not have wind development, but it is home to 12 wind manufacturing facilities, according to AWEA, and the Arkansas Electric Cooperative Corporation has three power purchase agreements for wind energy totaling 309 MW from projects in Oklahoma and Kansas. All three agreements have been signed over the past few years: a 2012 agreement to purchase 51 MW from the Flat Ridge 2 South Wind Farm in Kansas, a 2013 agreement to purchase 150 MW from the Origin Wind Farm in Oklahoma, and a 2015 agreement to purchase 108 MW from the Drift Sand Wind Farm in Oklahoma.

\subsubsection{Florida}

Although no wind projects have been installed in the state, Gulf Power signed a power purchase agreement to bring wind power into Florida from Oklahoma's Kingfisher Wind Project. The Florida Public Service Commission approved the power purchase agreement for $178 \mathrm{MW}$ in May 2015. Resource assessment and early development work for several sites in northern Florida have been undertaken, but there are no projects under development.

Florida is the headquarters to several major players in the wind energy industry, with 50 facilities involved in the full value chain of the wind energy industry. NextEra Energy Resources, headquartered in Juno Beach, is the largest owner of wind power capacity in the United States, and Siemens, a major wind turbine manufacturer, is headquartered in Orlando. Florida has been successful in attracting manufacturing investment for the wind industry. Market leader General Electric has a wind turbine assembly facility in Pensacola, several other wind energy manufacturers have Florida facilities, and Siemens Energy opened a Wind Service Training Center in Orlando in September 2013. 


\subsubsection{Georgia}

Georgia Power signed a power purchase agreement to bring $250 \mathrm{MW}$ of wind energy into its service territory from Oklahoma wind projects starting in 2016. Additionally, Southern Company submitted an application to BOEM for an interim policy lease that would allow for meteorological measurement activities offshore from Tybee Island.

Georgia is home to more than 32 companies and nearly 50 facilities that are involved in the full value chain of the wind energy industry. The Georgia Wind Working Group continues to advance the wind industry in the state by creating educational opportunities for all stakeholders. Close coordination with the Georgia Public Service Commission resulted in several opportunities for commissioners to speak in support of wind energy activities within the state. The second annual Georgia Tech Energy Expo in April 2015 brought together state and national energy experts for a comprehensive and interactive event with an enthusiastic public audience. The Georgia Wind Working Group utilized its network of professional affiliates to populate the discussion panels for this event. Georgia Public Service Commissioner Chuck Eaton broached the importance of energy diversity and employing a long-term outlook when planning the energy utility future of the state, while Commissioner Tim Echols moderated a panel on the infrastructure and workforce of state energy development while advocating the importance of renewables.

\subsubsection{Kentucky}

Kentucky is already home to 15 companies and 16 facilities (according to AWEA) that are involved in the full value chain of the wind energy industry, even though no wind farms exist in the state. Some notable examples include companies like Rotek and Muehlhan Wind Power.

Recently, turbine manufacturers have designed taller towers and longer blades, improving energy output, especially at lower-wind-speed sites. In Kentucky, the wind potential with future turbine technology is estimated to be more than 524.5 terrawatt-hours per year.

\subsubsection{Louisiana}

Louisiana has nine companies and 10 facilities that are involved in the full value chain of the wind energy industry, even though no wind farms exist in the state. Blade Dynamics manufactures wind turbine blades at their facility in New Orleans. The AEP Southwestern Electric Power Company has power purchase agreements for $469 \mathrm{MW}$ of wind energy. These contracts bring wind from several projects in Texas, Oklahoma, and Kansas.

\subsubsection{Mississippi}

According to AWEA, Mississippi is home to seven companies and eight facilities that are involved in the full value chain of the wind energy industry. Though the state has no utility-scale wind installed, the potential areas for wind development in the state are increasing due to technological advancements for taller turbines and longer blades.

\subsubsection{North Carolina}

North Carolina will be home to the first large utility-scale wind farm in the Southeast. The Amazon Wind Farm U.S. East project by Iberdrola Renewables will include an initial phase of 208 MW of wind energy in Pasquotank County and Perquimans County in the northeastern part of the state. During the project's groundbreaking ceremony in July, North Carolina Governor Pat 
McCrory expressed support for the project's economic development benefits. The turbines will be located on private land leased by Iberdrola and will result in millions in tax and landowner revenue over the 20 - to 30 -year lifetime of the project.

The jobs and economic development generated by this project will build on the wind industry jobs already present in the state through the supply chain. There are more than 25 facilities in North Carolina that supply component parts for the wind industry, according to AWEA, and building wind projects in the state can help to strengthen and build the local supply chain. The Amazon project will provide an opportunity for communities in the Southeast to see first-hand the benefits of utility-scale wind. Coastal North Carolina has several kilowatts of distributed wind, some of which are Wind for Schools project turbines.

Despite these advancements, barriers to developing wind in North Carolina remain. The state has a weak RPS of $12.5 \%$ by 2021 , and opponents have organized misinformation campaigns. In April 2015, the North Carolina Clean Energy Technology Center at North Carolina State University, as a part of SWERC, published fact sheets ${ }^{43}$ to address some of the key wind energy myths being spread regarding health impacts, economic impacts, environmental/wildlife impacts, and grid/military impacts.

North Carolina is also participating in the Wind for Schools project, through the engagement of Appalachian State University, with the installation of 11 school systems within the state.

\subsubsection{South Carolina}

South Carolina has a few kilowatts of wind power capacity installed as a result of Wind for Schools projects deployed in North Carolina, as well as ongoing efforts for offshore wind in the state. The state's BOEM task force is refining the areas offshore from Horry County and Georgetown County that will be included in a Call for Information and potentially offered for lease. In 2014, the South Carolina General Assembly passed a resolution in support of wind energy in the state. The resolution acknowledges the state's wind manufacturing assets, offshore wind resource potential, supportive local governments and Clemson University's large-scale wind turbine drivetrain testing facility in Charleston. Several local governments in the state (Charleston, North Charleston, and North Myrtle Beach) have also expressed support for wind energy.

Coastal Carolina University hosted a wind energy forum in late 2014 to engage industry experts, academics, and state and local leaders in a discussion about advancing offshore wind energy opportunities in South Carolina and the Southeast. The event included remarks from a number of state and local leaders, with Senator Greg Hembree outlining a bill that he introduced in 2015 to enable the investor-owned utilities in the state to recover the costs of a small-scale demonstration project through their rates.

Clemson University's South Carolina Electric \& Gas Energy Innovation Center ${ }^{44}$ is a wind turbine drivetrain testing and grid simulator facility that completed construction in 2013. Testing performed at the Center benefits the industry as a whole while also drawing attention to the Southeast. In addition to technical testing, the facility provides tours, offers education on the

\footnotetext{
${ }^{43}$ Available at http://nccleantech.ncsu.edu/technology/renewable-energy/wind-energy/

${ }^{44}$ http://clemsonenergy.com/
} 
technical characteristics of wind turbines, and creates opportunities for stakeholders to meet and learn.

\subsubsection{Tennessee}

Tennessee is home to the Southeast's only utility-scale wind farm, the 29-MW Buffalo Mountain project completed in 2004. According to AWEA, the state also has 27 companies and more than 30 facilities that are involved in the full value chain of the wind energy industry. The Tennessee Valley Authority has contracts for more than 1,500 MW of wind energy from Kansas, Illinois, and Iowa (American Wind Energy Association 2015m). The Eastern Clean Line transmission line is a proposed project that could facilitate the import of additional wind energy from the Oklahoma Panhandle region (Monies 2015b).

\subsubsection{Virginia}

The state's proposed land-based wind projects are making progress in the planning stages and the state has expanded net metering, but much of the focus remains on solar energy. Virginia's offshore wind activities are moving forward with progress in the BOEM leasing process.

Virginia Electric and Power Company was awarded a lease for the Virginia Wind Energy Area, and Virginia's Department of Mines Minerals and Energy was awarded a research lease for the two-turbine Virginia Offshore Wind Technology Advancement Project. This project, led by Dominion Virginia Power, is one of DOE's Offshore Wind Advanced Technology Demonstration Project and will deploy two direct-drive Alstom wind turbines 26 miles off the coast of Virginia Beach. The project, designed to reduce costs and uncertainty for a future largescale project, is undertaking a stakeholder process to find a path forward for the project after initial cost estimates exceeded the conceptual estimate.

In addition, the Virginia Offshore Wind Coalition is an industry group comprised of developers, supply chain companies, localities, and utilities. The group's objectives are to develop Hampton Roads as a logistical hub of the offshore wind supply chain, to promote industry and employment opportunities in the commonwealth, and to cultivate wind projects off the Virginia shore (Virginia Offshore Wind Coalition 2014).

Installation of small wind projects has slowed. ${ }^{45}$ Some small wind projects are installed as part of the Wind for Schools project ${ }^{46}$ through the engagement of James Madison University, with nine school systems installed in the state. James Madison University also participated in the 2014 Collegiate Wind Competition. Virginia Technical University has also been active in wind energy programs, including hosting of the 2015 North American Wind Energy Academy symposium. ${ }^{47}$

\footnotetext{
${ }^{45}$ James Madison University offers a time-lapse illustrating small wind energy system installations in Virginia from 2000 to 2015: http://ecodefend.t15.org/

${ }^{46} \mathrm{http}: / /$ apps2.eere.energy.gov/wind/windexchange/schools wfs project.asp

${ }^{47}$ http://www.nawea.org/
} 


\section{Updates for States Outside of RRC Regions}

The WINDExchange team based at NREL researched the current state of wind energy in states outside of RRCs and compiled the following brief summaries. The states not included as part of an RRC are California, Delaware, Kansas, Maryland, Nebraska, Oklahoma, Texas, and West Virginia.

Note that Delaware, Nebraska, and West Virginia do not have any manufacturing facilities serving the wind industry.

\subsection{California}

As of the end of 2015, California's installed wind capacity was 6,108 MW (WINDExchange 2016). A vast majority of this clean generation comes from the 124 wind projects installed across the state. This amount of development equates to an $\$ 11.7$ billion capital investment and provides approximately $\$ 17.8$ million in annual land lease payments (American Wind Energy Association 2015b). California generated 12,998 gigawatt-hours from wind in 2014, equivalent to approximately $6.57 \%$ of the state's gross system power (California Energy Commission 2016). The state saw $107 \mathrm{MW}$ of wind energy come online through the third quarter of 2015 (American Wind Energy Association 2015n).

Although the state adopted a $20 \%$ by 2020 RPS in 2002 that was increased to $33 \%$ in 2011 , Governor Jerry Brown proposed a new goal of 50\% renewable energy by 2030 in early 2015 (Siders 2015). The state has been working to build the necessary transmission to achieve its targets. Two transmission projects will play an integral role in the state meeting its RPS goal. The nearly \$1.9 billion Sunrise Powerlink Project, a 117-mile transmission project that came online in 2012, has allowed San Diego Gas and Electric to increase the amount of clean generation it can provide its customers (San Diego Gas \& Electric 2012). The \$2.1 billion Tehachapi Renewable Transmission Project (Edison International) is a 173-mile project that is expected to be fully completed by late 2016 and have the ability to transmit 4,500 MW of wind energy to the state (Southern California Edison 2014).

Siting challenges in California include impacts to wildlife (particularly raptors), desert tortoises, and other species. The state is developing its Desert Renewable Energy Conservation Plan to help address this issue, but the impact of this plan on wind energy's ability to move forward in the state has raised concerns regarding future development (Roth 2014).

Although the state has a strong potential for offshore wind, there are many challenges to overcome prior to any project development. These include establishing a more streamlined regulatory process, working with BOEM to establish an offshore wind task force, and establishing an environmental baseline for potential project locations to understand impacts on avian and marine wildlife. The high cost of offshore wind compared to onshore wind and solar has also been a challenge. It should be noted that California's deep waters will require floating platforms for offshore wind projects, and these platforms are still in the prototype stage (van Dam 2014).

California ranks third among the top five states for wind energy generation (the other top five states are Texas, Iowa, Oklahoma, and Kansas). California is home to more than 2,000 jobs 
related to the wind energy industry (American Wind Energy Association 2015b), and it ranked among the top three states in 2014 in terms of adding distributed wind capacity (U.S. Department of Energy 2015a).

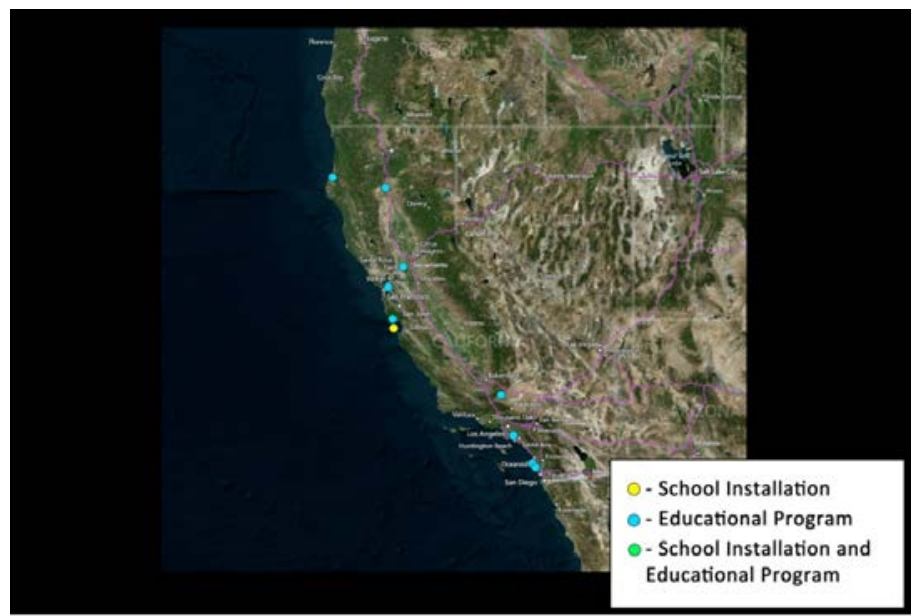

California

Figure 11. Map of school wind turbine projects, educational programs, and locations with both wind turbines and educational programs in California

Two California schools have participated in the DOE Collegiate Wind Competition, with the California Maritime Academy participating in the 2014 Collegiate Wind Competition and as an entrant in the 2016 Competition. California State University Chico is also an entrant for the 2016 Competition. Several universities in the state (such as the University of California, Davis and University of California, Berkeley) have been at the forefront of wind energy research. Visit the WINDExchange website for information about school wind projects and educational programs in California and other states. ${ }^{48}$

NREL researchers compiled the following California wind energy manufacturing data as part of DOE's annual wind market report effort (DOE 2015c). Tier I represents major components such as blades and towers, and Tier II components are sub-components, such as inverters and electrical equipment, to make the Tier I equipment.

Table 18. California Wind-Related Manufacturing Overview

\begin{tabular}{lllll}
\hline Name & City & State & Component & Tier \\
\hline PowerWorks & Tracy & CA & Distributed wind & I \\
Molded Fiber Glass & Adelanto & CA & Nacelle components & II \\
Halus Power Systems & $\begin{array}{l}\text { San } \\
\text { Leandro }\end{array}$ & CA & Turbine Refurbishing & I \\
\hline
\end{tabular}

${ }^{48}$ http://apps2.eere.energy.gov/wind/windexchange/schools/ 


\subsection{Delaware}

Delaware has 2 MW of wind capacity installed (at the University of Delaware's Lewes campus), with no wind projects under construction and no manufacturing facilities in the state supporting the wind industry. Delaware has implemented an aggressive RPS that requires all retail electricity suppliers to purchase $25 \%$ of the electricity sold in the state from renewable sources by the end of the 2026 state fiscal year. However, the RPS requirements leading to wind energy projects are effectively reduced by a determination that provides a two times REC multiplier for the energy output of certain natural gas powered fuel cells (State of Delaware Public Service Commission 2011).

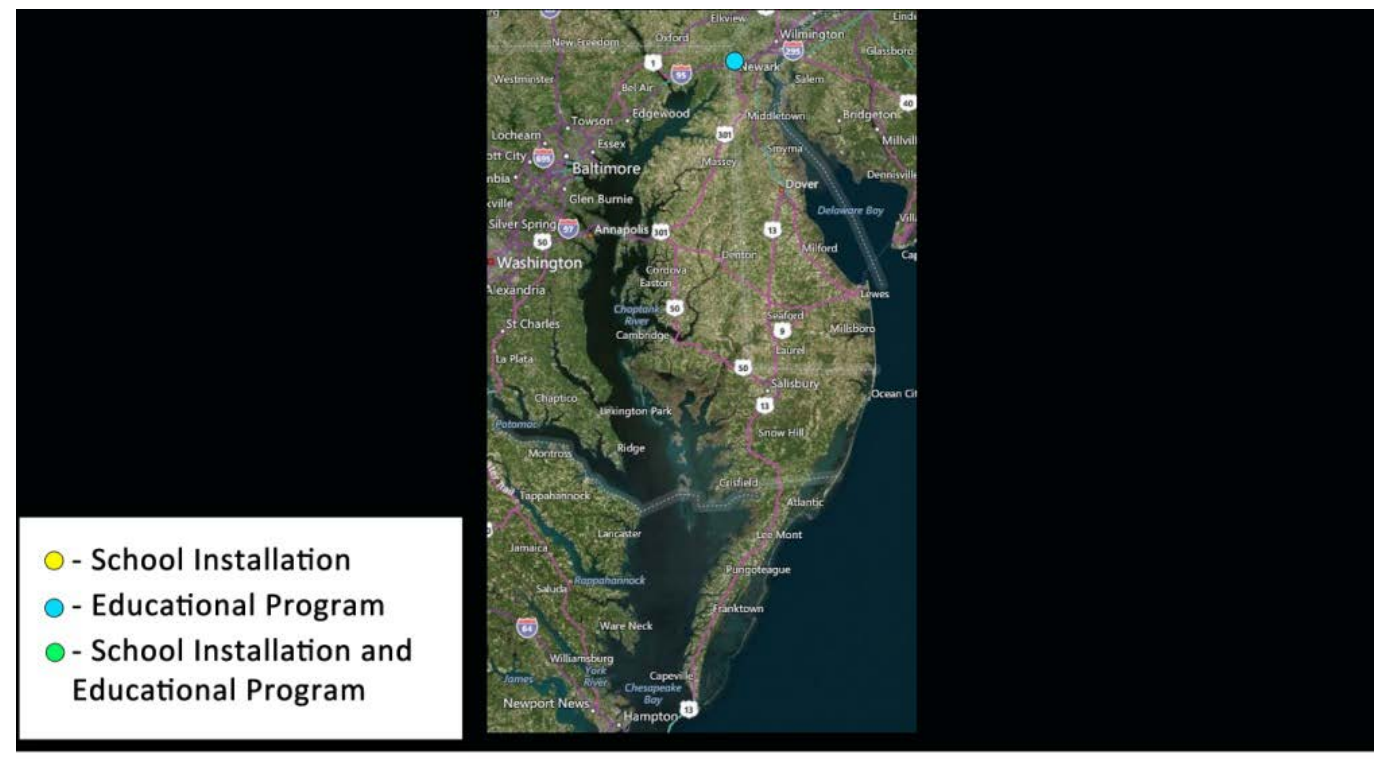

\section{Delaware}

Figure 12. Map of sole educational program location in Delaware

The University of Delaware has developed extensive capabilities in offshore wind technology and research involving the social acceptance of land-based and offshore wind technologies. Visit the WINDExchange website for information about school wind projects and educational programs in Delaware and other states. ${ }^{49}$

\subsection{Kansas}

At the end of 2015, Kansas had 3,766 MW of installed wind capacity (WINDExchange 2016). A vast majority of this clean generation comes from the 30 wind projects that have been installed across the state. This amount of development equates to a $\$ 5.5$ billion capital investment and provides approximately $\$ 8.9$ million in annual land lease payments. Wind energy provides further economic development in the state through wind turbine manufacturing. Siemens operates a $\$ 50$ million nacelle assembly facility in Hutchinson (American Wind Energy Association 2015d). Kansas generated 10,844 gigawatt-hours from wind in 2014 (American Wind Energy Association 2015m).

\footnotetext{
${ }^{49} \mathrm{http}: / /$ apps2.eere.energy.gov/wind/windexchange/schools/
} 
The state enacted an RPS in May 2009 that requires certain utilities to generate or purchase 20\% of their electricity from renewable resources by 2020 (American Wind Energy Association 2015d). The RPS was repealed in May 2015 and was replaced with a voluntary goal of $20 \%$ electricity from renewable resources by 2020 .

Several barriers inhibit wind development in Kansas. According to a survey conducted by Kansas State University in 2010, environmental concerns rated the highest. People are very concerned about potential development in the Flint Hills; the proximity of wind turbines to the great wetlands of Cheyenne Bottoms and Quivera Wildlife Refuge, an extremely popular stopover point for waterfowl and cranes; and the impact on prairie chicken species that are under threat in Kansas. Other concerns about developing wind power in Kansas include health impacts and property rights. An additional barrier to wind development in the state is a lack of transmission from the wind-rich western part of the state to load centers in the eastern part of the state (National Renewable Energy Laboratory 2013).

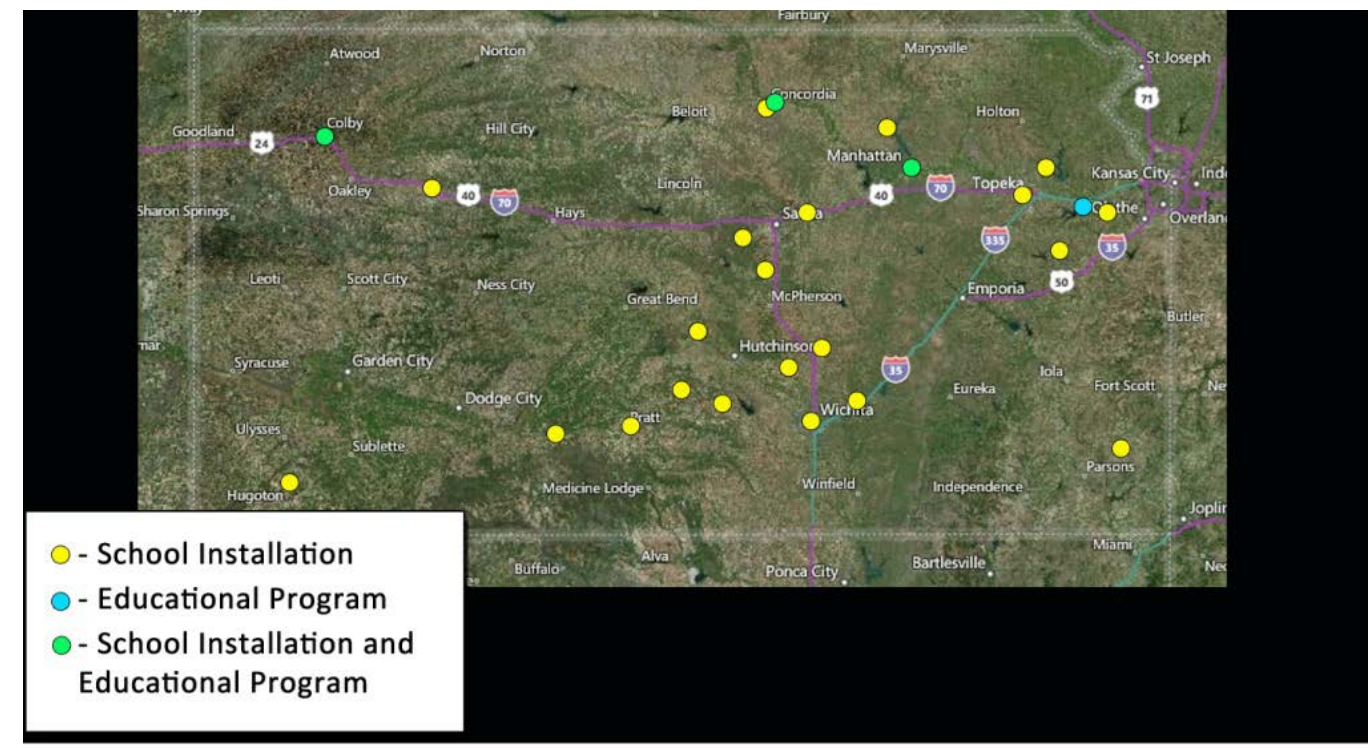

\section{Kansas}

Figure 13. Map of school wind turbine projects, educational programs, and locations with both wind turbines and educational programs in Kansas

Kansas participates in the Wind for Schools project through the engagement of Kansas State University, with 28 school systems installed. According to state facilitator Ruth Douglas Miller, 24 of the 28 turbines are operational, and the state's Wind Application Center is working to get these systems collecting data and sending information to the OpenEI turbine database. ${ }^{50}$ The disabled turbines must be repaired, dismantled and removed, or moved to other schools. A tight budget situation due to state-level policy makes it difficult for schools to maintain turbines; nevertheless, the Wind Application Center still receives occasional requests for assistance in installing a new turbine.

${ }^{50}$ http://en.openei.org/wiki/Wind for Schools Portal 
Kansas State University also participated in the 2014 Collegiate Wind Competition and is an entrant for the 2016 Competition. The University of Kansas also participated in the 2014 Collegiate Wind Competition. Visit the WINDExchange website for information about school wind projects and educational programs in Kansas and other states. ${ }^{51}$

NREL researchers compiled the following Kansas wind energy manufacturing data as part of DOE's annual wind market report effort (DOE 2015c). Tier I represents major components such as blades and towers, and Tier II components are sub-components, such as inverters and electrical equipment, to make the Tier I equipment.

Table 19. Kansas Wind-Related Manufacturing Overview

\begin{tabular}{lllll}
\hline Name & City & State & Component & Tier \\
\hline Jupiter Group & Junction & KS & Nacelle covers and spinners & II \\
Craka & City & & Electrical & II \\
Siemens & Hutchinson & KS & Turbines & I \\
\hline
\end{tabular}

\subsection{Maryland}

Maryland has $190 \mathrm{MW}$ of installed wind capacity at the end of 2015 (WINDExchange 2016). With an RPS of $20 \%$ by 2022 , Maryland has many additional opportunities for land-based and offshore projects, although most of the attention is focused on offshore wind. BOEM, under the U.S. Department of the Interior, has granted a competitive lease for sites in Maryland (U.S. Department of Energy 2015c). Nearly 80,000 acres of offshore federal waters were auctioned off in August 2014 with U.S. Wind Inc. attaining the rights. Preliminary project planning is underway, and a site assessment plan will be submitted to BOEM (Wheeler 2015a). Onshore development has recently been hampered due to concerns related to potential radar, wildlife, aesthetic, and property value impacts (Wheeler 2015b).

\footnotetext{
${ }^{51}$ http://apps2.eere.energy.gov/wind/windexchange/schools/
} 


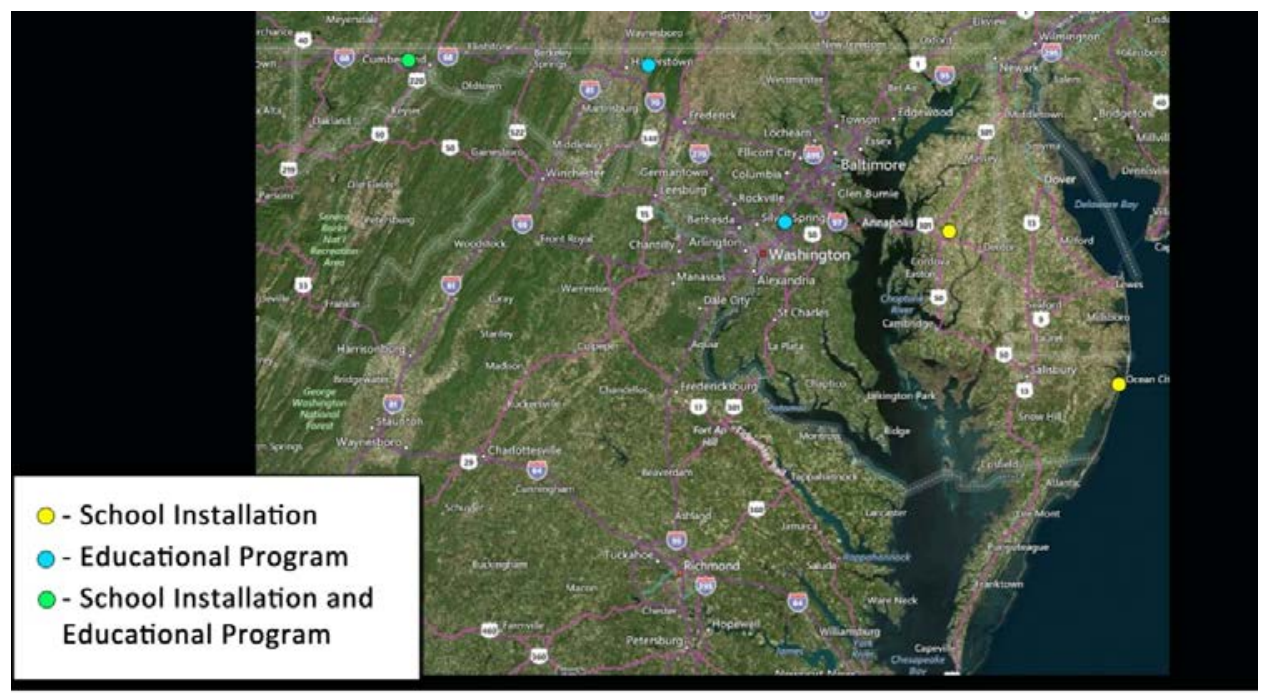

\section{Maryland}

Figure 14. Map of school wind turbine projects, educational programs, and locations with both wind turbines and educational programs in Maryland

Although Maryland does not have many wind energy educational programs, the University of Maryland is an entrant for the 2016 Collegiate Wind Competition. Visit the WINDExchange website for information about school wind projects and educational programs in Maryland and other states. $^{52}$

NREL researchers compiled the following Maryland wind energy manufacturing data as part of DOE's annual wind market report effort (DOE 2015c). Tier I represents major components such as blades and towers, and Tier II components are sub-components, such as inverters and electrical equipment, to make the Tier I equipment.

Table 20. Maryland Wind-Related Manufacturing Overview

\begin{tabular}{lllll}
\hline Name & City & State & Component & Tier \\
\hline LAl International & Westminster & MD & Bearing cages & II \\
\hline
\end{tabular}

\subsection{Nebraska}

Nebraska had 890 MW of installed wind capacity at the end of 2015 (WINDExchange 2016). A vast majority of this clean generation comes from the 16 wind projects that have been installed across the state. This amount of development equates to a $\$ 1.5$ billion capital investment and provides approximately $\$ 2.4$ million in annual land lease payments (American Wind Energy Association 2015f). The state has four projects with signed power purchase agreements under construction totaling more than $500 \mathrm{MW}$ (Nebraska Energy Office 2016). When the last of these installations come online at the end of 2016, the state will have 1,325 MW in operation.

${ }^{52}$ http://apps2.eere.energy.gov/wind/windexchange/schools/ 
Lincoln Electric System has committed to adding two wind projects, one of which will be located in-state, totaling $173 \mathrm{MW}$ along with one 5-MW solar project. These developments are expected to save Lincoln Electric System customers more than \$420 million over the next 25 years (Laukaitis 2014).

Additional commitments by local utilities are beginning to shape Nebraska's energy future. Nebraska Public Power District is working to achieve its goal of $10 \%$ energy from renewable resources by 2020. In 2015, it announced the final route for its $\$ 361$ million R-Project. The 220plus-mile project will provide new transmission capacity to address future renewable generation (Nebraska Public Power District 2015). 2015 also saw the Omaha Public Power District board approve work to support the Midwest Transmission Project, a 180-mile transmission line that will run from Nebraska City to Sibley, Missouri. Scheduled to be in service by late 2016, the project will help advance renewable energy and increase system reliability (Omaha Public Power District 2015a). The Omaha Public Power District also confirmed its plan to have more than 30\% of future retail generation provided by renewable resources (Omaha Public Power District 2015b).

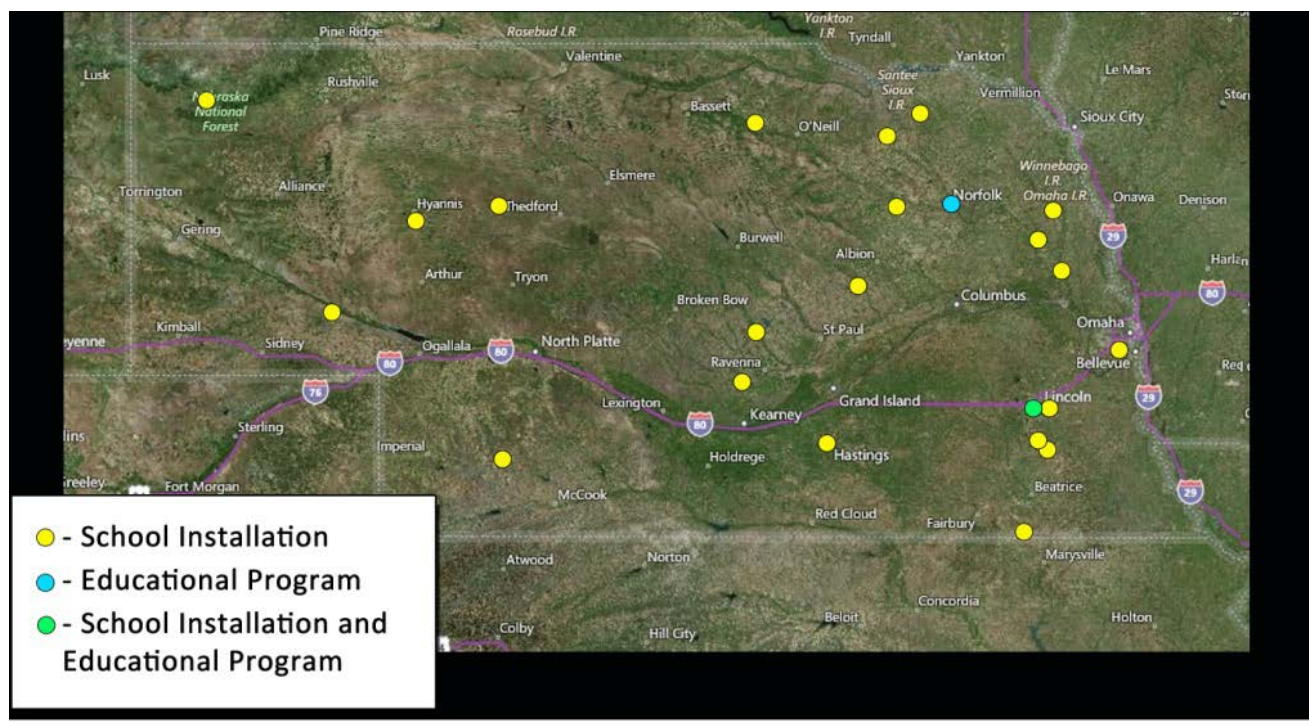

\section{Nebraska}

Figure 15. Map of school wind turbine projects, educational programs, and locations with both wind turbines and educational programs in Nebraska

The Nebraska Farmers Union and the American Corn Growers Foundation Wealth from the Wind program have performed a lot of public outreach to communities and found that customers and landowners are very supportive of wind energy. In addition, since 2008, volunteers from farmer and rancher organizations, state agencies, public power utilities, and higher education institutions have organized the annual Nebraska Wind and Solar Conference and Exhibition to advance these industries in the state. ${ }^{53}$

\footnotetext{
${ }^{53}$ http://nebraskawindandsolarconference.com/
} 
Nebraska does not have an RPS or a renewable energy goal. A 2015 proposal to stimulate wind energy in the state was filibustered and removed from the 2015 legislative agenda (Walton 2015). Given the level of wind energy support from many of Nebraska's state senators, new legislation to facilitate wind development is anticipated in the 2016 legislative session (personal communication, Dan McGuire).

Nebraska participated in the original Wind for Schools project through the engagement of the University of Nebraska-Lincoln, with the installation of $25 \mathrm{~K}-12$ partner school systems in the state. The University of Nebraska Wind Applications Center is actively working with those partner schools to enhance their curriculum, career development, and the overall operation of their existing small-scale wind turbines in 2016. Visit the WINDExchange website for information about school wind projects and educational programs in Nebraska and other states. ${ }^{54}$

Nebraska has no wind-related manufacturing.

\subsection{Oklahoma}

By the end of 2015, Oklahoma had installed a wind capacity of 5,184 MW (WINDExchange 2016). A vast majority of this clean generation comes from the 34 wind projects that have been installed across the state. This amount of development equates to a $\$ 7$ billion capital investment and provides approximately $\$ 11.4$ million in annual land lease payments (American Wind Energy Association 2015j). In 2010, Oklahoma set a renewable energy target for $15 \%$ of total installed generation capacity for operating electric utilities to be renewable sources by 2015 (American Wind Energy Association 2015j).

Barriers to wind development in the state include legislation for decommissioning requirements (Justia 2010), siting requirements (setbacks from schools, hospitals, and airports), as well as notification requirements (Monies 2015a). In May 2015, Oklahoma's Governor Mary Fallin signed Senate Bill 498, which is designed to end property tax exemptions for new wind developments in 2017 (Green 2015).

Oklahoma wind energy developments export clean energy to multiple states, including Alabama, Nebraska, Arkansas, and Colorado (Teague 2015). Oklahoma also is home to a national example of the private sector working with wind projects, an Oklahoma wind project that provides power to a Google data center located in the northeastern part of the state (Google 2012).

Visit the WINDExchange website for information about school wind projects and educational programs in Oklahoma and other states. ${ }^{55}$

\footnotetext{
${ }^{54} \mathrm{http}: / /$ apps2.eere.energy.gov/wind/windexchange/schools/

${ }_{55}$ http://apps2.eere.energy.gov/wind/windexchange/schools/
} 


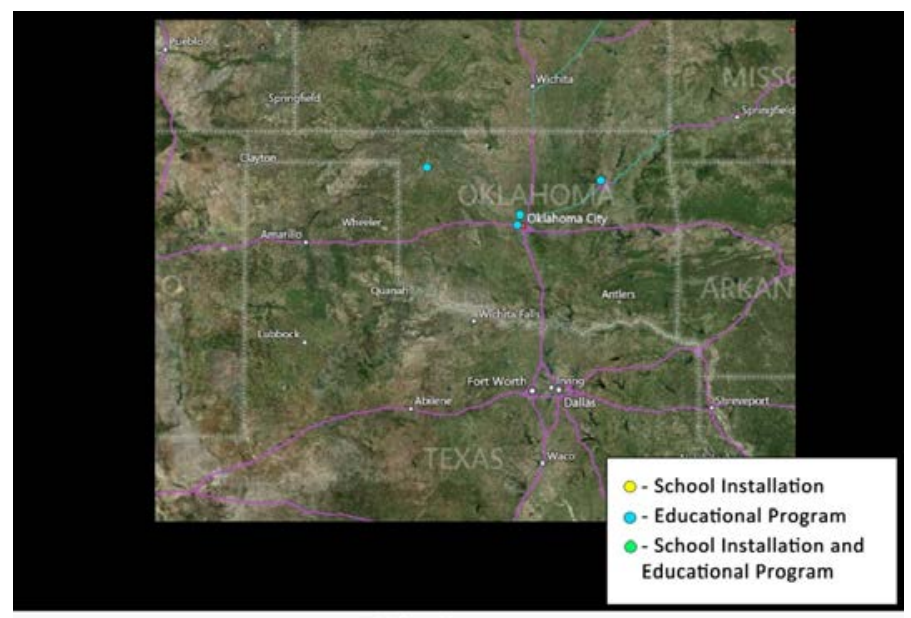

Oklahoma

Figure 16. Map of school wind educational programs in Oklahoma

NREL researchers compiled the following Oklahoma wind energy manufacturing data as part of DOE's annual wind market report effort (DOE 2015c). Tier I represents major components such as blades and towers.

Table 21. Oklahoma Wind-Related Manufacturing Overview

\begin{tabular}{lllll}
\hline Name & City & State & Component & Tier \\
\hline Bergey Windpwer & Norman & OK & Distributed Turbines & I \\
Trinity Structural Towers & Tulsa & OK & Towers & I \\
\hline
\end{tabular}

\subsection{Texas}

By the end of 2015, Texas had an installed wind capacity of 17,713 MW, more than any other state in the nation (WINDExchange 2016). Texas established an RPS in 1999 and amended it in 2005. The current RPS requires 5,880 MW of renewable energy by 2015 . The state also has a target of 10,000 MW of renewable capacity by 2025 (which the wind energy industry met in 2010) (American Wind Energy Association 20151). New transmission has helped spur recent wind development in the state. Completed in late 2013, the Competitive Renewable Energy Zone transmission lines have helped increase wind energy in the state while lowering curtailment for already established projects. The 1,811 MW of new capacity installed in 2014 is said to be directly tied to this transmission expansion (American Wind Energy Association 2015m).

New Mexico, Texas, and California led the United States in new distributed wind power capacity additions in 2014 across all turbine sizes (U.S. Department of Energy 2015a).

Some cities in Texas have their own renewable energy goals that stretch beyond the state RPS. For example, Georgetown, Texas announced that its municipal utility, Georgetown Utility Systems, could soon get 100\% of its electricity from renewable (Gross 2015). 
In 2015, Texas produced more wind power in a given amount of time than ever in history. The state reached "peak wind" at 8:48 p.m. on March 26, when the state's wind farms produced $10,296 \mathrm{MW}$ of electricity, or $29 \%$ of the total electricity load of the state's main power grid (Magill 2014).

Texas has several educational programs that focus on wind energy: Texas Tech University; the University of Houston; and Texas State Technical College, West Texas. Visit the WINDExchange website for information about school wind projects and educational programs in Texas and other states. ${ }^{56}$

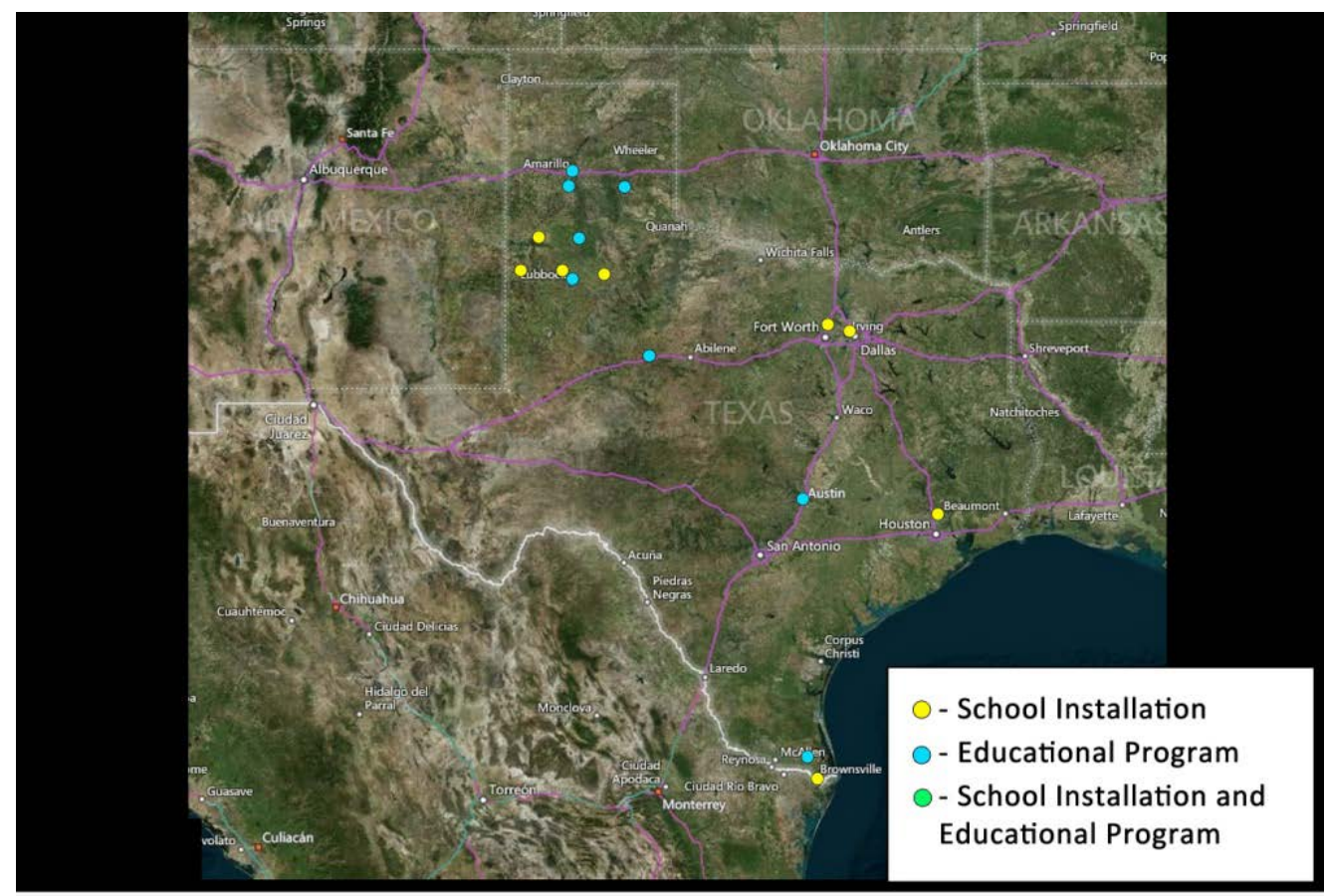

Texas

Figure 17. Map of school wind turbine projects, educational programs, and locations with both wind turbines and educational programs in Texas

NREL researchers compiled the following Texas wind energy manufacturing data as part of DOE's annual wind market report effort (DOE 2015c). Tier I represents major components such as blades and towers, and Tier II components are sub-components, such as inverters and electrical equipment, to make the Tier I equipment.

${ }^{56}$ http://apps2.eere.energy.gov/wind/windexchange/schools/ 
Table 22. Texas Wind-Related Manufacturing Overview

\begin{tabular}{lllll}
\hline Name & City & State & Component & Tier \\
\hline Molded Fiber Glass & Gainesville & TX & Blades & I \\
CB Gear and Machine & Houston & TX & Gears & II \\
CAB Inc. & Nacogdoches & TX & Flanges & II \\
Diab Inc. & Desoto & TX & Blade cores & II \\
Barr Fabrication & Brownwood & TX & Tower internals & II \\
All-Pro Fasteners & Arlington & TX & Bolts & II \\
RBC Bearings & Houston & TX & Bearings & II \\
EMA Electromecanica & Sweetwater & TX & Electronics & II \\
Broadwind & Abilene & TX & Towers & I \\
Alstom Power & Amarillo & TX & Turbines & I \\
\hline
\end{tabular}

\subsection{West Virginia}

At the end of 2015, West Virginia had $583 \mathrm{MW}$ of installed wind capacity (WINDExchange 2016). A vast majority of this clean generation comes from five wind projects that have been installed across the state. This amount of development equates to a $\$ 1.2$ billion capital investment and provides approximately $\$ 1.8$ million in annual land lease payments (American Wind Energy Association 2015q). A sixth wind farm, the 103-MW New Wind Creek project, is scheduled to be placed in service in December 2016 (Reuters 2015).

In 2009, West Virginia passed an Alternative and Renewable Energy Portfolio Standard that requires certain utilities to derive $25 \%$ of their sales from alternative and renewable energy resources by 2025 (American Wind Energy Association 2015q). In early 2015, West Virginia lawmakers repealed this measure (Sadasivam 2015).

Projects in the state continue to experience wildlife concerns, primarily related to bats. Land use issues regarding mountain top mining impacts in the southern part of the state have also created challenges (Dutton et al. 2014). 


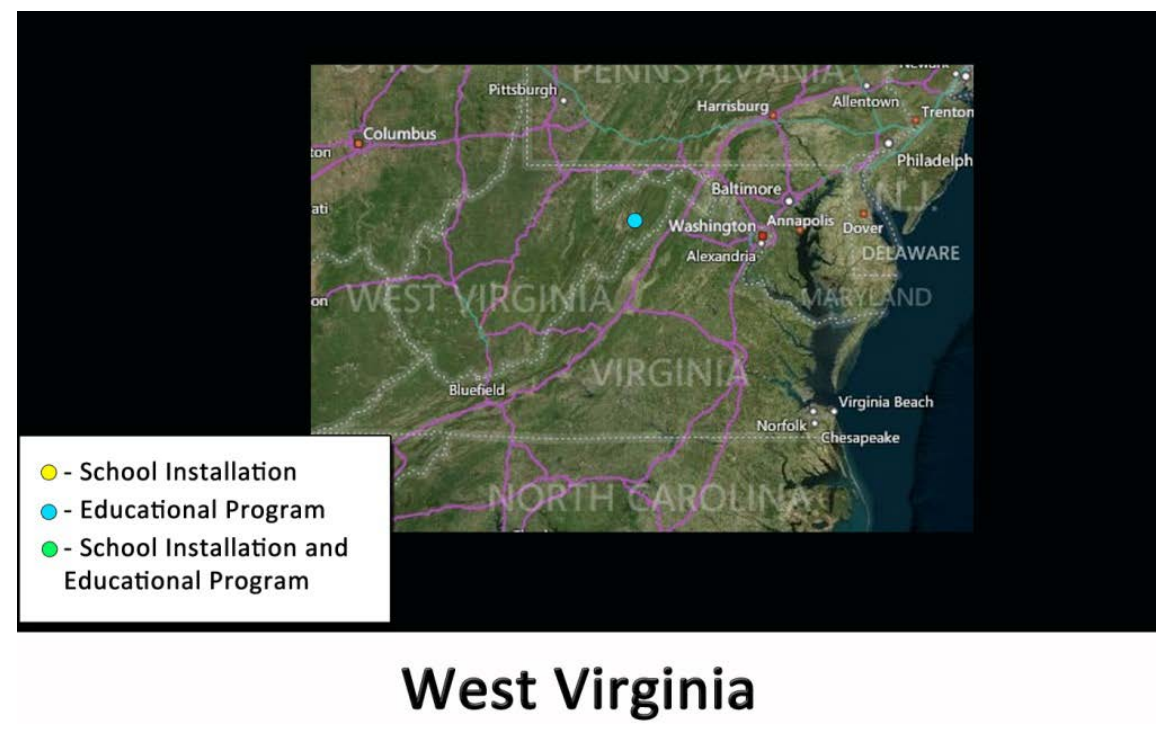

Figure 18. Map of sole school wind educational program in West Virginia

Visit the WINDExchange website ${ }^{57}$ for information about school wind projects and educational programs in West Virginia and other states.

${ }^{57}$ http://apps2.eere.energy.gov/wind/windexchange/schools/ 


\section{References}

American Wind Energy Association. 2015a. "Arizona Wind Energy.” Accessed February 16, 2016. http://awea.files.cms-plus.com/FileDownloads/pdfs/Arizona.pdf

American Wind Energy Association. 2015b. "California Wind Energy." Accessed February 11, 2016. http://awea.files.cms-plus.com/FileDownloads/pdfs/California.pdf

American Wind Energy Association. 2015c. "Colorado Wind Energy." Accessed February 16, 2016. http://awea.files.cms-plus.com/FileDownloads/pdfs/Colorado.pdf

American Wind Energy Association. 2015d. "Kansas Wind Energy." Accessed February 11, 2016. http://awea.files.cms-plus.com/FileDownloads/pdfs/Kansas.pdf

American Wind Energy Association. 2015e. "Massachusetts Wind Energy." Accessed February 7, 2016. http://awea.files.cms-plus.com/FileDownloads/pdfs/Massachusetts.pdf

American Wind Energy Association. 2015f. "Nebraska Wind Energy." Accessed February 11, 2016. http://awea.files.cms-plus.com/FileDownloads/pdfs/Nebraska.pdf

American Wind Energy Association. 2015g. "Nevada Wind Energy.”Accessed February 16, 2016. http://awea.files.cms-plus.com/FileDownloads/pdfs/Nevada.pdf

American Wind Energy Association. 2015h. "New Mexico Wind Energy." Accessed February 16, 2016. http://awea.files.cms-plus.com/FileDownloads/pdfs/New\%20Mexico.pdf

American Wind Energy Association. 2015i. "New York Wind Energy.” Accessed February 7, 2016. http://awea.files.cms-plus.com/FileDownloads/pdfs/New\%20York.pdf

American Wind Energy Association. 2015j. "Oklahoma Wind Energy.” Accessed February 11, 2016. http://awea.files.cms-plus.com/FileDownloads/pdfs/Oklahoma.pdf

American Wind Energy Association. 2015k. "Pennsylvania Wind Energy." Accessed February 8, 2016. http://awea.files.cms-plus.com/FileDownloads/pdfs/Pennsylvania.pdf

American Wind Energy Association. 20151. "Texas Wind Energy.” Accessed February 11, 2016. http://awea.files.cms-plus.com/FileDownloads/pdfs/Texas.pdf

American Wind Energy Association. 2015m. U.S Wind Industry Annual Market Report 2014. http://www.awea.org/AMR2014

American Wind Energy Association. 2015n. U.S Wind Industry Third Quarter 2015 Market Report. http://awea.files.cms-

plus.com/FileDownloads/pdfs/3Q2015\%20AWEA\%20Market\%20Report\%20Public\%20Versio n.pdf 
American Wind Energy Association. 2015o. "Utah Wind Energy." Accessed February 16, 2016. http://awea.files.cms-plus.com/FileDownloads/pdfs/Utah.pdf

American Wind Energy Association. 2015p. "Vermont Wind Energy." Accessed February 7, 2016. http://awea.files.cms-plus.com/FileDownloads/pdfs/vermont.pdf

American Wind Energy Association. 2015q. "West Virginia Wind Energy." Accessed February 10, 2015. http://awea.files.cms-plus.com/FileDownloads/pdfs/West\%20Virginia.pdf

American Wind Energy Association. 2015r. "Wyoming Wind Energy." Accessed February 10, 2016. http://awea.files.cms-plus.com/FileDownloads/pdfs/Wyoming.pdf

Boughton, Kathryn. 2015. "Wind Energy Turbines Rising." Republican-American, August 4. http://rep-am.com/articles/2015/08/04/news/local/899126.txt

Brean, Henry. 2015. "Second Golden Eagle Found Dead at Nevada Wind Farm." Las Vegas Review Journal, February 24. http://www.reviewjournal.com/news/water-environment/secondgolden-eagle-found-dead-nevada-wind-farm

Bunch, Joey. 2015. "Colorado House Kills Senate Bill to Rollback Renewable Energy Standard." Denver Post, March 2. http://www.denverpost.com/news/ci 27627209/colorado-house-killsenate-bill-rollback-renewable-energy

California Energy Commission. Wind Energy in California. Accessed February 11, 2016. http://www.energy.ca.gov/wind/

Congressional Research Service. (December 29, 2014). Federal Land Ownership: Overview and Data. https://www.fas.org/sgp/crs/misc/R42346.pdf

DSIRE. Renewable Energy Standard Program Overview, last modified June 16, 2015. http://programs.dsireusa.org/system/program/detail/5786

Dumat-ol Daleno, Gaynor. 2016. "Guam Power Authority Testing First Wind Turbine." Pacific Islands Report, January 12. http://pidp.eastwestcenter.org/pireport/2016/January/01-13-12.htm

Dutton, James; King, Adam; and Catrina Sedgwick. 2014. "Renewable Energy Source for West Virginia is Blowing in the Wind." Mountaineer News Service, February

13. http://mountaineernewsservice.com/renewable-energy-source-for-west-virginia-is-blowingin-the-wind/

Edison International. "Renewable Transmission." Accessed February 11, 2016. https://www.sce.com/NR/rdonlyres/7A4E0141-E3F7-4092-8E143DF6189D211D/0/090318_SCE_Backgrounder_RAP.pdf 
Emmerich, Kevin. 2015. "Conservationists Ask for New Decision on the Searchlight Wind Project." The Ely Times, March 20. http://www.elynews.com/2015/03/20/conservationists-askfor-new-decision-on-the-searchlight-wind-project/

Funk, John. 2015. "Drilling for Wind: LEEDCo Fields International Geotechnical Team 10 Miles Offshore." Cleveland Plain Dealer, September

3. http://www.cleveland.com/business/index.ssf/2015/09/drilling_for_wind_leedco_field.html

Google Blog. 2012. "More Renewable Energy for Our Data Centers.” September

26, https://googleblog.blogspot.com/2012/09/more-renewable-energy-for-our-data.html

Green, Rick. 2015. "Gov. Mary Fallin Signs Oklahoma Wind Energy Bill.” The Oklahoman, May 21. http://newsok.com/article/5420996

Gross, Daniel. 2015. "The Texas Town that Just Quit Fossil Fuels." Slate, March

23. http://www.slate.com/articles/business/the juice/2015/03/georgetown texas_goes_renewable why the town is dropping fossil fuels for.html

Hawaii Clean Energy Initiative. "Governor signs bill setting Hawaii's renewable energy goal at 100\%." Last modified June 9, 2015. http://www.hawaiicleanenergyinitiative.org/governor-signsbill-setting-hawaiis-renewable-energy-goal-at-100/

Justia. (2010). Oklahoma Statute 17 O.S. §

160.14. http://law.justia.com/codes/oklahoma/2014/title-17/section-17-160.14

KOB4. 2015. "Senate Panel Tables renewable Energy Standards Bill." Associated Press, March 17. http://www.kob.com/article/stories/s3738311.shtml\#.VgQhM8tVhBd

Kuffner, Alex. 2015. "Opponents File Challenge to Block Island Wind Farm in Federal Court." Providence Journal, August

17. http://www.providencejournal.com/article/20150817/NEWS/150819383

Laukaitis, Algis J. 2014. "LES Adds Wind, Solar Farms in Major Push to Renewable Energy." Lincoln Journal Star, December 19. http://journalstar.com/news/local/les-adds-wind-solar-farmsin-major-push-to-renewable/article_26876bc7-a083-5747-a6bb-30c8c8044bd3.html

Magill, Bobby. (2014). “Texas Breaks Wind Power Production Record." Climate Central, June 25. http://www.climatecentral.org/news/texas-wind-power-record-17650

Massachusetts Clean Energy Center. (March 26, 2014). "Energy Officials Approve Relief Funding for Falmouth Community Wind Project." http://www.masscec.com/aboutmasscec/news/energy-officials-approve-relief-funding-falmouth-community-wind-project

Mass Energy Consumers Alliance. "Local Wind Turbines, Sources of Green Power for Our Members." Accessed February 7, 2016. https://www.massenergy.org/renewable-energy/wind 
Monies, Paul. 2015a. "Oklahoma Bill Puts Siting Restrictions and Reporting Requirements on Wind Farms.” The Oklahoman, April 1. http://newsok.com/article/5406313

Monies, Paul. 2015b. "Plains and Eastern Clean Line Plans 720-Mile Run through Oklahoma." The Oklahoman, September 13. http://newsok.com/article/5446438

Montoya Bryan, Susan. 2015. "House Votes to Roll Back 2020 Renewable Energy Standard." Associated Press, March 13. http://www.washingtontimes.com/news/2015/mar/13/house-votesto-rollback-2020-renewable-energy-stan/?page=all

Morris, Allie. 2014. "Iberdrola Abandons Wild Meadows Wind Farm, Raising Questions about Future of Wind Power in New Hampshire." Concord Monitor, May

28. http://www.concordmonitor.com/news/nation/world/12150881-95/ibredrola-abandons-wildmeadows-wind-farm-raising-questions-about-future-of-wind-power-in

National Renewable Energy Laboratory. (June 2013). Wind Powering America's Regional Stakeholder Meetings and Priority State Reports. http:/www.nrel.gov/docs/fy13osti/56289.pdf

Navigant Consulting, Inc. 2014. Offshore Wind Market and Economic Analysis 2014: Annual Market Assessment. Prepared for the U.S. Department of Energy. DE-

EE0005360. http://energy.gov/sites/prod/files/2014/09/f18/2014\%20Navigant\%20Offshore\%20 Wind $\% 20$ Market $\% 20 \% 26 \% 20$ Economic\%20Analysis.pdf

Nebraska Energy Office. Wind Energy Generation in Nebraska. Last modified February 4, 2016. http:/www.neo.ne.gov/statshtml/89.htm

Nebraska Public Power District. NPPD Announces Final R-Project Transmission Line Route. Last modified January 26, 2015. http://www.nppd.com/2015/nppd-announces-final-r-projecttransmission-line-route/

New Mexico Energy, Minerals and Natural Resources Department. (February 2015.) Economic Analysis of the New Mexico Renewable Energy Production Tax

Credit. http://www.emnrd.state.nm.us/ECMD/CleanEnergyTaxIncentives/documents/REPTCFin alReportFeb2015.pdf

New York State Energy Research and Development Authority. New York Renewable Portfolio Standard. Accessed February 11, 2016. http://www.nyserda.ny.gov/About/Renewable-PortfolioStandard

Omaha Public Power District. (2015a). "OPPD Board Approves Work to Support Midwest Transmission Project,” August 14. http://www.oppd.com/news-resources/newsreleases/2015/august/oppd-board-approves-work-to-support-midwest-transmission-project/

Omaha Public Power District. (2015b). "OPPD to Work with New Developer on Largest Wind Development in Nebraska," April 30. http://www.oppd.com/news-resources/news- 
releases/2015/april/oppd-to-work-with-new-developer-on-largest-wind-development-innebraskal

Pennsylvania Department of Environmental Protection. Budget Testimony of Acting Secretary Quigley, Governor's Proposed 2015-2016 General Fund Budget House Appropriations Budget Hearing: March 11,

2015. http://www.pabudget.com/Display/SiteFiles/154/Documents/FY\%202015-

16\%20GF\%20Budget/Hearings/Written\%20Submitted\%20Testimony/DEP\%20Testimony.pdf

Pennsylvania Public Utility Commission 2016. Pennsylvania Alternative Energy Portfolio Standard Program. Accessed February 7, 2016. http://www.pennaeps.com/aboutaeps/

Preedom, Matthew. 2015. "Wind Turbines: Do Property Values Fall?” Milton Independent, August 27. http://www.miltonindependent.com/wind-turbines-do-property-values-fall/

Proctor, Cathy. 2015. "Federal Judges Rule on Colorado's Renewable Energy Mandate.” Denver Business Journal, July

14. http://www.bizjournals.com/denver/blog/earth to power/2015/07/federal-judges-rule-oncolorados-renewable-energy.html?surround $=\mathrm{etf} \&$ ana $=\mathrm{e} \_$article

Reuters. 2015. "Enbridge Acquires 103-Megawatt West Virginia Wind Project." November 25. http://www.reuters.com/article/idUSnCCN6wb1mp+1c0+MKW20151125

Ring, Wilson. 2015. "Vermont Taking Breather from Wind Power." Burlington Free Press, April 13. http://www.burlingtonfreepress.com/story/news/2015/04/13/vermont-taking-breatherfrom-wind-power/25700545/

Roth, Sammy. 2014. "Wind Energy Faces Turbulent Future in Desert." The Desert Sun, November 25. http://www.desertsun.com/story/money/2014/11/24/drecp-hurt-windmilldevelopments/70059056/

Sadasivam, Naveena. 2015. "In W.Va., New GOP Majority Defangs Renewable Energy Law That Never Had a Bite." Inside Climate News, February

5. http://insideclimatenews.org/news/20150205/wva-new-gop-majority-defangs-renewableenergy-law-never-had-bite

San Diego Gas \& Electric. "SDG\&E Energizes the Sunrise Powerlink." Last modified June 8, 2012. http://www.sdge.com/newsroom/press-releases/2012-06-18/sdge-energizes-sunrisepowerlink

Seufert, Dan. 2014. "Plug Pulled on \$150M Wind Farm over Unfriendly Political, Regulatory Climate." New Hampshire Union Leader, May

27. http://www.unionleader.com/apps/pbcs.dll/article?AID=/20140527/NEWS05/140529161 
Siders, David. 2015. "Brown Signs Renewable Energy Bill.” The Sacramento Bee, October 7. http://www.sacbee.com/news/politics-government/capitol-alert/article38089830.html

Southern California Edison. Tehachapi Renewable Transmission Project - Construction Update. Last modified December 2014. https://www.sce.com/wps/wcm/connect/0d5c70db-d283-4f5d8a98-89ee7f2ecde2/TRTP_NewsletterQ42014_NLAK_mobile.pdf?MOD=AJPERES

State of Delaware Public Service Commission. 2011. In the Matter of the Application of Delmarva Power and Light Company for Approval of PSC Docket No. 11-362 Qualified Fuel Cell Provider Project Tariffs. http://depsc.delaware.gov/orders/8079.pdf

Teague, Michael. 2015. "Fossil-Fuel-Rich Oklahoma Digs into Wind Energy." North American Windpower, January. http://nawindpower.com/online/issues/NAW1501/FEAT_03_Fossil-FuelRich-Oklahoma-Digs-Into-Wind-Energy.html

U.S. Department of Energy. 2015a. 2014 Distributed Wind Market Report. PNNL-24460. Pacific Northwest National Laboratory (PNNL), Richland, WA (US). http://energy.gov/eere/wind/downloads/2014-distributed-wind-market-report

U.S. Department of Energy. 2015b. Enabling Wind Power Nationwide. DOE/EE1218. http://energy.gov/sites/prod/files/2015/05/f22/Enabling\%20Wind\%20Power\%20Nationwi de 18MAY2015 FINAL.pdf

U.S. Department of Energy. 2015c. 2014 Wind Technologies Market Report. DOE/GO-1020154702. http://energy.gov/eere/wind/downloads/2014-wind-technologies-market-report

U.S. Department of Energy. 2015d. Wind Vision: A New Era for Wind Power in the United States. DOE/GO-102015-4557. http://energy.gov/eere/wind/wind-vision

U.S. Energy Information Administration. June 23, 2014. "Texas Hits New Peak Wind Output." http://www.eia.gov/todayinenergy/detail.cfm?id=16811

Walton, Dan. 2015. "Wind Energy Development Bill Blocked." Lincoln Journal Star, July 16. http://journalstar.com/legislature/wind-energy-development-bill-blocked/article_85f92b837179-52af-8e37-b489d4de3a5a.html

WINDExchange. (2016). Installed Wind Capacity. U.S. Department of Energy. Accessed February 16, 2016. http://apps2.eere.energy.gov/wind/windexchange/wind_installed_capacity.asp

WINDExchange. (2015). Potential Wind Capacity. U.S. Department of Energy. Accessed February 10, 2016. http://apps2.eere.energy.gov/wind/windexchange/windmaps/resource_potential.asp 
Xcel Energy. 2015. 2014 Renewable Energy Standard Compliance

Report. http://www.xcelenergy.com/staticfiles/xe/Regulatory/Regulatory\%20PDFs/2014-

Renewable-Energy-Standard-Compliance-Report.pdf

Van Dam, C.P. "California Offshore Wind Energy: A Personal Vision.” BOEM Offshore Renewable Energy Workshop, July 29-30, 2014.

Virginia Offshore Wind Coalition. 2014. An Evolution

Revolution. http://wind.jmu.edu/offshore/documents/VOWDA\%20Presentation\%20091614.pdf

Wheeler, Timothy B. 2015a. "Planning for Maryland Offshore Wind Project Gets Underway." Baltimore Sun, June 20. http://www.baltimoresun.com/features/green/blog/bs-md-offshore-wind20150619-story.html

Wheeler, Timothy B. 2015b. "Shore Wind Project Scrapped amid Political Roadblocks." Baltimore Sun, April 6. http://www.baltimoresun.com/features/green/blog/bs-md-wind-energyhurdles-20150406-story.html 